\title{
AndHD
}

\section{Uyuşturucu veya Uyarıcı Madde İmal ve Ticareti Yönünden Suça İştirak ${ }^{(*)}$}

\section{Complicity in Crime in the Manufacturing and Trafficking of Drugs or Stimulants}

\author{
Ersin SARE \\ Hâkim \\ Adana Adliyesi
}

Anahtar Kelimeler
Uyuşturucu,
İştirak,
Fail,
Yardım Eden,
Örgüt.

Keywords

Drugs,

Complicity,

Offender,

Aider,

Organization.

\begin{abstract}
Öz
Uyuşturucu ve uyarıcı maddelerin yarattığı zarar ve tehlike, bireylerin de ötesinde ülke halklarını hatta tüm insanlığ 1 tehdit etmektedir. Uyuşturucu veya uyarıcı madde imal ve ticareti suçunu çoğu zaman belli bir grup insanın bir araya gelerek iş birliği içerisinde işlediği bir gerçektir. Hatta uyuşturucu veya uyarıcı madde ihraç ya da ithal etme suçları, genelde ulusal ve uluslararası boyutta örgütlü olarak işlenmektedir. Bu yüzden uyuşturucu veya uyarıcı madde imal ve ticareti yönünden suça iştirak konusu önem arz etmektedir. Cezasının ağır olması nedeniyle suça katkı sağlayanların ne zaman fail ne zaman yardım eden olarak sorumlu olacaklarının tespiti ayrı bir önem taşır. Zira Türk Ceza Kanunu'na (TCK) göre, bir başkasının suç işlemesine yardım eden kişi hakkında hükmolunan ceza indirilmektedir. TCK'nın 188. maddesindeki suç tanımı ve yargı kararları esas alındığında, kullanım amacı dışında, herhangi bir saikle uyuşturucu maddeye temas eden kişilerin fail olarak cezalandırıldığı söylenebilir. TCK'da suçların iştirak halinde işlenmesi genel bir ağırlaştırıcı neden olarak kabul edilmemiştir. Ancak kanun koyucu uyuşturucu veya uyarıcı madde imal ve ticareti suçunun iştirak halinde işlenmesini özel olarak ağırlaştırıcı neden olarak düzenlemiştir.
\end{abstract}

\begin{abstract}
The harm and danger created by drugs and stimulants threaten not only individuals but also the people of the country and even the whole of humanity. It is a fact that a certain group of peopl $\epsilon$ often come together and commit the crime of manufacturing and trading drugs or stimulants. As a matter of fact, the crimes of exporting or importing drugs or stimulants are generally committed nationally and internationally by being organized. Therefore, the issue of complicity in the manufacture and trade of drugs or stimulants is important. It is of particular importance to determine when those who contribute to the crime will be responsible as the principal offender or aider and when they will be responsible since the punishment is heavy. Moreover, according to the Turkish Penal Code, the penal ty to be impose about the person who assists another person to commit offence, is reduced. Based on the definition of crime and judicial decisions in Article 188 of the Turkish Penal Code, it can be said that people who come into contact with drugs by inducement are punished as the principal offender. In the Turkish Penal Code, committing crimes collectively is not accepted as a general aggravating cause. However, the legislator has specifically regulated that the crime of manufacturing and trading drugs or stimulants is committed as an aggravating cause.
\end{abstract}

(*) Araștırma Makalesi.

Hakem denetiminden geçmiştir.

Gönderim Tarihi: 06.09.2021, Makalenin Kabul Tarihi: 06.01.2022. 


\section{GİRIS}

Uyuşturucu $^{1}$ veya uyarıc1 ${ }^{2}$ madde kullanımının bireyler üzerinde olumsuz etkileri bulunmaktadır. Bireyin sağlığı üzerinde olumsuz etkiler yarattığı gibi bireyin suç işleme eğilimini de arttırdığı bilinen bir gerçektir. Zira uyuşturucu veya uyarıcı madde temin etmek için bireylerin yağma veya şiddet içeren başka suçlar işlediklerine sıklıkla tanık olunmaktadır ${ }^{3}$. Bu yüzden uyuşturucu ve uyarıcı maddelerin yarattığı zarar ve tehlike, bireylerin de ötesinde ülke halklarını hatta tüm insanlığı tehdit etmektedir^. Nitekim “Uyuşturucu veya Uyarıcı Madde İmal ve Ticareti (UUMİT)” suçuna Ceza Kanunu'nun "Kamunun Sağlığına Karşı Suçlar” bölümünde yer verilmiştir5. Tüm insanlık yönünden tehdit oluşturması nedeniyle UUMITT suçu bir zarar suçu değil, tehlike suçudur. Başka bir ifade ile fiilin cezalandırılması için mutlak zararlı sonucun ortaya çıkması gerekmez ${ }^{6}$.

Ceza siyaseti gereği, zaman içerisinde uyuşturucu veya uyarıcı madde kullanımının doğrudan ve dolaylı yoldan hapis cezası ile cezalandırılması yerine uyuşturucu veya uyarıcı madde kullananlara ceza dışı tedbirler, mesela tedavi ve denetimli serbestlik tedbirleri, öngörülmeye başlanmıştır ${ }^{7}$. NitekimAvrupaülke lerinde ve diğer bazı ülkelerde uyuşturucu madde kullanımına ilişkin olarak hürriyeti bağlayıcı cezaların kaldırılması, uyuşturucu madde kullanımının Kanun'da suç olmasına rağmen uygulamada görmezden ge linmesi ve adli suç olmaktan çıkarılması yaklaşımlarının bulunduğu ifade edilmektedir ${ }^{8}$. Uyuşturucu veya uyarıcı madde ticareti suç olarak kabul edildiği ve ağır şekilde cezalandırıldığı halde, uyuşturucu veya uyarıcı madde kullanımının yaptırımsız bırakılmasına ilişkin bu yaklaşımlar uyuşturucu veya uyarıcı madde ticareti yönünden Avrupa'yı ve benzer anlayıştaki ülkeleri pazar haline getirmektedir9 .

Zaman içerisinde UUMIT, küresel ölçekte yasa dışı finans kaynağına dönüşmüş, bu suç özellikle yasa dışı organizasyonların ve terör örgütlerinin finans kaynağı sağlamak için başvurdukları önemli bir araç haline gelmiş, hatta bu açıdan UUMIT suçu ile mücadele, belli oranda organize suçlulukla ve terörle mücadele ile paralel yürütülmeye başlanmıştır ${ }^{10}$.

UUMIT kapsamındaki suçları, çoğu zaman belli bir grup insanın bir araya gelip iş birliği içerisinde işlediği bir gerçektirr ${ }^{11}$. Hatta uyuşturucu veya uyarıcı madde ihraç ya da ithal etme suçları genelde, ulusal

1 Y unanca "narke" (uyku) kelimesinden türetilen "uyuşturucu madde" kavramının bazı hallerde maddenin etkisiyle ters olarak kullanıldığı; uyuşturmaktan ziyade keyif veren, tahrik eden, uyanıklık veren maddelerin de uyuşturucu madde kapsamında değerlendirildiği ifade edilmektedir. Bkz. GÜNAL, Yılmaz: Uyuşturucu Madde Suçları, İş Matbaacılık ve Ticaret, Ankara, 1976, s. 7.

2 Günlük hayatta yaygın olarak kullanılan tütün ve kahvenin bu grupta yer aldığı ifade edilmiş ise de (bkz. GÜNAL, s. 17.) "uyarıcı madde" kavramından, "yasal düzenlemelerle yasaklanmış olan ve uyarıcı etki yaratan maddeler”in anlaşılması gerekmektedir.

3 Uyuşturucu madde kullanan kişiler, bu maddeyi temin etmek için gerekli para ya da malvarlığına sahip değilseler maddeyi elde etmek için hırsızlık, gasp, adam öldürme, yaralama vb. gibi toplum düzenini sarsacak nitelikte suçlar işledikleri, özellikle mafya türü yapılanmaların veya terör örgütlerinin, finansman sağlamak için uyuşturucu veya uyarıcı madde imal ve ticareti suçuna karıştıkları ifade edilmektedir. Bkz. SEVDİM, Ali Erdem: Uyuşturucu veya Uyarıcı Madde Imal ve Ticareti Suçu, Seçkin Yayınevi, Ankara, 2014 , s. 105.

4 GÜNAL, s. 59; YOKUŞ SEVÜK, Handan: Türk Ceza Hukuku Özel Hükümler, 2. Baskı, Adalet Yayınevi, Ankara, 2019, (Öze Hükümler), s. 355.

5 Uyuşturucu ve uyarıcı madde ticareti suçunun mağdurunun ülke toplumu olduğu, hatta toplumun da ötesinde başka ülkelerde yaşayan insanların mağdur konumunda olduğu, o halde bu suçların mağdurunun tüm insanlık olduğunu söylemenin yanlış olmayacağı ifade edilmektedir. Bkz. YAŞAR, Osman / GÖKCAN, Hasan Tahsin / ARTUÇ, Mustafa: Yorumlu-Uygulamalı Türk Ceza Kanunu 4. Cilt md. 141-196, 2. Bask1, Adalet Yayınevi, Ankara, 2014, s. 5719-5720.

6 GÜNAL, s. 55-56; SEVDİM, s. 107.

7 GÜNAL, S. 51.

8 Avrupa ülkelerine ilişkin değerlendirme için bkz. PINARCI, Mustafa: Uyuşturucu Sorunu ve Mücadele Politikası, Adalet Yayınevi, Ankara, 2014, s. 57. Uyuşturucu ve uyarıcı maddelerin türüne göre değișkenlik göstermekle birlikte kimi Avrupa ülkelerinde uyuşturucu ve uyarıcı madde kullanımının suç olmaktan çıkarıldığı ve sadece idari yaptırıma bağlandığı, kimi ülkelerde ise yasal zemine oturtturula rak belli koşullarda uyuşturucu ve uyarıcı madde kullanımına izin verildiği ifade edilmektedir. Bkz. PINARCI, s. 59-61. "Hollanda ve Belçika uyuşturucu kullanmanın serbest olduğu, uyuşturucu bulundurmanın da adli suç olmadı̆̆ iki ülkedir." Bkz. PINARCI, S. 66.

9 Avrupa'ya pazarlanan esrar maddesinin Fas üzerinden İspanya'ya ve oradan tüm Avrupa'ya dağıtıldığı, kokain maddesinin ise Güney Amerika'da üretilerek İspanya, Hollanda, Portekiz ve Belçika kanalıyla Avrupa'ya sokulduğu, eroin maddesinin büyük bir bölümünün ise Afganistan'da üretilip Türkiye üzerinden geçirilerek Avrupa'ya giriş yaptığı ifade edilmektedir. Nitekim 2010 yılında Avrupa'da yakalanan $19.000 \mathrm{~kg}$ eroinin 2/3'lük dilimi olan $12.700 \mathrm{~kg}$ eroinin Türkiye tarafindan yakalandığı belirtilmektedir. Bkz. PINARCI, s. 64-69.

10 ÖZBEK, Veli Özer / DOĞAN, Koray / BACAKSIZ, Pınar / TEPE, İlker: Türk Ceza Hukuku Özel Hükümler, 13. Baskı, Seçkin Yayıne vi, Ankara, 2018, s. 773.

11 Uygulayıcılar tarafından, uyuşturucu ve uyarıcı madde suçlarının, çoğu zaman birden fazla kişi tarafından gerçekleştirildiği, özellikle UUMIT suçunun, neredeyse tek kişi tarafından işlendiğine rastlamanın mümkün olmadığı ifade edilmektedir. Bkz. AKKAYA, Çetin: Uyuşturucu ve Uyarıcı Madde Suçları, 2. Baskı, Adalet Yayınevi, Ankara, 2013, s. 75; YAŞAR / GÖKCAN / ARTUÇ, s. 5763. 
ya da uluslararası sahada faaliyet gösteren suç örgütlerince işlenmektedir ${ }^{12}$. Bu yüzden suça iştirak şartla rının belirlenerek kişilerin ne zaman bu suça iştirak etmiş olacaklarının ve Kanunumuzda fail-yardım eden ayrımı yapılması, suça yardım eden olarak iştirak eden kişinin daha az ceza alması dikkate alındığında hangi sanığın suçtan hangi derecede sorumlu olacağının tespiti önem arz etmektedir.

Çalışmamızda UUMITT suçuna iştirak konusunu inceleyeceğiz. Ancak esas konumuza geçmeden önce Türk Ceza Kanunu'nun (TCK) 188. maddesinde düzenlenen uyuşturucu veya uyarıcı madde imal ve ticareti suçunun maddi, manevi ve hukuka aykırılık unsurları yönünden açıklama yapma gereği duymaktayız. Zira bir suça iştirakten söz edebilmek için öncelikle Kanun'da düzenlenen tipe uygun, hukuka aykırı ve kasten işlenmiş bir eylemin varlığı gerekmektedir.

\section{5237 SAYILI TCK'NIN 188. MADDESINNDE DÜZENLENEN UYUSTTURUCU VEYA UYARICI MADDE IMMAL VE TICARETI SUÇU}

TCK'nın 188. maddesinin 1, 3 ve 7. fikralarında UUMİT suçu yönünden suç teşkil eden hareketlere yer verilmiş; 4,5 ve 8 . fikralarda bu suçun ağırlaştırıcı nedenlerine ve 6 . fikrada hafifletici nedene, 2. fikra da da özellik göstermesi nedeniyle cezanın mahsubuna ilişkin özel bir düzenlemeye yer verilmiştir.

UUMITT suçu esas olarak TCK'nın 188. maddesinin 1 ve 3 . fikralarında düzenlenmiştir ${ }^{13}$. İlgili düzenlemelere bakıldığında uyuşturucu veya uyarıcı maddenin tanımına yer verilmemiş ve hangi maddelerin bu kapsamda olduğu özel olarak belirtilmemiştir ${ }^{14}$. Y alnızca yakalanan uyuşturucu maddelerin TCK'nın 188/4-a hükmünde sayılan maddelerden birinin kapsamına girmesi durumu ağırlaştırıcı neden olarak kabul edilmiştir ${ }^{15}$. Uyuşturucu ve uyarıcı madde tanımının yapılması ve soyut olarak uyuşturucu ve uyarıcı maddelerin neler olduğunun teker teker sayılarak Kanun'da belirtilmesi kişi özgürlüklerini korumak bağlamında faydalı olabilecektir ${ }^{16}$. Bununla birlikte günden güne yeni uyuştur rucu ve uyarıcı maddelerin ortaya çıkması ve etkilerinin de birbirinden farklı olması nedeniyle uyuşturucu ve uyarıcı maddelere tanımlama ya da sayma yoluyla kanunda yer verme işlevsel değildir ${ }^{17}$. Ya kalanan hangi türden maddelerin cezalandırmayı gerektirdiğinin tespiti sorunu, uyuşturucu ve uyarıcı olarak kabul edilen maddeleri sayma yoluyla belirten uluslararası sözleşmeler ${ }^{18}$, iç hukuk düzenlemeleri ${ }^{19}$ ve idarenin kanuna dayanarak bu alanda çıkardığı düzenleyici işlemler ${ }^{20}$ esas alınarak çözümlen-

12 HAFIZOĞULlARI, Zeki / ÖZEN, Muharrem: Türk Ceza Hukuku Özel Hükümler Topluma Karşı Suçlar, 3. Baskı, US-A Yayıncılık, Ankara, 2017, (Topluma Karşı Suçlar), s. 95.

13 Kazanç gütme amacı olmadan uyuşturucu veya uyarıcı maddenin bir başkasına verilmesinin de suç olarak kabul edildiği göz önünde bulundurulduğunda, madde başlığının “Uyuşturucu veya Uyarıcı Madde İmal ve Temini” şeklinde olmasının daha yerinde olacağı ifade edilmektedir. Bkz. SEVDIMM, s. 119-120.

14 Kanunun 188. maddesinin 1. ve 3. fikralarındaki düzenlemelerin yapısı itibariyle eksik ceza normu olduğu, hükümde yer alan uyuşturucu veya uyarıcı madde, ruhsat, ruhsata aykırılık, imal, ithal, ihraç gibi terimlerin anlamlarının, kapsamlarının ve sınırlarının, kanunilik ilkesinin gereği olarak ulusal kanunlar ve ülkenin taraf olduğu uluslararası sözleşmeler esas alınarak belirleneceği ifade edilmektedir. Bkz. HAFIZOĞULLARI / ÖZEN, Topluma Karşı Suçlar, s. 94.

15 Her geçen gün yeni bir uyuşturucu veya uyarıcı maddenin ortaya çıktığı, hatta ortaya çıkan bu maddelerden bazılarının ilgili maddede sayılanlardan daha tehlikeli olduğu, bu nedenle uyuşturucu veya uyarıcı madde ticareti suçunu ağırlaştıran neden açısından sayma yönterninden vazgeçilmesi ve maddenin türüne göre cezanın ağırlaştırılmasının hâkimin takdirine bırakılması gerektiği ifade edilmektedir. BkZ. ÖNER, Mehmet Zülfü: Türk Ceza Hukukunda Uyusturucu veya Uyarıcı Madde Imal ve Ticareti Suçlart, Adalet Yayınevi, Ankara, 2011, s. 158. Morfin maddesinin yasaya aykırı ticaretinin de bu fikra kapsamında ağırlaştırıcı neden olarak kabul edildiği, ancak morfin maddesinin reçete ile temin edilebileceği ve bu nedenle aynı zamanda TCK'nın 188/6 hükmünde düzenlenen hafifletici neden kapsa mında olduğu, aynı maddeye ilişkin olarak hem ağırlaştırıcı nedenin hem de hafifletici nedenin kabul edilmesinin yerinde olmadığı ifade edilmektedir. Bkz. ÖNER, s. 161.

16 SOYASLAN, Doğan: Ceza Hukuku Özel Hükümler, 13. Baskı, Yetkin Yayınları, Ankara, 2020, (Öze Hükümler), s. 487; GÜNAL, s. 13.

17 GÜNAL, S. 64-65.

18 Türkiye, “1961 tarihli Uyușturucu Maddelere Dair Tek Sözleșmesi”nin, “1971 tarihli Psikotrop Maddeler Sözleșmesi”nin ve “1988 tarihli "Uyuşturucu ve Psikotrop Maddelerin Kaçakçılığına Karşı Birleşmiş Milletler Sözleşmesi””nin tarafıdır. Meclis tarafından onaylandığı için Anayasa'nın 90. maddesi gereğince bu sözleşmeler iç hukuk yönünden kanun hükmünde ve değerindedir. Bu nedenle TCK'nın 188. maddesi ile ilgili değerlendirme yapılırken bu sözleşmelerde yer alan hükümlerin dikkate alınması gerektiği ifade edilmektedir. Bkz. SEVDİM, s. 113

19 İç hukukta uyuşturucu veya uyarıcı maddelerin yasaklanması ya da ruhsata bağlanması, 2313 ve 3298 sayılı kanunlar ve bu kanunlara dayanılarak çıkartılan idarenin düzenleyici işlemleri ile sağlanmaktadır.

202313 sayılı Kanun uyarınca uyuşturucu veya uyarıcı nitelik taşıyan maddelerin imal, ithal ve ihracı yönünden sağlık bakanlığından izin alınması gerekmektedir. 2313 sayılı Kanun'un 19. maddesine göre birinci maddede belirtilenlerden hariç uyuşturucu veya uyarıcı nite 
meye çalış1maktadır. Uygulamada yakalanan uyuşturucu ve uyarıcı maddeler ilgili uzmanlık kurumla rına gönderilmekte, uzmanlık kurumu yakalanan maddenin yasaklı uyuşturucu ve uyarıcı maddelerden olup olmadığını tespit etmekte, hâkimler de çoğu zaman bu kurumlarca hazırlanan raporlar doğrultur sunda karar vermektedi liler ${ }^{21}$.

TCK'nın 188. maddesinin 1. fikrasında uyuşturucu veya uyarıcı maddeleri ruhsatsız ya da ruhsata aykırı olarak imal, ithal veya ihraç edenin cezalandırılacağı hüküm altına alınmıştır ${ }^{22}$. İthalden anla şılması gereken, ülkeye başka bir ülkeden uyuşturucu veya uyarıcı madde sokulmasıdır. Ancak bu suçun oluşumu için uyuşturucu veya uyarıcı maddelerin kullanım amacı dışında ülkeye getirilmesi gereklidir $r^{23}$. İhraç; ülkeden, başka bir ülkeye uyuşturucu veya uyarıcı madde gönderilmesidir ve yine bu suçun oluşumu için kullanım amacı dışında bir saikin bulunması gerekmektedir²4.

Başka bir ülkeye uyuşturucu veya uyarıcı madde ihraç edildiğinde, ihraç edilen ülke yönünden ithal suçu oluşacaktır. Kanun koyucu TCK'nın 188/2 maddesini getirerek yabancı ülkede, uyuşturucu veya uya rıcı madde ithali suçundan yapılan yargılama yönünden "ne bis in idem" ilkesine geçerlilik tanınmayacağını kabul etmiştir ${ }^{25}$. Bununla birlikte TCK'nın 188/2 maddesi uyarınca, uyuşturucu veya uyarıcı madde ihracı fiilinin diğer ülke açısından ithal olarak nitelendirilmesi dolayısıyla bu ülkede yapılan yargılama sonucunda hükmolunan cezanın infaz edilen kısmı, Türkiye'de uyuşturucu veya uyarıcı madde ihracı dola yısıyla yapılacak yargılama sonucunda hükmolunan cezadan mahsup edilebilecektir. Böyle bir hüküm getirilerek fail ya da faillerin mükerrer olarak cezalandırılmasının önüne geçilmeye çalışılmıştır.

Imal, tek başına uyuşturucu veya uyarıcı madde olmayan iki veya daha fazla maddenin kimyasal işlemden geçirilerek uyuşturucu madde haline getirilmesi, bir uyuşturucu veya uyarıcı maddenin başka bir uyuşturucu veya uyarıcı maddeye dönüştürülmesi ya da uyuşturucu veya uyarıcı maddelerin saflaştırılması olarak tanımlanmaktadır ${ }^{26}$. Uyuşturucu veya uyarıcı maddenin niteliğinde değişiklik yapmayan işlemler ile doğal şeklinin muhafazası için yapılan işlemlerin imal olarak nitelendirilemeyeceği ifade edilmektedi $r^{27}$. Yüksek Mahkeme esrar maddesinin elde edildiği kenevir bitkisinin, kurutma, toz

likteki maddelerin bu Kanun hükmüne tabi olacağı Cumhurbaşkanı kararıyla Sağlık Bakanlığı tarafindan tayin ve ilan olunur. Bu bağla mada bu alana ilişskin Sağlık Bakanlığının çıkardığı düzenleyici işlemler önem arz etmektedir. 3298 sayılı Kanun'un 1. maddesinin son fıkrasına göre Sağlık Bakanlığının teklifi üzerine tabii ve sentetik nitelikteki uyuşturucu veya uyarıcı maddeler, Cumhurbaşkanlığı kararı ile 3298 sayılı "Uyuşturucu Maddelerle İlgili Kanun" kapsamına dâhil edilebilmektedir.

21 Maddenin niteliğinin tespitinde, kolluk gücü bünyesinde faaliyet gösteren kriminal laboratuvarlar ve Adli Tıp Kurumu 5. Adli Tıp İhtisas Kurulu görev yapmaktadır. Yüksek Mahkemenin vermiș olduğu bir kararda “... bir maddenin TCK'nın 188 ve devamı maddelerinin konusunu oluşturan uyuşturucu ve uyarıcı madde olup olmadiğını belirlemek için, bunun herhangi bir listede yer almasından ziyade, kişinin algılama, muhakeme ve irade yeteneği üzerindeki etkisine bakmak gerekir. Somut bir madde ile ilgili bu bağlamda yapılacak olan değerlendirmenin, ancak bilirkişi (Adli Tıp Kurumu) tarafindan yapılması gerekmektedir.” ifadelerine yer verilmiştir. Bkz. Yargıtay, 10. CD., T. 30.11.2016, E. 2016/2536, K. 2016/3941.

22 Maddenin 1. fikrasında yer alan bu hükmün seçimlik hareketli suç niteliğinde olduğu, imal, ithal veya ihraç hareketlerinden sadece birinin yapılmasının suçun oluşumu için yeterli olduğu, imal, ithal veya ihraç hareketlerinin hepsinin bir arada gerçekleştirilmesi durumunda tek bir suçun oluşacağı ifade edilmektedir. Bkz. YAŞAR / GÖKCAN / ARTUÇ, s. 5724. Suçun seçimlik hareketli suç olmadı̆̆ı, failin uyuşturucu veya uyarıcı madde imal ederek ihraç etmesi durumunda iki ayrı suçun oluşacağını ifade eden yazarlar da bulunmakta dır. Bkz. HAFIZOĞULLARI / ÖZEN, Topluma Karşı Suçlar, s. 93.

23 Bkz. Yargitay, 9. CD., T. 04.06.2015, E. 2015/2214, K. 2015/5655: “... diğer sanı̆̆ın kargo ile gönderdiği kullanma sınırları içinde kalan 12,095 gram uyușturucu maddeyi sanığın aksi sabit olmayan savunmasına göre kullanmak dıșında ticaret amacıyla kabul ettiğine dair delil bulunmadı̆̆g, bu nedenle eyleminin bir bütün halinde kullanmak için uyuşturucu madde kabul etmek suçunu oluşturacağl..."; bkZ. ERMAN, Sahir / ÖZEK, Çetin, Ceza Hukuku Özel Bölüm Kamunun Selametine Karşı İşlenen Suçlar (TCK 369-413), Dünya Yá yıncılık, İstanbul, 1995, s. 268.

24 Bkz. Yargıtay, CGK., T. 13.03.2018, E. 2016/20-426, K. 2018/85: “... söz konusu suçun oluşabilmesi için uyușturucu veya uyarıcı maddenin kullanma dışında bir amaçla yurt dışına çıkarılmış olması gerekmektedir. Bu suç aynı zamanda teşebbüse elverişli olup, sınır kapısı olan yerlerde gümrük görevlilerine beyanda bulunduktan sonra ancak ülke sinırı geçilmeden önce ele geçirilmiş olması halinde biri ihraca teşebbüs, diğer ise TCK'nın 188. maddesinin üçüncü fikrasında düzenlenen tamamlanmış uyuşturucu madde bulundurma ve nakletme ya da sevk etme suçu oluşacaktır.".

25 TCK'nın 188. maddesinin gerekçesinde "Türkiye'den yapılan uyuşturucu veya uyarıcı madde ihracının, karşı ülke açısından ithal fiilini oluşturduğu, bu ülkede uyuşturucu veya uyarıcı madde ithali nedeniyle yargılama yapılması veya bir cezaya mahkûm olunmasının, Türkiye'de uyuşturucu veya uyarıcı madde ihracı dolayısıyla yargllama yapılmasına engel olmadiğl, böylece uyuşturucu veya uyarıcı madde imal ve ticareti suçlartyla ilgili non bis in idem kuralına milletlerarası sahada geçerlilik tanınmadığı" ifade edilmiştir.

26 TEZCAN, Durmuş / ERDEM, Mustafa Ruhan / ÖNOK, R. Murat: Teorik ve Pratik Ceza Özel Hukuku, 17. Baskı, Seçkin Yayınevi, Ankara, 2019, (Ceza Özel Hukuku), s. 907.

27 Bkz. GÜNAL, s. 88; EREM, Faruk: Türk Ceza Kanunu Şerhi Özel Hükümler Cilt: II, Seçkin Yayınevi, Ankara, 1993, s. 1824-1825; YOKUŞ SEVÜK, Özel Hükümler, s. 360. 
haline getirme gibi işlenmiş olmasını imal kapsamında kabul etmemektedir ${ }^{28}$. Bu bağlamda istihsal (üretim) ile imalin birbirinden ayrı tutulduğunu söyleyebiliriz ${ }^{29}$. Bunun yanı sıra topraktan koparılarak kurumaya bırakılan ve kullanım sınırını aşan miktarda esrar elde edilmesi durumunda uyuşturucu veya uyarıcı madde ticareti suçunun, sadece kullanım düzeyinde hint keneviri bitkisinin ekildiği durumlarda 2313 sayılı Kanun uyarınca izinsiz hint keneviri ekmek suçunun oluşacağı; kullanım sınırını aşan miktarda hem dikili vaziyette hem de kurutulmaya bırakılmış esrarın ele geçirilmesi durumunda hem hint keneviri ekmek suçundan hem de TCK'nın 188/3. maddesinde yer alan uyuşturucu veya uyarıcı madde ticareti suçundan ceza verilmesi gerektiği ifade edilmektedir ${ }^{30}$.

TCK'nın 188. maddesinin 3. fikrasında uyuşturucu veya uyarıcı maddeleri ruhsatsız ya da ruhsata aykırı olarak ülke içinde "satan, satışa arz eden, başkalarına veren, sevk eden, nakleden, depolayan, satın alan, kabul eden, bulunduran" kişinin cezalandırılacağı hüküm altına alınmıştır. Satma, bir menfaat ya da bedel karşılı̆g 1 uyuşturucu veya uyarıcı maddenin bir başkasına verilmesidir ${ }^{31}$. Satışa arz etme, uyuşturucu veya uyarıcı maddelerin satış için hazırlanmasıdır ${ }^{32}$. Satma hareketi teşebbüs aşamasında kaldığında, başka bir ifade ile uyuşturucu veya uyarıcı maddenin zilyetliğinin diğer tarafa geçirilmeden söz konusu maddeler yakalandığında satışa arz etme söz konusu olacak ve yine tamamlanmış suçtan ceza verilecektir. Başkalarına verme, hangi amaç ve saik ile olursa olsun herhangi bir bedel karşılığı olmaksızın uyuşturucu veya uyarıcı maddenin bir başkasına temin edilmesidir ${ }^{33}$. Kullanım miktarı sınırında uyuşturucu veya uyarıcı maddenin, bedelsiz, hatır veya sair nedenlerle bir başkasına verilmesi hallerinde dahi başkalarına verme şeklindeki uyuşturucu veya uyarıcı madde ticareti suçunun oluşacağı ifade edilmektedir ${ }^{34}$. Nakletme, uyuşturucu veya uyarıcı maddenin bizzat fail tarafindan ülke içerisinde bir yerden başka bir yere taşınmasıdır ${ }^{35}$. Sevk etme, nakilden farklı olarak uyuşturucu veya uyarıcı maddenin fail tarafindan ülke içerisinde, vasıta kullanılarak başka bir yere gönderilmesi$\mathrm{dir}^{36}$. Depolama, uyuşturucu veya uyarıcı maddenin bir yerde muhafaza edilmesini sağlamaktır ${ }^{37}$. Sur

28 Bkz. Yargitay, 10. CD., T. 20.06.2014, E. 2014/3092, K. 2014/4830: “... kenevir sapçık ve yapraklarını kurutup, ufalayarak toz haline getirdiğ $i$ ve bunlardan net 1229 gram esrar elde ettiği anlaşılan sanı̆̆ın eyleminin 'ticaret amacı ile uyuşturucu madde bulundurma' suçunu oluşturduğu gözetilmeden, suç niteliği yanlış değerlendirilerek TCK'nın 188/3 maddesi yerine TCK'nın 188/1. maddesi gereğince hüküm kurulması...”. Tarım yoluyla yetiştirmenin de imal kapsamında değerlendirilmesi gerektiği yönündeki görüş için bkz. ERMAN / ÖZEK, s. 263.

29 UUMITT ile daha etkin mücadele etmek için "üretmek" (istihsal) fiilinin de bu suçun seçimlik hareketlerinden birisi haline getirilmesi önerilmektedir. Bkz. TEKİN, Nurullah: "Uyuşturucu veya Uyarıcı Madde İmal, İthal ve İhraç Etmek ile Satmak, Satın Almak, Kabul Etmek ve Bulundurmak Suçları", Terazi Hukuk Dergisi, 2009, Cilt 4, Sayı 37, s. 109.

30 BkZ. AKKAYA, S. 87-88; SELBES, Ece: Uyuşturucu veya Uyarıcı Madde Imal ve Ticareti Suçu, Adalet Yayınevi, Ankara, 2017, s. 149; YOKUŞ SEVÜK, Handan: Uyuşturucu veya Uyarıcı Madde Kullanılmasına İlişkin Suçlar, Seçkin Yayınevi, Ankara, 2007, (Uyuşturucu veya Uyarıcı Madde Kullanılmasına İlişkin), s. 173.

31 İçinde uyușturucu madde bulunan evini, deposunu, imalathanesini veya nakil vasıtasını satan ya da kiralayan kișinin de buralarda bulunan uyuşturucu maddeyi satmış olduğunun kabulü gerektiği ifade edilmektedir. Bkz. ERMAN / ÖZEK, s. 272. Satılan uyuşturucu maddenin karşılığında başka bir uyuşturucu madde alınması yani trampa hallerinin ya da satma karşılığında menfaat elde edilmesinin mesela uyuşturucu madde karşılığı satın alan kişi ile cinsel birliktelikte bulunulması satma kapsamında değerlendirilecektir. Bununla birlikte Yaşar / Gökcan /Artuç'a göre; fail, uyuşturucu maddeyi cinsel ilişkide bulunma karşılığı vermiş olsa bile, maddi bir karşılık elde etme diğinden, bu eylem başkalarına verme hareketi kapsamında değerlendirilebilir. Bkz. YAŞAR / GÖKCAN / ARTUÇ, s. 5737.

32 Uyușturucu maddeyi satmak için pazarlık etmek, müșteri aramak, anlaşmaya çalıșmak, kaparo almak gibi hareketlerin satışa arz etmek kapsamında değerlendirilebileceği ifade edilmektedir. Bkz. GÜNGÖR, Şener / KINACI, Ali: Öğreti ve Uygulama Boyutu ile Uyuşturucu ve Psikotrop Maddelerle Illgili Suçlar, Yetkin Yayınları, Ankara, 2001, s. 229; YAŞAR / GÖKCAN / ARTUÇ, 2014, s. 5737; PARLAR, Ali / KIZILKAYA, Azmi: Uyuşturucu ve Uyarıcı Madde Suçları, Bilge Yayınevi, Ankara, 2018, s. 36; ÖNER, s. 126.

33 Bkz. ÖNER, s. 127. Failin kendi kişisel kullanımına yetecek kadar uyuşturucu veya uyarıcı madde miktarına sahipken, bunu acıma hissi gibi bir amaç ile vermesi fiili ile uyuşturucu madde kullanan ve acındırarak ya da rahatsız ederek kendisinden uyuşturucu maddeisteyen bir kimseyi başından savmak için bir miktar uyușturucu maddeyi parasız verme fiilinin TCK'nın 188/3 hükmü uyarınca cezalandırılma sının adil olmadığı ifade edilmektedir. Bkz. GÜNAL, s. 108. Ayrıca bkz. YOKUŞ SEVÜK, Uyuşturucu veya Uyarıcı Madde Kullanılmasına İlişkin, s. 166. Ayrıca kullanım sınırındaki uyuşturucu veya uyarıcı maddenin bir başkasına ikram edilerek birlikte kullanılmasının, kast yokluğundan uyuşturucu veya uyarıcı madde ticareti suçunu oluşturmayacağı ifade edilmektedir. Bkz. YAŞAR / GÖKCAN / ARTUÇ, s. 5738; AKKAYA, s. 39.

Bkz. SEVDIM, s. 141

35 Transit rejimine tabi olan ve başka ülkeden gelip ülkemizden zorunlu olarak geçip başka ülkeye gitmekte olan kara araçlarında herhangi bir nedenle arama yapılması sonucu kullanım miktarının üzerinde uyuşturucu veya uyarıcı madde bulunması halinde, söz konusu maddenin yurt içinde bırakılacağı hususunda herhangi bir delil yoksa ithal ya da ihraca teşebbüs suçunun değil nakletme suçunun oluşacağı ifade edilmektedir. BkZ. GÜNAL, s. 92; PARLAR / KIZILKAYA, s. 35.

36 Bkz. Yargitay, 10. CD., T. 08.03.2021, E. 2017/2625, K. 2021/3144: “... sanı̆̆ın, Kırşehir E tipi Kapalı İnfaz Kurumunda hükümlü olarak bulunan kişiye kargo paketi içindeki ayakkabının topuk kısmına gizlenmiş halde, 2,16 gr esrar elde edilebilecek kenevir bitkisini 
çun oluşumu için depolama hareketinin mutlak maddi kazanç sağlamak maksadıyla yapılmasının zorunlu olmadığı ifade edilmektedir ${ }^{38}$. Satın alma, uyuşturucu maddenin, kullanım maksadı olmaksızın bir başkasından satın alınmasıdır ${ }^{39}$. Burada satın alma hareketi bir başkasına uyuşturucu veya uyarıcı madde temini için gerçekleştirilebilir ${ }^{40}$. Faildeki maksat kazanç elde etmek değil; kullanımsa ve fiilin işleniş özellikleri kullanım amacını açıkça gösteriyorsa bu hükmün uygulanması mümkün değildir. Kabul etme, uyuşturucu veya uyarıcı maddenin, kullanım maksadı olmaksızın ve herhangi bir bedel ödenmeksizin kabul edilmesidir ${ }^{41}$. Bulundurma ise kullanma maksadı olmaksızın herhangi bir saik ya da amaçla uyuşturucu veya uyarıcı maddenin, tasarruf imkânı sağlayacak biçimde kişinin hukuki ya da fiili egemenliğinde bulundurulmasıdır ${ }^{42}$. Kişi kullanım amacı ile yanında uyuşturucu veya uyarıcı madde bulunduruyorsa uyuşturucu veya uyarıcı madde ticareti suçu oluşmayacaktır ${ }^{43}$.

Uyuşturucu veya uyarıcı madde imal ve ticareti suçunun tanımlandığı hükümde sayılan hareketlerin bir kısmı esasen uyuşturucu veya uyarıcı madde temin etme suçunun hazırlık ve teşebbüs hareketlerini teşkil etmektedir. Yine bu hareketlerden bazılarının niteliği göz önünde bulundurulduğunda, uyuşturucu veya uyarıcı madde teminine yardım etme niteliğindeki hareketlerin, temin etme suçu gibi cezalandırıldığını ve bu gibi durumlarda kişilerin fail olarak kabul edildiğini söyleyebiliriz. Kanun'da böylesi bir düzenleme yer almasaydı, depolama, nakletme gibi hareketler bu suça yardım etme şeklindeki iştirak türü kapsamında değerlendirilebilecekti. Kanun koyucunun böyle bir yol izleyerek uyuştur rucu veya uyarıcı madde ticareti suçlarının cezasını ağırlaştırdığını söylemek mümkündür ${ }^{44}$.

Uyuşturucu veya uyarıcı madde satan kişi tespit edildiğinde, satıcının elinde daha fazla uyuşturur cu ve uyarıcı madde olabileceği gerekçesiyle evinde ya da uyuşturucu ve uyarıcı maddeyi sakladığı muhtemel yerlerde, yetkili makamın kararıyla arama yapılmaktadır. Arama yapılan yerlerde uyuşturur cu madde ele geçirildiğinde, ayrı ayrı hem satma hem de bulundurma suçlarının oluşup oluşmayacağı sorunu gündeme gelmektedir. Bu suç seçimlik hareketli suçtur ve bu yüzden uyuşturucu veya uyarıc1 maddeyi satma, nakletme, depolama ve satışa arz etme hareketlerinden birinin ya da tamamının bir arada gerçekleştirilmesi halinde sonuç değişmeyecek ve failin tek suç işlediği kabul edilecektir ${ }^{45}$. Ancak satarken yakalanan ile evde ele geçirilen uyuşturucu veya uyarıcı maddenin özdeş olması gerek-

gönderdiği, ceza infaz kurumu görevlileri tarafindan yapılan kontrolde suça konu maddenin yakalandiğı olayda; sanı̆̆ın kullanma amacl dışında, cezaevinde hükümlü olarak bulunan kişiye teslim edilmek üzere uyuşturucu maddeyi bulundurup sevk ettiği anda uyuşturucu madde ticareti suçunun tamamlandığl gözetilmeden...".

37 Bkz. Yargitay, 10. CD., T. 01.07.2014, E. 2014/3248, K. 2014/5067: “... mülkiyeti, babası olan diğer sanı̆̆a ait olup üvey annesi tarafindan getirilen 15 paket halindeki AM-2201 isimli etken madde içeren 19,8 gram uyuşturucu maddeyi alıp kendi evindeki yatağının altına gizlemek suretiyle 'uyusturucu maddeyi depolama' suçunu islediği sabit olan sanığın TCK'nın 188. maddesinin 3. fikrası gereği cezalandırılması...”. Ayrıca bkz. Yargıtay, 10. CD., T. 29.05.2014, E. 2014/2942, K. 2014/4238: “... sanıkların 'uyuşturucu madde ihraç etme' suçlarına iştirak ettiklerine ilişkin, kuşku ve varsayımdan öte delil bulunmadiğg; sabit olan fiillerinin, konteynırlardaki uyuşturucu maddeyi depoya indirmekten ibaret olduğu ve böylece 'ticaret amacılla uyuşturucu madde bulundurma ve depolama' suçunu işledikleri gözetilmeden...".

38 PARLAR / KIZILKAYA, s. 37.

39 Fail tarafından satın alınan uyuşturucu veya uyarıcı maddenin miktarının suçun niteliğini belirlemede önemli olduğu, bununla birlikte kişisel kullanma ihtiyaç sınırını aşmayan miktarda uyuşturucu veya uyarıcı maddenin satın alındığı durumlarda, kişinin kullanım amacı dışında söz konusu maddeleri satın aldığı diğer delillerden anlaşılıyorsa miktar az olsa bile fiilin TCK'nın 191 maddesi kapsamında de ğil, TCK'nın 188/3 hükmü kapsamında olduğunun değerlendirileceği ifade edilmektedir. Bkz. YOKUŞ SEVÜK, Uyuşturucu veya Uyarıcı Madde Kullanılmasına İlişkin, s. 133.

40 Bkz. Yargitay, 10. CD., T. 10.11.2020, E. 2020/16093, K. 2020/7142: “... başka bir şahsa teslim etmek üzere diğer sanıktan suça konu eroini teslim almadan önce, uyuşturucu maddenin ele geçirildiği anlaşıldığından; sanığın fiilinin tamamlanmadığ ve 'ticaret amacılla uyuşturucu madde satın alma veya kabul etme’ suçunun teşebbüs aşamasında kaldığ dikkate alınarak...”. Ayrıca bkz. Yargitay, 10. CD., T. 21.05.2013, E. 2013/5466, K. 2013/4560.

41 Bkz. Yargitay, 20. CD., T. 07.03.2018, E. 2017/6689, K. 2018/1257: “... sanıkların suç konusu uyuşturucu nitelikteki MDMA etkin maddesi içeren haplart ithal ettiğine ya da ithal suçuna iştirak ettiğine ilişkin, kuşkuyu aşan yeterli ve kesin delil bulunmadığı; sabit olan fillerinin, Türkiye'ye getirilmesinden sonra uyușturucu nitelikte MDMA etkin maddesi içeren hapları teslim almaktan ibaret oldu$\breve{g}$ u dikkate alındığında, sanıklar hakkında TCK'nın 188. maddesinin 3. fikrasında düzenlenen 'ticaret amacıla uyuşturucu maddeyi kabul etme' suçu yerine 'uyuşturucu madde ithal etme' suçundan mahkumiyet hükmü kurulmast...".

43 Bkz. YOKUŞ SEVÜK, Uyuşturucu veya Uyarıcı Madde Kullanılmasına İlişskin, s. 142-144; YAŞAR / GÖKCAN / ARTUÇ, s. 5743.

44 BkZ. EREM, S. 1821.

45 GÜNAL, S. 95-96; AKKAYA, s. 46; ayrıca bkz. Yargitay, 10. CD., T. 19.03.2014, E. 2013/13225, K. 2014/1838 (kararı aktaran SELBES, s. 147). 
mektedir ${ }^{46}$. Bununla birlikte evde yapılan aramada özdeş olmayan, farklı bir maddenin ele geçirildiği hallerde dahi tek suçun oluşacağı yönünde Yüksek Mahkeme kararı bulunmaktadır ${ }^{47}$.

Sıklıkla karşılaşı1dığı üzere, uyuşturucu veya uyarıcı madde satan kişi aynı zamanda bu maddeyi kullanmaktadır. Bu gibi durumda hem ticaret hem de kullanmak için uyuşturucu veya uyarıcı madde bulundurma şeklinde iki suçtan değil, sadece ticaret için uyuşturucu veya uyarıcı madde bulundurma suçundan ceza verilmesi gerektiği savunulmaktadır ${ }^{48}$. Ancak uygulamada her iki suçtan ceza verilmektedir ${ }^{49}$.

TCK'nın 188. maddenin 7. fikrasında, uyuşturucu veya uyarıcı madde imal etme suçunun hazırlık hareketi niteliğindeki fiiller müstakil suç olarak cezalandırılmıştır ${ }^{50}$. Bu fikraya göre uyuşturucu veya uyarıcı etki doğurmamakla birlikte, uyuşturucu veya uyarıcı madde üretiminde kullanılan ve ithal veya imali resmi makamların iznine bağlı olan maddeyi ülkeye "ithal eden, imal eden, satan, satın alan, sevk eden, nakleden, depolayan veya ihraç eden" kişi cezalandırılmaktadır ${ }^{51}$.

Uyuşturucu veya uyarıcı madde imal ve ticareti suçu yönünden fail ya da failler suça konu malın uyuşturucu veya uyarıcı madde olduğunu bilmiyorlarsa hataları esaslı kabul edilecek, kast ortadan kalktığından gerçekleştirilen fiil suç oluşturmayacaktır ${ }^{52}$. Yine fail ya da iştirak edenler suça konu uyuşturucu veya uyarıcı maddenin, TCK'nın 188/4-a maddesinde yer alan türden uyuşturucu madde olduğunu bilmiyorlarsa haklarında ağırlaştırıcı neden uygulanmayacaktır ${ }^{53}$.

İlgili hükümlerdeki "ruhsatsız ya da ruhsata aykırı olarak" ifadesinden ${ }^{54}$, Kanun' un çerçevesini belirlediği usule göre izin alınması hallerinde belli türdeki uyuşturucu veya uyarıcı maddelerin imal edilebileceği, temin edilebileceği ya da bulundurulabileceği anlaşılmalıdır. Gerekli izinler alınmış ise suç oluşmayacaktır ${ }^{55}$.

Kastın bilme ve isteme unsurunun yanı sıra faildeki saike önem atfedildiği durumlarda özel kasttın varlığından söz edilecektir ${ }^{56}$. Failin saikinden kaynaklanan özel kast, diğer unsurları aynı olan suç tiplerini birbirinden ayırır ${ }^{57}$, suç olmayan bir fiili suç haline getirebilir ve bazen de bir suçu başka bir suça dönüştürebilir ${ }^{58}$. Nitekim 188. maddenin gerekçesinde, 1. fikrada tanımlanan suçun oluşumu için

46 ÖNER, S. 191.

47 Yargitay, 20. CD., T. 01.12.2015, E. 2015/290, K. 2015/4903: “... Bazı kişilerin uyuşturucu madde ticareti yaptıklarına ilişkin ihbar ve istihbari bilgiler edinilmesi üzerine sivil givimli adli kolluk görevlilerinin sanıktan 0,2 gram AB PINACA etken maddesi içeren uyusturucu madde satın aldıkları, böylece sanığın satmak için uyuşturucu madde bulundurma suçu ve delili elde edilmiş olup 17.09.2014 tarihinde sanı̆̆ın evinde yapılan aramada 1,2 gram AM-2201 etken maddesi içeren uyuşturucu maddeyi, ilk satıştan sonra temin ettiğine ilişkin bir delil de bulunmadığı gözetilmeden sanık hakkında zincirleme suç hükümleri uygulanarak fazla ceza tayini...". BkZ. ERMAN / ÖZEK, s. 277.

49 Bkz. Yargitay, 10. CD., T. 27.02.2020, E. 2014/4430, K. 2020/1411: “... sanıkların sabit olan fiillerinin 'kullanmak için uyușturucu madde bulundurma' suçunu oluşturduğu ve bu suçtan da aynı iddianame ile dava açılarak tedavi ve denetimli serbestlik kararı verildiği gözetilmeden...".

50 SOY ASLAN, Özel Hükümler, s. 494

51 Söz konusu maddenin, uyuşturucu veya uyarıcı maddenin üretilmesini sağlayacak miktarda olması gerektiği, izinsiz ithal ya da imal edilen maddenin miktarı itibariyle uyușturucu veya uyarıcı madde üretmeye elverișli olmadığı durumlarda işlenemez suçun söz konusu olabileceği ifade edilmektedir. Bkz. HAFIZOĞULLARI / ÖZEN, Topluma Karşı Suçlar, s. 104

52 SOYASLAN, Özel Hükümler, s. 489. Uyuşturucu veya uyarıcı madde için ruhsat alınmasına gerek olmadığı ya da ruhsatının olduğu düşüncesiyle hareket edildiği durumlarda da fiil üzerinde hatanın söz konusu olabileceği ifade edilmektedir. Bkz. HAFIZOĞULLARI / ÖZEN, Topluma Karşı Suçlar, s. 96.

53 GÜNAL, S. 103-104; GÜNGÖR / KINACI, S. 467; YOLCU, Ferit: Uyuşturucu veya Uyarıcı Madde İmal ve Ticareti Suçu (TCK m. 188), Adalet Yayınevi, Ankara, 2015, s. 101.

54 Ruhsata aykırılığın, a) uyuşturucu veya uyarıcı maddenin ruhsatta belirtilen madde dışında bir madde olduğu, b) uyuşturucu veya uyarıcı maddenin ruhsatta yazılı olandan fazla olduğu ya da c) ruhsatta verilen izin dıșında başka bir işleme tabi tutulduğu durumlarda söz konusu olacağı ifade edilmektedir. Bkz. TEZCAN / ERDEM / ÖNOK, Ceza Özel Hukuku, s. 917.

55 Hükümetin ruhsata bağladığı uyuşturucu veya uyarıcı maddelere ilişkin izin verme merciin sağlık bakanlığı olduğu, uyuşturucu veya uyarıcı nitelikteki maddenin verilen izin dışında bulunduğu karışımdaki oranının fazla olması ya da ruhsatta belirtilenden başka yerde bulundurulması hallerinde de ruhsata aykırılığın oluşacağı ifade edilmektedir. Bkz. PARLAR / KIZILKAYA, S. 33.

56 DÖNMEZER, Sulhi / ERMAN, Sahir: Nazari ve Tatbiki Ceza Hukuku, Cilt II, 14. Bası, Der Yayınları, İstanbul, 2019 , s. 480.

57 DÖNMEZER / ERMAN, s. 480.

58 TOROSLU, Nevzat: Ceza Hukuku Genel Kısım, 18. Baskı, Savaş Yayınevi, Ankara, 2012, s. 207. 
failde kazanç saikinin, başka bir ifade ile menfaat elde etme saikinin, bulunmasının gerekli olduğu; uyuşturucu maddenin kullanılmasının suç olarak düzenlendiği 191. maddenin gerekçesinde de ilgili suçun oluşumu için failde kullanma saikinin bulunmasının gerektiği ifade edilmiştir ${ }^{59}$. Buradan çıkan sonuç kullanım saikinin bulunmasının; satın alma, kabul etme, bulundurma, nakletme gibi hareketler yönünden uyuşturucu veya uyarıcı madde imal ve ticareti suçunu, uyuşturucu veya uyarıcı madde kullanma suçuna dönüştürdüğüdür. Bunun yanında "başkasına verme" şeklindeki hareket yönünden suçun oluşumu için genel kastın varlığı yeterlidir. Yine önemle belirtmeliyiz ki, kullanma saiki ile bulundurmak hariç olmak üzere, yasal olmayan herhangi bir sebeple uyuşturucu veya uyarıcı maddenin bulundurulması hallerinin tümü ticaret suçunu oluşturabilecektir ${ }^{60}$.

TCK'nın 188/3. hükmünde düzenlenen uyuşturucu veya uyarıcı madde ticareti suçunun cezasının on yıldan başladığı, TCK'nın 191/1. hükmünde düzenlenen suçun cezasının ise iki yıldan başladığı dikkate alındığında faildeki saikin tespiti önemlidir ${ }^{61}$. Saik manevi unsura ilişkindir ve fail hangi saik ile hareket ettiğini açıkça beyan etmiyorsa, failin gerçekleştirdiği harekete bakılarak değerlendirme yapılmaktadır. Nitekim Yüksek Mahkeme yakalanan uyuşturucu maddenin ticari saikle mi, yoksa kullanma saiki ile mi bulundurulduğunun tespitine ilişkin birtakım ölçütler geliştirmiştir ${ }^{62}$. Failin saiki tam olarak tespit edilemiyorsa kullanma amaciyla bulundurduğunun kabulü gerekecektir ${ }^{63}$.

\section{UYUŞTURUCU VEYA UYARICI MADDE İMAL VE TİCARETİ SUÇUNA İŞTİRAK}

Kanunda yer verilen suç tipine göre soyut olarak bir tek kişi tarafından gerçekleştirilmesi mümkün olan, niteliği gereği birden fazla kişinin iştirakinin zorunlu olmadığı bir suçu birden fazla kişinin birlikte gerçekleştirmesi halinde suça iştirakten söz edilecektir ${ }^{64}$. Suçun işlenmesi için birden fazla kişinin bir araya gelmesinin suç tipinde şart koşulduğu durumlarda, çok failli suçların varlığından bahsedilecektir ${ }^{65}$.

UUMIT suçu esasen tek bir kişi tarafından işlenmesi mümkün olan suçlardandır. Bununla birlikte TCK'nın 188. maddesinin 3. fikrasında yer verilen ve seçimlik hareketlerden oluşan uyuşturucu veya uyarıcı maddenin satılması ya da başkasına temin edilmesi esasen çok failli suç tipi kapsamına gir-

59 Bkz. TCK'nın 188. ve 191. maddelerinin gerekçesi.

60 Erem'e göre, ticaret saikinin sübutu, suçun oluşumu için şart değildir. Bkz. EREM, s. 1830. Ayrıca bkz. ERMAN / ÖZEK, s. 276.

61 TCK 191/1 hükmünde düzenlenen suçun ilk defa işlenmesi halinde TCK 191/2 hükmü gereğince kamu davasının açılmasının ertelenme sine ve denetimli serbestlik tedbirine hükmedilmektedir. TCK'nın 188 ve 190. maddelerinde belirtilen suçlardan dolayı dava açıldığ ve yapılan yargılama neticesinde isnat edilen fiilin münhasıran 191/1 maddesinde düzenlenen suç kapsamına girdiği anlaşıldığında hükmün açıklanmasının geri bırakılması kararı verilmektedir. Bkz. TCK madde 191/8. olduğunun belirlenmesinde dikkate alınması gereken ve öğreti ile uygulamada da kabul görmüs bazı kriterler bulunmaktadır. Bunlardan ilki; failin bulundurduğu maddeyi başkasına satma, devir veya tedarik etmek hususunda herhangi bir davranış içine girip girmediğidir. İkinci kriter, uyuşturucu maddenin bulundurulduğu yer ve bulunduruluş biçimidir. Kişisel kullanım için uyuşturucu madde bulunduran kimse, bunu her zaman kolaylıkla erişebileceği yerde, örneğin genellikle evinde veya iş yerinde bulundurmaktadır. Buna karşın uyuşturucunun ev veya iş yerine uzakta, çıkarılması güç ve zaman gerektiren depo, măgara, samanlık gibi bir yere gizlenmesi kullanma dışında bir amaçla bulundurulduğunu gösterebilir. Yine, uyuşturucunun çok sayıda özenli olarak hazırlanmış küçük paketçikler halinde olması, her paketçiğin içine hassas biçimde yapılan tartım sonucu aynı miktarda uyuşturucu madde konulmuş olması, uyuşturucu maddenin ele geçirildiği yerde veya yakınında, hassas terazi ve paketlemede kullanılan ambalaj malzemelerinin bulunmast, kullanım dışında bir amaçla bulundurulduğu hususunda önemli bir belirtidir. Üçüncü kriter de bulundurulan uyuşturucu maddenin çeșit ve miktarıdır. Uyuşturucu madde kullanan kimse genelde bir ya da benzer etki gösteren iki değişik uyuşturucu maddeyi bulundurur. Bu nedenle değişik nitelikte ve farkl etkileri olan eroin, kokain, esrar ve amfetamin içeren tabletleri birlikte bulunduran sanığın bunları satmak amacıyla bulundurduğu kabul edilmelidir. Kişisel kullanım için kabul edilebilecek miktar, kişinin fiziksel ve ruhsal yapısı ile uyuşturucu veya uyarıcı maddenin niteliğine, cinsine ve kalitesine göre değişiklik göstermekle birlikte, Adli Tip Kurumunun mütalaalarında esrar kullananların her defasında 1-1,5 gram olmak üzere günde üç kez esrar tüketebildikleri bildirilmektedir. Esrar kullanma alışkanlığı olanların bunlarl göz önüne alarak, birkaç aylık ihtiyaçlarını karşllayacak miktarda esrar maddesini ihtiyaten yanlarında veya ulaşabilecekleri bir yerde bulundurabildikleri de adli dosyalara yansiyan ve bilinen bir husustur. Buna göre, esrar kullanan faillerin olağan sayllan bu süre içinde kişisel olarak kullanıp tüketebilecekleri miktarın üzerinde esrar maddesi bulundurmaları halinde, bulundurmanın kişisel kullanım amacına yönelik olmadığ l kabul edilmelidir.".

Bkz. YOKUŞ SEVÜK, Uyuşturucu veya Uyarıcı Madde Kullanılmasına İlişkin, s. 143; SEVDİM, s. 125-126.

64 PISAPIA, Gian Domenico: İtalyan Ceza Hukuku Müesseseleri Genel Kısım, (Çev.) AKGÜÇ, Atıf, Adalet Bakanlığı Yayınları, Ankara, 1971, s. 204; TOROSLU, s. 295.

65 DÖNMEZER / ERMAN, s. 737. 
mektedir ${ }^{66}$. Zira bu gibi hallerde satıcı ya da temin edenin yanı sira zorunlu olarak alıcı bulunmaktadır ve bu alıcı kişi, tasarruf ehliyetine sahip ise suçun mağduru dahi değildir. Ancak kanun koyucu uyuşturucu veya uyarıcı maddeyi satanı ya da temin edeni cezalandırırken kullanım amacıyla alan kişiyi cezalandırmama tercihinde bulunmuştur ${ }^{67}$. Kanun koyucunun bu tercihi nedeniyle uyuşturucu maddeyi alan kişiyi, azmettiren ya da teşvik eden olarak suça iştirak ettiği gerekçesiyle cezalandırmak mümkün değildir ${ }^{68}$.

Ortaklaşa hareket edilmesi durumunda suçların daha kolay işlendiği, bu gibi durumlarda tehlikenin daha da arttığı bir gerçektir. Bu yüzden suçların ortaklaşa işlenmesinin tercihen genel bir ağırlaştırıcı sebep olarak kabul edilebileceği ifade edilmektedir ${ }^{69}$. Ancak TCK'da suça iştirak, genel bir ağırlaştırıcı sebep olarak düzenlenmemiş, yalnızca belirli suçlar yönünden suç ortaklığı ağırlaştırıcı sebep olarak kabul edilmiştir ${ }^{70}$. Nitekim TCK'nın 188/5. maddesinde uyuşturucu veya uyarıcı madde imal ve ticareti suçunun, "ü̧̈ veya daha fazla kişi tarafindan birlikte işlenmesi ${ }^{71}$ halinde verilecek cezanın yarı oranında, suç işlemek için teşkil edilmiş bir örgütün faaliyeti çerçevesinde işlenmesi halinde verilecek cezanın bir kart arttırılacağı" hüküm altına alınmıştır.

Tipik fiile nedensel katkısı olan herkesin fail gibi cezalandırılmasının savunulması halinde iştirak hükümlerinin, sorumluluğu daraltıc1 etkisinin olduğu söylenebilir ${ }^{72}$. Ancak öğretide genel olarak kabul edilen görüsse göre iştirak hükümlerinin sorumluğu genişletici özelliği bulunmaktadır. Zira iştirak edilen suç tipi esas alındığında, azmettirme ve yardım etme şeklinde gerçekleştirilen hareketler tipik değildir. Başka bir ifade ile azmettiren ile yardım eden konumunda olan kişiler iştirak edilen suça ilişkin tipik hareketlerden hiçbirini gerçekleştirmezler. Ancak Kanun'da ayrıca hüküm bulunması nedeniyle bu iştirak türleri yönünden faillerin sorumluluğuna gidilebilmektedir ${ }^{73}$.

Suça iştirakten söz edebilmek için belli koşulların birlikte gerçekleşmesi gerekmektedir: İştirak edilen suçun icrasına başlanılmış olması, iştirak edilen fiilin kasten gerçekleştirilmiş ve hukuka aykırı nitelikte olması, şerik tarafından gerçekleştirilen hareketin iştirak edilen suça ilişkin harekete nedensel katkısının bulunması, birden çok kişinin birden çok hareketinin bulunması ve suçun bütün ortaklar için aynı olması, suça iştirak iradesinin mevcut olması gerekmektedir. Aşağıda kısaca UUMITT suçu çerçevesinde bu şartlara ilişkin açıklamalarda bulunulacaktır.

\section{A. Suça İștirakin Koșulları}

\section{1. İştirak Edilen Suçun İcra Hareketlerine Başlanılmış, Kasten Gerçekleştirilmiş ve Hukuka Aykırı Olması}

TCK'nın 40. maddesinde bağl1lık kuralı düzenlenmiștir. TCK'nın 40. maddesinin 1. fikrasında "suça iştirak için kasten ve hukuka aykırı işlenmiş bir fiilin varlığ yeterlidir" hükmüne yer verilmiştir.

66 İÇEL, Kayıhan: Ceza Hukuku Genel Hükümler, Beta Yayınevi, İstanbul, 2016, s. 530; DEMIRBAŞ, Timur: Ceza Hukuku Genel Hükümler, 8. Bask1, Seçkin Yayınevi, Ankara, 2012, s. 461.

67 Bkz. SOYASLAN, Doğan: Ceza Hukuku Genel Hükümler, 7. Baskı, Yetkin Yayınları, Ankara, 2016, (Genel Hükümler), s. 503: “... kanunsuz suç ve ceza olmayacağı için alan cezalandırlmayacak sadece satan cezalandırlacaktır.".

68 ERMAN / ÖZEK, s. 293. Ayrıca bkz. ÖNDER, Ayhan: Ceza Hukuku Genel Hükümler Cilt II-III, 2. Bası, Beta Yayınevi, İstanbul, 1992, S. 459: "Bu durumda mağdur olarak görülen zorunlu fail diğer zorunlu faili suça azmettirmiş olsa dahi, yine cezasızlık sebebinden yararlanacaktır.".

69 YÜCE, Turhan Tufan: Ceza Hukukunun Temel Kavramları, Turhan Kitabevi, Ankara, 1985, s. 84.

70765 sayılı TCK'da da aynı durum geçerliydi. Bkz. TANER, Tahir: Ceza Hukuku Umumi Kısım, 3. Basım, İsmail Akgün Matbaası, İstanbul, 1953, s. 529.

71 Kanun'da ilgili suç tiplerinde geçen "birlikte işlenmesi” ifadesinden anlaşılması gerekenin müşterek faillik olduğu ifade edilmektedir. Bkz. ARTUK, Mehmet Emin / GÖKCEN, Ahmet / ALŞAHIN, M. Emin / ÇAKIR, Kerim: Ceza Hukuku Genel Hükümler, 11. Baskı, Adalet Yayınevi, Ankara, 2017, s. 644.

72 “Genis anlamda fail anlayıssına göre; fiilleri ile suc tanımındaki neticeye doğrudan doğruya neden olan tüm kisiller faildir. İstirake ilişsin hükümler sadece her bir ortağın üstlendiği rolle ilgili olarak yaptırımın derecelenmesine hizmet eder. İstirak hükümleri cezalandırmanın alanını daraltıcı rol oynar." bkz. ZAFER, Hamide: Ceza Hukuku Genel Hükümler TCK m. 1-75, 4. Bası, Beta Yayınevi, İstanbul, 2015, s. 413.

73 Toroslu'ya göre iştiraki düzenleyen normun, özel kısımdaki suç yaratan norm ile bir araya gelmesinden, tek failli suç tipinden farklı, yeni birçok failli suç tipi doğar. Kişilerin davranışları, çok failli kanuni tipin kurucu unsurlarına sahip iseler, tek failli suç tipi yönünden tipik olmasalar bile, iştirake ilişkin çok failli kanuni tip yönünden tipik davranışlardır. Bkz. TOROSLU, s. 301-302. 
Bu hükümden, failin hukuka uygun olarak ya da kasıtlı olmadan gerçekleştirdiği fiiller yönünden suça iştirak etmenin mümkün olmadığı anlaşılmaktadır. Bununla birlikte failin kusuru olmadan gerçekleştirmiş olduğu fiiller yönünden suça iştirakin mümkün olduğunu söylemek gerekir. Suça iştirak için failin kusurlu hareketinin aranmamış olması nedeni ile 5237 sayılı TCK'da suça iştirak yönünden slnırlı bağlllık kuralının benimsendiği ifade edilmektedir ${ }^{74}$.

Kanun'da açıkça belirtilmemiş olsa da suça iştirakten söz edebilmek için fail tarafindan gerçekleştirilen fiilin suç tipine uygun olması gerekmektedir ${ }^{75}$. Uyuşturucu veya uyarıcı madde imal ve ticaret suçunun düzenlendiği 188. maddenin 1. ve 3. fikralarında yer alan "ruhsatsız ya da ruhsata aykırı olarak" ifadesi suçun tipikliği ile ilgili bir unsurdur ve ruhsata uygun olarak hareket edilmesi hallerinde hukuka uygunluk nedenin varlığından değil, fiilin tipik olmadığından bahsedilecektir ${ }^{76}$. İzin alınarak ve verilen izne uygun olarak belli türdeki uyuşturucu veya uyarıcı maddelerin imal edilmesi, sa tılması, temin edilmesi ya da bulundurulması hallerinde suç oluşmayacaktır. Zira fiil tipik değildir ve bu durumda suça iştirakte söz konusu olmayacaktır.

İşlenen fiil yönünden hukuka uygunluk hallerinden birinin mevcut olduğu durumlarda söz konusu fiile iştirak edenler cezalandırılmayacaktır. Zira ortada bir suçun varlığından ve dolayısıyla suça iştirakten söz etmek mümkün değildirr7.

Uyuşturucu veya uyarıcı madde imal ve ticaret suçu yönünden zorunluk hali, kanunun hükmünü ve amirin emrini yerine getirme biçiminde hukuka uygunluk nedenlerinin varllğğndan bahsedilebilecektir. Nitekim uyuşturucu madde krizine giren ve bu kriz nedeniyle kendisinin ya da yakınlarının hayatını riske sokan kişiye uyuşturucu madde verilmesinin zorunluluk hali kapsamında değerlendirilebileceği ifade edilmektedir ${ }^{78}$. Bu gibi bir durumda üçüncü kişi lehine zorunluluk hali söz konusudur ${ }^{79}$. Ancak şunu da ifade etmeliyiz ki, TCK'nın 25/2. hükmünde yer verilen zorunluluk halinin kusurluluğu ortadan kaldıran bir neden mi, yoksa hukuka uygunluk nedeni mi olduğuna ilişkin olarak Kanun'da bir kesinlik bulunmamaktadır. Hukuka uygunluk nedeni olduğunun kabulü halinde diğer iştirakçiler de bundan faydal anacak ve gerçekleştirilen fiilden sorumlu olmayacaklardır ${ }^{80}$. Kusurluluğu ortadan kaldıran bir maze ret sebebi olduğunun kabulü halinde ise sadece kurtarma fiilini gerçekleştiren kişi cezalandırılmayacak; suç iştirak eden diğer kişilerin cezai sorumlulukları kendi kusurlarına göre tayin edilecektir ${ }^{81}$.

Aşağıda daha ayrıntılı inceleneceği üzere, UUMITT suçunun işlendiğini açığa çıkarmak için kanuna uygun olarak görevlendirilen ve yine kanunun çizdiği sınırlara ve yetkili makamlarca verilen kararlara uygun olarak hareket eden gizli soruşturmacının da suça iştirakten dolayı sorumlu olmaması gerekir.

74 TAŞKIN KAPUSUZOĞLU, Beril: Suça İştirakte Bağgllık Kural, On İki Levha Yayıncılık, İstanbul, 2017, s. 101. Bağlılık kuralının, sınırlı bağlılık kuralının yanı sıra "asgari bağlılık" kuralı ve "aşırı bağllık kuralı" gibi șekillerinin olduğu, asgari bağl1lık kuralında suça iştirak için tipik bir fiilin gerçekleştirilmesinin yeterli olduğu, aşırı bağılık kuralında ise suça iştirak için fiilin hukuka aykırı olmasının ve kasten işlenmesinin yanı sıra failin kusurlu olmasının arandığı ifade edilmektedir. Bkz. TAŞKIN KAPUSUZOĞLU, 95-104.

75 DEMİREL, Muhammed: Suça İştirakte Bağlllık Kuralı, On İki Levha Yayıncılık, İstanbul, 2017, (Bağlılık Kuralı), s. 365-366. Suç, teşebbüs aşamasında kaldığında hareket esasen tipik değildir, ancak teşebbüs hükmü uyarınca tipiklik sağlanmakta ve fail teşebbüs aşa masında kalan eyleminden cezalandırılmaktadır.

76 DÜLGER, İbrahim: "Uyuş̧urucu veya Uyarıcı Madde İmal ve Ticareti (TCK m. 188)", (Ed.) ÜNVER, Yener / ÖZ, Kerem: Uyuşturucu Madde Suçlarıyla Mücadele, Seçkin Yayınevi, Ankara, 2018, s. 58-59; farklı görüş için bkz. İLTAŞ, Yiğit: Uyuşturucu veya Uyarıcı Madde Imal ve Ticareti Suçu, Adalet Yayınevi, Ankara, 2020, s. 184.

77 DEMIRBAŞ, s. 482

78 YOKUŞ SEVÜK, Uyuşturucu veya Uyarıcı Madde Kullanılmasına İliskin, s. 152-153. Uyușturucu krizine girmiş bir kişiye, hekim tarafindan uyuşturucu madde verilmesi durumunda "kanun hükmünü yerine getirme" biçimindeki hukuka uygunluk nedeninin oluşabile ceği ifade edilmektedir. Bkz. İLTAŞ, s. 185.

79 Uyuşturucu madde krizine giren bir kişinin, uyuşturucu madde temini için suç işlediği hallerde zorunluluk halinden söz edilemeyecektir. Zira tehlikeyi bizzat failin kendisi yaratmıştır. Üçüncü kişi lehine kurtarma fiilini yapan kişi, tehlikeyi kendi yaratmadığından zorunluluk halinden faydalanabilir. Bkz. KANGAL, Zeynel: Ceza Hukukunda Zorunluluk Durumu, Seçkin Yayınevi, Ankara, 2010, s. 348, 473474.

80

KANGAL, s. 209.

81 KANGAL, s. 478. 
UUMITT suçunun kasten gerçekleştirilmiş olması gerekmektedir. İştirak edilen fiil kasten gerçekleştirilmemişse bu suça iştirak etmek mümkün değildir. Kullandığı araçta uyuşturucu ve uyarıcı madde taşındığını bilmeyen şoförün kastı bulunmadığından ve bu nedenle suç iştirak etmiş sayılamayacağından taşıtan kişi yönünden azmettirme değil, dolayısıyla faillik söz konusu olacaktır ${ }^{82}$.

Suça iştirakten söz edebilmek için diğer bir şart iştirak edilen suçun icrasına başlanılmış olunmasıdır. Nitekim TCK'nın 40/3. maddesinde "suça iştirakten dolayı sorumlu tutulabilmek için ilgili suçun en azından teşebbüs aşamasına varmış olması gerekir" hükmüne yer verilmiştir. Başka bir ifade ile iştirak edilen esas suçun hazırlık hareketleri yapılmış, ancak icra aşamasına henüz geçilmemişse iştirak edenleri sorumlu tutmak mümkün değildir.

Teşebbüsün söz konusu olabilmesi için hareketin suç işlemeye elverişli olması gerekmektedir. Nitekim teşebbüs hükmünün düzenlendiği TCK'nın 35. maddesinde "elverişli hareketlerle doğrudan doğruya icraya başlama" ifadesine yer verilmiştir. Suçta kullanılan aracın mutlak elverişsizliğinin yanı sıra maddi konunun mutlak yokluğunda hareketin elverişli olduğundan söz edilemeyecektir ${ }^{83}$ ve bu gibi bir durumda işlenemez suç meydana geldiğinden fail teşebbüsten dahi cezalandırılmayacaktır. Konumuz açısından işlenemez suçun ne gibi hallerde söz konusu olabileceğinin tespiti önemlidir. Zira işlenemez suç söz konusu olduğunda bu fiile iştirak edenler açısından da suç oluşmayacaktır.

Satıldığı tespit edilen maddenin, uyuşturucu veya uyarıcı madde niteliğini haiz olmadığı tespit edildiğinde maddi konunun yokluğu nedeniyle suç da oluşmayacaktır. Ele geçirilen uyuşturucu ve uyarıcı maddenin az miktarda ya da bulaşık durumda bulunması sebebiyle kullanmaya elverişli olma dığı durumlarda dahi işlenemez suç hükümleri uyarınca failin cezalandırılmaması gerektiği ifade edilmektedir ${ }^{34}$. Bununla birlikte madde miktarının az olması veya amaca uygun etki yapıp yapmaması, suçun tehlike suçu olması nedeniyle suçun oluşumunu etkilemez ve bu gibi bir durumda aracın elverişsizliği değil, yetersizliği söz konusudur ${ }^{85}$. Yüksek Mahkeme, başka bir madde ile karışık ya da tek başına, çok az miktarda yasak nitelikte uyuşturucu veya uyarıcı madde içeren, bu yüzden miktarsal analizi yapılamayan madde ele geçirildiğinde ve ayrıca çok az miktardaki bu maddenin 2313 sayılı Kanun'un 1. maddesinde öngörülen miktarın altında olduğu durumlarda suçun maddi konusunun yokluğu nedeniyle işlenemez suçun söz konusu olduğuna dair kararlar vermektedir ${ }^{86}$.

Ele geçirilen maddenin bulaşı nitelikte olması, kabından veya paketinden ayrılamaması ya da miktarının azlığı nedeniyle kişisel kullanıma elverişli olmadığı durumlarda işlenemez suçun varlı̆̆ından söz edilebilecekse de ${ }^{87}$ herhâlde somut olayın özelliğine bakmak gerekecektir. Nitekim suçüstü hallerinde şüpheliler tarafından, yakalanmaması için uyuşturucu veya uyarıcı nitelikteki maddelerin imha edilmeye çalışıldığı olaylarla sıklıkla karşılaşılmakta ve suçun delili olarak çok az miktarda uyuşturucu veya uyarıcı madde ele geçirilebilmektedir. Örnek vermek gerekirse eve kolluk gücünce baskın yapıldığının anlaşılması üzerine, şüpheliler tarafından poşet içerisindeki uyuşturucu veya uya rıcı madde lavaboya ya da tuvalete döküldügü için, kolluk gücü tarafından kullanılmaya elverişli olmayacak düzeyde çok az miktarda uyuşturucu veya uyarıcı madde ele geçirilebilmektedir. Buna benzer hadiselerde, diğer deliller göz önünde bulundurularak ele geçen uyuşturucu veya uyarıcı maddenin kullanmaya elverişli olduğunu kabul etmek en doğru çözüm yolu olacaktır ${ }^{88}$.

\footnotetext{
82 DEMIREL, Bağlılık Kuralı, s. 380.

83 ALACAKAPTAN, Uğur: İşlenemez Suç, Ankara Üniversitesi Hukuk Fakültesi Yayınları, Ankara, 1968, s. 114.

84 Bkz. YAŞAR / GÖKCAN / ARTUÇ, s. 5735-5736; AKKAYA, s. 36.

85 Bkz. ÖNER, S. 122-124; YOKUȘ SEVÜK, Uyuşturucu veya Uyarıcı Madde Kullanılmasına İlişkin, S. 159. Yokuş Sevük tarafindan kullanmak için uyuşturucu veya uyarıcı madde bulundurma suçu için ifade edilen bu görüş, şüphesiz uyuşturucu veya uyarıcı madde ticareti suçu için de geçerlidir.

86 Bkz. Yargitay, 20. CD., T. 12.06.2019, E. 2017/5260, K. 2019/3549; Yargitay, 20. CD., T. 11.12.2018, E. 2015/12447, K. 2018/5870; Yargitay, 10. CD., T. 09.01.2012, E. 2008/3482, K. 2012/34; farklı yönde karar için bkz. Yargitay, CGK., T. 13.02.2020, E. 2016/16871, K. 2020/102.

87 GÜNGÖR / KINACI, s. 213.

88 Bkz. Yargitay, 10. CD., T. 06.03.2007, E. 2006/7517, K. 2007/2633, (karar1 aktaran AKKAYA, s. 36).
} 
Failin cezalandırılmasını engelleyen kişisel nedenlerin bulunması, başka bir ifade ile failin gerçekleştirmiş olduğu kasıtlı ve hukuka aykırı fiilin, failde bulunan kişisel nedenden dolayı cezalandırılmaması, diğer suç ortaklarının cezalandırılmasını engellemez ${ }^{89}$. Örneğin UUMİT suçunu işleyen esas failin yasama ya da diplomasi bağışıklığından faydalanması, diğer suç ortaklarının cezalandırılmasını engellemeyecektir.

\section{2. Şerik Tarafından Gerçekleştirilen Hareketin İştirak Edilen Suça İliş̧kin Harekete Nedensel Katkısının Bulunması}

Suça iştirakten söz edebilmek için gerçekleştirilen icari ya da ihmali hareketin, iştirak edilen suçun meydana gelmesinde nedensel katkısının bulunması gerekmektedir ${ }^{90}$. İștirakçinin fiilinin, suçun gerçekleşmesinin olmazsa olmaz koşulunu oluşturması aranmaz ${ }^{91}$. Şerik tarafindan gerçekleştirilen hareketin suçun işlenmesini desteklemiş, muhtemel hale getirmiş ve suçun işlenme riskini yükseltmiş olması failin sorumlu olması için yeterlidir ${ }^{92}$. Başka bir ifade ile bir ortağın hareketinin eksikliğinden dolayı diğer ortakların hareketlerinde değişiklik olacaksa ortağın hareketinin suç teşkil eden fiil üze rinde etkisi vardır ve dolayısıyla öteki ortaklar ile birlikte suça iştirakten sorumlu olacaktır ${ }^{93}$. Bununla birlikte soyut olarak nedensel değer taşıyan bir hareketin, suçun işlenmesinde hiçbir etkisinin bulunmadığı, suçun işlenme riskini yükseltmediği hallerde suça iştirak ettiği gerekçesi ile bu hareketi gerçekleştiren kişinin sorumluluğuna gidilmemesi gerektiği ifade edilmektedir ${ }^{94}$.

Günlük hayatta yapılması normal kabul edilen tarafsız hareketlerin, suçun işlenmesine nedensel olarak katkı sağlasa da riski attırması yönünden bir değerlendirme yapıldığında yardım etme kapsamında cezalandırılmasının mümkün olmadığı belirtilmektedir ${ }^{95}$. Araç içerisindeki konuşmalardan yolcuların, UUMIT suçunu işlemek için bir yere gittiklerini anlayan taksi şoförünün, bu kişileri istenilen yere ulaştırmasından dolayı yardım eden olarak cezalandırılmaması gerektiği düşünülebilir ${ }^{96}$. Zira failler başka bir taksiyi kullanarak gitmek istedikleri yere ulaşabileceklerdir ${ }^{97}$. Ama suçun uyuşturucu veya uyarıcı madde ticareti değil de terör suçu olduğu kabul edildiğinde, bu değerlendirme pek adil olmayacaktır. Terör saldırısı gerçekleştirecek birisini, saldırının gerçekleşeceği yere götüren ve bu suçun işleneceğini takside bu yolcuyu taşırken öğrenen taksi şoförünün, gerçekleşecek suçtan yardım eden olarak dahi sorumlu olmayacağının kabulü adil bir çözüm değildir. Bununla birlikte taksi şoförür nün, muhakkak olarak kahramanlık gösterip suçun gerçekleşmesini önlemesi gerektiği şeklinde bir kabul de doğru değildir. Bu durumda en azından suçun önlenmesi için makul bir zaman içerisinde kolluk gücünü araması ya da başka tedbirler alması taksi şoförünün yardım eden ve belki de onun da ötesinde müşterek fail olarak sorumlu olmasını bertaraf etmelidir. İhmal suretiyle icrai hareketin şartlarının oluşmadığı ve tarafsız hareketle suça katkı sağlandığı durumlarda suçun önlenmesi yönünden bir yükümlülükten bahsedilmeyecek ise de; bir gerekliliğin var olduğunu kabul etmek gerekir.

89 ZAFER, s. 417.

90 PISAPIA, s. 206

91 ÖZTÜRK, Bahri / ERDEM, Mustafa Ruhan: Uygulamalı Ceza Hukuku ve Güvenlik Tedbirleri Hukuku, 13. Bask1, Seçkin Yayınevi, Ankara, 2013, s. 401: “... failin yardım eden olarak cezalandırllmast için genel olarak asıl fiil bakımından daha uygun bir ön koşulun yaratılmış olması, tipikliği gerçekleştiren davranış̧ kolaylaştırması veya desteklemesi ya da hukuksal yarar üzerinde tehlikeyi yükseltmesi yeterlidir."

92 TOROSLU, s. 311. Suçun işlenme tehlikesini arttıran her fiilin, netice ile nedensel olduğunun kabulü gerektiği ifade edilmektedir. Bkz. ZAFER, s. 419.

93 SOYASLAN, Genel Hükümler, s. 487; HAFIZOĞULLARI, Zeki / ÖZEN, Muharrem: Türk Ceza Hukuku Genel Hükümler, 10. Bask1, US-A Yayıncilık, Ankara, 2017, (Genel Hükümler), s. 333.

94 İÇEL, s. 537

95 EVİ, Vesile Sonay: Suça İştirakte Yardım Edenin Cezai Sorumluluğu, On İki Levha Yayıncılık, İstanbul, 2010, s. 237.

96 Farklı görüş için bkz. HILGENDORF, Eric / VALERIUS, Brian: Alman Ceza Hukuku Genel Kısım, (Çev.) OKTAR, Salih, Yetkin Yayınları, Ankara, 2021, s. 242.

97 Alman Yargıtayının uyuşturucu satııısını satacağı yere götüren şoförü uyuşturucu ticaretine yardım etmeden sorumlu olması gerektiği yönünde karar verdiği nakledilmektedir. Karar ve çevirisi için bkz. EVIK, s. 238. 
Nedensel katkı, suç işlenmeden önce ya da en geç suç tamamlanmadan önce olmalıdır. Suç tamamlandıktan sonra yapılan katkıların suçun işlenmesinde nedensel katkısının olduğunun kabulü mümkün değildir ${ }^{98}$. Dolayısıyla tamamlanmış suça iştirak mümkün değildir ${ }^{99}$.

\section{Birden Çok Kişinin Birden Çok Hareketinin Bulunması ve Suçun Bütün Ortaklar İçin Aynı Olması}

Suça iştirakin bir diğer şartı, fiilin icrasına birden fazla kişinin katılmış olması ve suçun oluşumunda birden fazla fiilin nedensel katkısının bulunmasıdır ${ }^{100}$. Ayrıca gerçekleştirilen suç bütün ortaklar için aynı olmalıdır. Birden fazla kişinin suça nedensel katkısının bulunması, kimin işlenen suçtan sorumlu olacağ 1 ve kimin müşterek fail kimin yardım eden olarak sorumlu tutulması gerektiği sorunur nu ortaya çıkarmaktadır ${ }^{101}$.

İştirak hareketleri maddi ya da manevi nitelikte olabilir. Yine suça iştirak icrai hareketle gerçekleştirilebileceği gibi ihmali hareket ile de gerçekleştirilebilir ${ }^{102}$. Ancak bu durumda da ihmali harekette bulur nan kişinin suçun gerçekleşmesini önleme yükümlülüğü ya da gerekliliği bulunmalıdır ${ }^{103}$. Suçu önleme yükümlülüğü bulunmayan ve işlenen suça herhangi bir şekilde nedensel katkısı olmayan bir kişi, UUMIT suçundan haberdar olup yetkili makamlara ihbarda bulunmamışsa suça iştirak etmiş olmaz ${ }^{104}$, ancak kişinin suçu bildirmeme suçundan sorumluluğu söz konusu olabilir ${ }^{105}$. Bunun yanı sıra suç yerinde olup suçu önleme yükümlülüğü bulunmayan ve hareketsiz kalan kişilerin, sadece orada bulunmaları suçun işlenmesini etkilemiş ise suça iştirak ettiklerinden bahsedilebilecek ${ }^{106}$ ve bu kişilerin böyle bir durumda suçun işlenmesine manevi olarak iştirak etmek suretiyle yardım ettikleri kabul edilebilecektir ${ }^{107}$.

Örnek vermek gerekirse gümrüğe gelen uyuşturucu maddenin yurda sokulmasına göz yuman ya da herhangi bir çevirmede uyuşturucu madde taşıyan aracın geçişine izin veren devlet memurunun hareketi ihmalidir ve uyuşturucu madde ticareti yapma suçuna iştirak etmekten sorumluluğu doğacak$\operatorname{tır}^{108}$. Ancak böyle bir durumda hareket gerçekleştirilmeden önce yapılan bir anlaşmanın varlığ ya da yokluğu farklı sonuçlar doğurabilecektir. Eğer devlet memuru uyuşturucu veya uyarıcı maddeyi yurda sokan veya nakleden kişilerle öncesinde anlaşıp ihmali harekete bulunmuş ise müşterek fail olarak sorumlu olacaktır ${ }^{109}$. Bunun yanında belli suçun failine, haberi olmaksızın ve tek taraflı iradeyle suçun işlenmesine başlanmadan önce veya suçun icrası sırasında yardımda bulunulması müşterek faillik kapsamında değil, yardım etme kapsamında değerlendirilmelidir ${ }^{110}$. Devlet memuru, asıl faillerin haberi olmaksızın tek taraflı irade ile ihmal gösterip uyuşturucu madde taşıyan aracın geçişine izin vermiş ise yardım eden olarak sorumlu olacaktır ${ }^{111}$.

98 HAFIZOĞULLARI / ÖZEN, Genel Hükümler, s. 334.

99 EREM, Faruk / DANIŞMAN, Ahmet / ARTUK, Mehmet Emin: Türk Ceza Hukuku Genel Hükümler, 14. Baskı, Seçkin Yayınevi, Ankara, 1997, s. 377.

100 ZAFER, S. 418.

101 ÖZTÜRK / ERDEM, s. 364.

102 AYDIN, Devrim Türk Ceza Hukukunda Suça İștirak, Yetkin Yayınları, Ankara, 2009, s. 90; HAKERİ, Hakan: "Yeni Türk Ceza Kanunu'nda İş̧irak", Ceza Hukuku Dergisi, 2006, Cilt 1, Sayı 1, (İştirak), s. 76.

103 AYDIN, s. 90; DÖNMEZER / ERMAN, s. 769-770; HAKERİ, Işstirak, s. 76-77.

104 Fail, suçun neticesini önleme konusunda hukuksal bir yükümlülük altındaysa ve bunu önlememişse failin suçu bildirmeme suçundan değil, işlenmesine engel olmadığı suçu ihmali hareketle işlemekten dolayı sorumlu olacağı ifade edilmektedir. Bkz. ERDEM, Mustafa Ruhan: “Suçu BildirmemeSuçu (TCK m. 278)", Türkiye Barolar Birliği Dergisi, 2009, Sayı 80, s. 108.

105 Suçu bildirmeme suçu TCK'nın 278. maddesinde düzenlenmiştir.

106 EREM / DANISSMAN / ARTUK, s. 373.

107 EREM / DANIŞMAN / ARTUK, s. 404.

108 SOY ASLAN, Genel Hükümler, s. 488: “... evin soyulacağın bilen bekçi veya polis memuru ise ve herhangi bir şekilde müdahale ederek suçu önlemiyorsa ihmal suretiyle icra yoluyla suça iştirak ediyor demektir. Çünkü bekçi ve polisin suçu önleme yükümlülüğü vardır.".

109 EREM / DANIŞMAN / ARTUK, s. 391

110 DEMIRBAŞ, s. 473.

111 TCK'nın 37. maddesinin gerekçesinde “... bir suçun failine, onun haberi olmaksızın, tek tarafl iradeyle, suçun işlenmesine başlamadan önce veya suçun icrası sırasında yardım edilmesi halinde, müşterek fail olarak değil, yardım eden olarak sorumlu tutulması gerekir" ifadeleri yer almaktadır. 
Suça iştirak edenler yönünden suçun aynı olması gerekmektedir. Suçun aynı olduğunun kabulü için yalnızca maddi unsurların değil, manevi unsurların da aynı olması gerekmektedir ${ }^{112}$. Suçun olur şumu için özel kast gerekiyorsa, şeriklerde de bu özel kastın mevcudiyeti gerekmektedir ${ }^{113}$.

Farklı ihtimaller dâhilinde suçun farklı olması mümkündür. Suç kararlaştırılandan farklı şekilde işlenmiş olabilir. İşlenen suç daha hafif ya da daha ağır olabilir veya üzerinde anlaşılan suçtan başka ya da ilave bir suç daha işlenmiş olabilirin ${ }^{114}$.

Örnek vermek gerekirse suça iştirak eden kişi nakledilen maddenin tütün olduğunu zannetmektedir. Ancak nakledilen uyuşturucu veya uyarıcı maddedir ya da nakledilen tütünün yanına şerikin irade si dışında uyuşturucu veya uyarıcı madde eklenmiştir. Bu durumda şeriki, uyuşturucu veya uyarıcı madde ticareti suçundan sorumlu tutmak mümkün değildir. Zira üzerinde anlaşılan suçtan başka ya da ilave bir suç işlenmiştir ${ }^{115}$. İşlenen suçun kararlaştırılandan daha hafif ya da daha ağır olması halleri aşağıda "Suça Etki Eden Nedenlerin Diğer Suç Ortaklarına Geçişi” başlığı altında ayrıca incelenmiştir.

Müşterek faillikte suç işleyenlerden biri kararlaştırılan suçun dışına esaslı olarak çıkmışsa diğer suç fa illinin bu sınır aşımı yönünden kastı bulunmadığından sorumlu tutulamayacağı, esasız sapma hallerinde ise diğer suç failinin de bu sınır aşımından sorumlu olması gerektiği ifade edilmektedir ${ }^{116}$. Bu nedenle müşterek faillerden biri, nakledilen uyuşturucu veya uyarıcı maddenin TCK'nın 188/4-a maddesinde sayılan maddelerden olduğunu bilmiyorsa hakkında bu ağırlaştırıcı neden uygulanmayabilecektir ${ }^{117}$.

\section{Suça İştirak İradesinin Bulunması}

Suça iştirakten söz edebilmek için, sadece nedensel değer taşıyan bir hareketin yapılmış olması yetmez; ayrıca suç ortağında iştirak iradesinin bulunması ${ }^{118}$, başka bir ifade ile esas suçu işleme kastının yanı sıra bu suçun işlenmesini mümkün kılan ya da kolaylaştıran bir harekette bulunmayı bilip isteyerek diğer ortakların eylemine katılma iradesinin bulunması gerekir ${ }^{119}$. Buna öğretide iştirakte çifte kast denmektedir ${ }^{120}$. Bununla birlikte suça iştirakten söz edebilmek için suç ortaklarının önceden anlaşmış olmaları ge rekmez ${ }^{121}$. Diğer suç ortaklarının haberi olmadan da bir suçun işlenmesine iştirak etmek mümkündür ${ }^{122}$. İştirak iradesinin suçtan önce ya da en geç suçun gerçekleşmesi sırasında ortaya çıkması gerekmektedir ${ }^{123}$.

Seyahat ettiği özel araçta uyuşturucu madde taşındığını bilmeyen bir kişi ile içinde uyuşturucu madde olduğunu bilmediği kutuyu bir başkasına ulaştıran kuryede uyuşturucu veya uyarıcı madde imal ve ticaret suçuna iştirak etme iradesi bulunmamaktadır ${ }^{124}$.

112 HAKERİ, İstirak, s. 84-85.

113 Farklı görüş için bkz. EVIK, s. 169: "Tipik fiili yapan failin normun aradığı özel kasta sahip olması yeterlidir, bu suça katılan diğer suç ortaklarinin da özel kast ile hareket etmelerine gerek yoktur.".

114 HAKERİ, Ișstirak, s. 85.

115 Bkz. EVIK, s. 180.

116 HILGENDORF / VALERIUS, s. 220.

117 Müşterek faillerden birinin kararlaştırılan suçun sınırını diğer suç ortağından bağımsız olarak ve bilinçli bir şekilde aşması halinde, sınırı aşan kısım bakımından müstakil fail veya duruma göre dolayısıyla fail olarak sorumlu olabileceği ifade edilmektedir. Bkz. ARTUK / GÖKCEN / ALŞAHIN / ÇAKIR, s. 658.

118 ÖZBEK, Veli Özer / DOĞAN, Koray / BACAKSIZ, Pınar: Türk Ceza Hukuku Genel Hükümler, 10. Baskı, Seçkin Yayınevi, Ankara, 2019, s. 518.

119 HAFIZOĞULLARI / ÖZEN, Genel Hükümler, s. 336.

120 Bkz. TAŞKIN KAPUSUZOĞLU, s. 135; DEMIREL, Bağlllık Kurall, s. 429. Suça iştirak edenin, hem failin gerçekleştirmiş olduğu hareketi bilmesi ve istemesi hem de kendi gerçekleștirdiği fiil ile failin gerçekleștirmiş olduğu fiile katkı sağladığını bilmesi ve istemesi gerekmektedir.

121 HAFIZOĞULLARI / ÖZEN, Genel Hükümler, s. 334.

122 Bkz. TCK'nın 37. maddesinin gerekçesi; ayrıca bkz. AYDIN, s. 39.

123 HAKERİ, Hakan, Ceza Hukuku Genel Hükümler, 19. Baskı, Adalet Yayınevi, Ankara, 2016, (Genel Hükümler), s. 547.

124 Aracındaki yolcunun, uyuşturucu veya uyarıcı madde taşıdığını bilmeyen ve bu yolcuyu bir yerden başka bir yere götüren taksi şoförünün iştirakten sorumlu olmaması gerektiği yönünde karar için bkz. Yargıtay, 20. CD., T. 26.12.2019, E. 2018/4546, K. 2019/7605; Yargitay, 9. CD., T. 29.03.2016, E. 2015/1689, K. 2016/3043. 
Failin kasten işlemiş̧ olduğu esas fiile taksirle iştirak etmek mümkün değildir ${ }^{125}$. Ancak olası kast ile suç iştirak etmenin mümkün olduğu belirtilmektedir ${ }^{126}$. Başka ülkelerde yeni bir akım olarak, uyuşturucu madde olma şüphesi bulunan birtakım maddelerin nakledilmesi, reçete edilmesi ve muhafaza edilmesi hallerinde, şüphe edilmesine rağmen gereğinin yapılmaması hallerinin yardım etmek kapsa mında değerlendirildiği ve taksiri bulunan kişilerin cezalandırıldığ ifade edilmektedir ${ }^{127}$.

Bu konuda Yüksek Mahkemenin vermiş olduğu kararlara değinmekte fayda görüyoruz: Kadın sa nık, uyuşturucu veya uyarıcı madde ticareti suçundan ceza alan diğer sanığın eşidir ve olay tarihinde Van'dan İstanbul'a doğru seyahat etmektedirler. İstanbul'da yol uygulamasında araç durdurulmuştur ve araçta 41.000 gram eroin maddesi bulunmuştur. Diğer sanığın eşi olan ve ona refakat eden kadın sanığın, uyuşturucu veya uyarıcı madde ticareti suçuna iştirak ettiğine ilişkin, eşi olan diğer sanığın isteği ve ısrarı üzerine araçta seyahat etmesi dışında her türlü şüpheden uzak, kuşkuyu aşan, yeterli ve kesin delilin bulunmaması nedeniyle Yüksek Mahkeme kadın sanığın beraat etmesi gerektiğine hükmetmiştir ${ }^{128}$. Yüksek Mahkeme başka bir kararında suça konu eroinin aracın özel bölümlerine yapılan zulalarda nakledilmesinin ve kokusunun olmaması nedeniyle sanığın, araçtaki uyuşturucu veya uyarıcı maddeden haberi olmadığına ilişkin savunmasına itibar edilmesi ve bu nedenle beraatine karar verilmesi gerektiğine hükmetmiştir ${ }^{129}$.

Şehirler arasında araç ile uyuşturucu veya uyarıcı madde naklederken yol güzergâhındaki güvenlik güçlerince yapılan kontrolleri daha rahat aşmak için araç içerisindeki kişilerin aile görüntüsü verdiği, böylece daha az şüphe çekildiği ve bu bağlamda aracı kullanan bir erkeğe, yolculuk sırasında bir kadının, hatta çocukların da eşlik ettiği bir gerçektir. Bu gibi bir durumda araçta yolcu olarak bulunan kişinin uyuşturucu maddeden haberi olduğu, başka bir ifade ile iştirak iradesinin bulunduğu, ispat edilebiliyorsa uyuşturucu veya uyarıcı maddenin nakledilmesi yönünden müşterek fail olduğunun kabulü gerekecektir. Bunun birlikte nakil sırasında araçta bulunan uyuşturucu veya uyarıcı madde yolcuya ait değilse ve bu yolcu araçtaki uyuşturucu veya uyarıcı maddeden haberdar ise olayın özelliğine göre yardım eden olarak dahi sorumlu tutulamayacağı yönünde görüşlerin bulunduğunu söylemek gerekir $r^{130}$.

İştirak iradesi, açık bir şekilde ortaya konabileceği gibi, zımni olarak da sergilenebiliriri. Suça iştirak edenin neye katılmakta olduğunu genel hatları ile bilmesi yeterlidir, failin gerçekleştireceği fiilin bütün ayrıntılarını bilmesine gerek yoktur ${ }^{132}$. Nitekim uyuşturucu nakli için gerekli olan aracı kiralayan kişinin suça iştirak ettiğinin kabulü için söz konusu aracın uyuşturucu madde naklinde kullanılacağını bilmesi yeterlidir. Bununla birlikte suçun nasıl gerçekleştirileceğini ve aracın ne şekilde kullanılacağını tüm ayrıntılarıyla bilmesine gerek yoktur. Ayrıca suç ortaklarının önceden birbirleriyle şahsen tanışmış olmaları da zorunlu değildirr ${ }^{133}$.

125 EVIK, s. 170.

126 HAKERİ, İstirak, s. 101.

127 ÜNVER, Yener: "Karşılaştırmalı Hukukta Uyuşturucu Maddeler Konusunda Önemli Hukuki Düzenlemeler”, (Ed.) ÜNVER, Yener / ÖZ, Kerem: Uyuşturucu Madde Suçlartyla Mücadele, Seçkin Yayınevi, Ankara, 2018, s. 35-36.

128 Bkz. Yargitay, CGK., T. 05.11.2020, E. 2017/20-980, K. 2020/448.

129 Yargitay, CGK., T. 12.04.2016, E. 2014/10-75, K. 2016/186.

Demirel, Alman Federal Yüksek Mahkemesinin, son dönemdeki görüşüne göre, fiilin işlenmesine objektif olarak bir katkıda bulunmaksızın fiilin işlenmesi konusunda bilgi sahibi olunmasını veya fiilin işlenmesinin tasvip edilmesini, manevi yardım olarak nitelendirmediğini, bununla birlikte failin, gerek duyduğunda yanında hareketsiz de olsa bekleyen kişinin, lehine olarak olaya müdahale edeceği düşüncesinden hareket etmesi durumunda sorumlu tutulabileceğini, olay yerinde bulunma suretiyle fiilinin tasvip edilmesinin yahut fiilden haberdar olunmasının tek başına cezalandırılabilir yardım etme için yeterli olmadığını ifade ettiğini belirtmektedir. Bkz. DEMIREL, Muhammed: "Alman ve Türk Mahkeme Kararlarında Suçun İşlendiği Yerde Bulunmanın İştirak Açısından Niteliği”, Marmara Üniversitesi Hukuk Fakültesi Hukuk Arașttrmaları Dergisi, 2019, Cilt 25, Sayı 2, Prof. Dr. Ferit Hakan Baykal Armağanı, s. 686-687.

131 HAKERİ, Genel Hükümler, s. 545.

132 ÖNDER, s. 442.

133 ZAFER, s. 419-420. 
UUMITT suçu şüphesi nedeniyle arama yapılan yerlerde bazı zamanlar, şüpheli dışında başkaları da ikamet etmektedir. Bu kişilerin, failin yanı sıra uyuşturucu veya uyarıcı madde bulundurma ya da depolama suçundan sorumlu olup olmayacaklarının tespiti önem taşımaktadır ${ }^{134}$. Öner'e göre uyuştur rucu ve uyarıcı madde satıcısının ilgili maddeleri sakladığı evde yaşayan kişilerin bu maddelerden haberi olmaması durumunda cezalandırılmaları söz konusu değildir, ancak uyuşturucu veya uyarıcı maddeyi birlikte yaşadığı evde saklandığını veya bulundurulduğunu bilen, bulundurulmasına imkân tanıyan ve buna rıza gösteren kişi ya da kişilerin iştirakten sorumlu tutulmaları mümkündür ${ }^{135}$.

Aynı ikametteki kişilerin, suçtan sorumluluğunu daha da daraltan görüşler bulunmaktadır. Nitekim birden fazla kişinin bir aracı veya evi paylaşması halinde, esas failin haricindeki diğer kişi, uyuşturucu maddelerin varlığından haberdar olsa bile bu bilginin kişiyi cezalandırmak için yeterli unsur olmadığ edilmektedir ${ }^{136}$. Bununla birlikte, uyuşturucu veya uyarıcı madde şahsına ait olmamak şartıyla ${ }^{137}$ aynı evi ya da aracı paylaşan kişi ya da kişiler uyuşturucu veya uyarıcı maddeden haberdarlarsa ve bu kişi ya da kişiler bulundukları durum itibariyle uyuşturucu veya uyarıcı madde ticareti suçu yönünden kolaylaştırıcı bir işlev görüyorlarsa iştirakten sorumlu tutulmaları mümkündür ${ }^{138}$.

765 sayılı TCK'nın yürürlükte olduğu dönemde asli iştirak ve tali iştirak ayrımı yapılmaktaydı. Asli iştirak da kendi içerisinde asli maddi iştirak ve asli manevi iştirak olarak ayrılmaktaydı. Asli maddi iştirak, bugün yürürlükte olan Ceza Kanunu sisteminde belirtildiği şekliye faillik kavramına karşılık gelmekteydi. Asli manevi iştirak ise azmettirme müessesine karşılık gelmekteydi. Tali iştirak da yine kendi içerisinde maddi ve manevi ayrımına tabi tutulmaktaydı: Tali maddi iştirak hali suç işlemek için araç sağlama şeklindeki yardım etme haline, tali manevi iştirak da suç işlemeye teşvik etme, suç işleme kararını kuvvetlendirme şeklindeki yardım etme hallerine karşlık gelmekteydi. 5237 sayılı TCK' da asli-tali iştirak ayrımı yerine başka kavramlar kullanılarak ceza sorumluluğu yönünden ikililik sisteminin devam ettirildiği söylenebilirr ${ }^{139}$.

TCK'daki suça iştirak hükümlerinin yer aldığı bölüm, Alman Ceza Kanunu'ndan esinlenerek dür zenlenmiş ve yine mehaz Kanun'daki faillik, azmettiren ve yardım eden şeklinde yapılan ayrım esas alınarak düzenleme yapılmıştır ${ }^{140}$. Suça iştirak kavramının, esasen failliği ve şerikliği bir arada ifade eden üst kavram olduğu ifade edilmektedir ${ }^{141}$. Bu yüzden suça iştirak konusunda açıklama yapılırken faillik konusuna değinmek elzemdir. TCK'nın "Faillik” başlıklı 37. maddesinde müşterek faillik ve dolayısıyla faillik kurumları düzenlenmiş; 38. maddede azmettirme ve 39. maddede yardım etme biçimindeki şeriklik türlerine yer verilmiş hem faillik hem de şerikliğin türleri Kanun'un "Suça İştirak" başlıklı bölümünde yer almıştır. Aşağıda kanun sistematiğine bağlı kalınarak uyuşturucu veya uyarıcı madde imal ve ticareti suçu yönünden önce faillik ve failliğin biçimleri olan müstakil faillik, müşterek faillik, dolayısıyla faillik, sonrasında şeriklik türleri olan azmettirme ve yardım etme konularına değineceğiz.

134 Yaşar / Gökcan / Artuç'a göre; bir dairede uyuşturucu bulunmakta ise, o dairenin içinde uyuşturucu olduğunu bilip anahtarı bulunan ve uyuşturur cu üzerinde her an tasarruf imkânı bulunan herkes için bulundurma suçu oluşacaktır. Bkz. YAŞAR / GÖKCAN/ARTUÇ, s. 5743.

135 ÖNER, s. 189; İLTAŞ, s. 212. Ayrıca bkz. YOLCU, s. 139; SELBES, s. 141-142.

136 İngiltere'de uygulamanın bu yönde olduğu ifade edilmektedir. Bkz. SEVDİM, s. 160.

137 Belirtmeliyiz ki “depolama” şeklindeki uyuşturucu veya uyarıcı madde ticareti suçunda söz konusu madde başkasına ait olsa da depola yan kişi yönünden suç oluşabilmektedir ve kişi fail olarak sorumlu tutulmaktadır. Bkz. ÖZDABAKOĞLU, Erdinç Hakan: 5237 Sayılı Türk Ceza Kanunu 'nda Uyuşturucu veya Uyarıcı Madde Suçlarl ve Illgili Mevzuat, Adalet Yayınevi, Ankara, 2007, s. 135-136.

138 İtalyan Yargıtayının uyuşturucu madde bulundurma suçunun failinin yanında bulunan kişinin, bu suça iştirak nedeniyle sorumlu tutulabilmesi için onun varlığının uyuşturucu maddeyi bulunduran açısından bir şekilde hareketini kolaylaştırdığı, uyuşturucu maddeyi saklayabilmesi bakımından kendini güvende hissetmesini sağladığı sonucuna ulaşılması gerektiğine hükmettiği nakledilmektedir. Bkz. EVİK, s. 249.

139 Suça iştirak edenlerin nasıl cezalandırılması gerektiği hususunda başlıca üç sistemin bulunduğu, eşitlik sisteminde her suç ortağının aynı ceza ile cezalandırıldığı, ikililik sisteminde asli faillerin tam ceza ile suça tali olarak iştirak edenlerin ise daha az ceza ile cezalandırıldı$\breve{g}$ 1, cezanın faile göre belirlenmesinde ise failin tehlikeliliğine göre cezadan indirim yapılıp yapılmayacağının hâkimin takdirinde olduğu ifade edilmektedir. Bkz. ZAFER, s. 414-415.

140 DEMIRBAS, s. 466

141 ARTUK / GÖKCEN / ALŞAHİN / ÇAKIR, s. 642. 


\section{B. Faillik}

Olayın gelişimini dizginleyebilme durumda olan kişilerin fail sayıldığı, esasen failliğin üç durumda söz konusu olduğu, suçu bizzat işleyen müstakil failin hareket (fiil) egemenliğine sahip olduğu, suç teşkil eden hareketi üstün bir irade ile yönlendiren dolaylsıyla failin iradeye egemen olduğu, suç teşkil eden hareketi bir başkası ile birlikte gerçekleştiren müşterek failin fonksiyonel egemenliğe sahip oldur ğu ifade edilmektedir ${ }^{142}$. Başka bir ifade ile müstakil faillik, müşterek faillik ve dolayısıyla faillik bir bütün olarak faillik kapsamı içerisinde değerlendirilmektedir. Faillik söz konusu olduğunda TCK'nın 40. maddesindeyer verilen bağlllık kuralının uygulanmasına ihtiyaç duyulmaz ${ }^{143}$.

\section{Müstakil Faillik}

Kanun'da yer alan suç tipleri, çok failli suçları hariç tutarsak, bir kişi tarafından ihlal edileceği göz önünde bulundurularak düzenlenmiştir. Nitekim UUMITT suçunun düzenlendiği TCK'nın 188. maddesinde de "kişi" terimi kullanılmıştır. Kanundaki tipik fiile uygun icra hareketini gerçekleştiren kişi, fail olarak kabul edilmektedir ${ }^{144}$.

UUMİT suçunda fail herkes olabilir, yani suç özgü suç niteliği taşımaz. Ancak TCK'nın 188/8. maddesinde bu suçun tabip, diş tabibi, eczacı, kimyager, veteriner, sağlık memuru, laborant, ebe, hemşire, diş teknisyeni, hasta bakıcı, sağlık hizmeti veren, kimyacılıkla veya ecza ticareti ile iştigal eden kişi tarafından işlenmesi durumunda verilecek olan cezanın yarı oranda arttırılacağı hüküm altına alınmıştır ${ }^{145}$. Bu ağırlaştırıcı nedenin uygulanabilmesi için failin, maddede sayılan bu mesleklerden birinin mensubu olmas1 gerekmektedir.

Tüzel kişiler bir suçun faili olamazlar, ancak suçun işlenmesi nedeniyle özel hukuk bağlamında sorumlu tutulabilirler ${ }^{146}$. UUMIT suçunun ticari şirketler paravan gösterilmek suretiyle işlendiği hadiselerle sıklıkla karşılaşılmaktadır. Nitekim TCK'nın 189. maddesinde, bu konuya ilişkin olarak özel bir düzenlemeye yer verilmiştir. Maddeye göre "uyuşturucu veya uyarıcı madde imal ve ticareti suçunun bir tüzel kişinin faaliyeti çerçevesinde işlenmesi halinde, tüzel kişi hakkında bunlara özgü güvenlik tedbirlerine hükmolunacaktır". Tüzel kişilere ilişkin hangi türden kararlar verilebileceği TCK'nın 60. maddesinde gösterilmiştir ${ }^{147}$.

Bir tüzel kişiliğin UUMIT suçunda kullanıldığı tespit edildiğinde tüzel kişinin yönetim organında bu lunan herkesin bu suçtan peşinen sorumlu olduklarının kabulü doğru değildir. Zira bazı durumlarda, yönetim organında bulunan belli kişilerin, tüzel kişiliği alet ederek, diğer üyelerden habersiz şekilde ya da diğer üyeleri kandırarak bu suçu bireysel olarak işledikleri görülmektedir. Bu nedenle tüzel kişiliğin yönetim organında bulunan kişiler yönünden kolektif bir değerlendirme değil, yönetim organında yer alan her bir kişinin bireysel kusuruna göre değerlendirme yapılıp sorumlu olup olmadıkları tespit edilmelidir ${ }^{148}$.

İstediği neticeyi elde etmek için kendinin yönlendirdiği bir aracı veya hayvanı kullanan kişi de müstakil faildir ${ }^{149}$.

\footnotetext{
142 ÖZTÜRK / ERDEM, s. 366; bu belirleme fiile egemenlik teorisi kapsamında yapılmaktadır. Bu teorinin Maurach'a dayandığı ve Roxin tarafından geliştirildiği ifade edilmektedir. Ayrıca bkz. ARTUK / GÖKCEN / ALŞAHİN / ÇAKIR, s. 649; DEMIRBAŞ, s. 469.

143 AYDIN, S. 135.

144 ÖZBEK / DOĞAN / BACAKSIZ, s. 505

145 Bkz. SOY ASLAN, Genel Hükümler, s. 492: “Böyle bir ă̆ırlatıcı sebebin konulmasının nedeni, ilgili maddede belirtilen meslekleri icra edenlerin mesleki bilgileri gereği bu maddeleri oluşturabilme veya meslekleri gereği uyuşturucu ve uyarıcı nitelikteki bu maddeleri bulundurma ve satma yetkisine sahip olmalıdır. Bu meslekler suçu işlemede kolaylık sağlamakta ve aynı zamanda bu kişiler tarafindan suçun işlenmesi ile mensubu oldukları mesleklere duyulan güven sarsılmaktadır."

146 DÖNMEZER / ERMAN, s. 712-714

147

TCK'nın 60. maddesine göre “1) Bir kamu kurumunun verdiği izne dayall olarak faaliyette bulunan özel hukuk tüzel kişisinin organ veya temsilcilerinin iștirakiyle ve bu iznin verdiği yetkinin kötüye kullanılması suretiyle tüzel kişi yararına işlenen kasıtlı suçlardan mahkûmiyet halinde, iznin iptaline karar verilir. 2) Müsadere hükümleri, yararına işlenen suçlarda özel hukuk tüzel kişileri hakkında da uygulanır. 3) Yukarıdaki fikralar hükümlerinin uygulanmasının işlenen fiile nazaran daha ağır sonuçlar ortaya çıkarabileceği durumlarda, hâkim bu tedbirlere hükmetmeyebilir.".

148 DÖNMEZER / ERMAN, s. 713.

149 ZAFER, S. 422.
} 


\section{Müșterek Fail}

TCK'nın 37/1. maddesine göre "suçun kanuni tanımında yer alan fiili birlikte gerçekleştiren kişilerden her biri fail olarak sorumlu olur". Bu hüküm müşterek failliği tanımlamaktadır ${ }^{150}$.

Müşterek faillikten söz edilebilmesi için birden çok kişinin, işlenen suç yönünden, fiil üzerinde ortak hâkimiyet kurmaları gereklidir ${ }^{151}$. Ayrıca her bir failde suçu birlikte işleme iradesinin bulunması gerekmektedir ${ }^{152}$. Bu irade birliği, açık ya da sonuç doğuracak şekilde örtülü olabilir ve fiilin işlenmesinden önce veya işlenmesi sırasında gösterilebilir. Eğer bu irade birliği yoksa fiili eş zamanlı gerçekleştiren her bir fail, müstakil fail olarak sorumludur ${ }^{153}$. Bu duruma yan yana faillik adı da verilmektedir ${ }^{154}$. Bunun tespiti özellikle TCK'nın 188/5. hükmünde düzenlenen ağırlaştırıcı nedenin uygulanmasında önem taşır. Zira aşağıda daha ayrıntılı olarak değinileceği üzere TCK'nın 188/5. hükmü uyarınca artırım yapılabilmesi için müşterek failler olarak hareket edilmesi gereklidir ve yan yana faillik dur rumlarında bu ağırlaştıııcı neden uygulanmaz.

Fiil üzerinde ortak hâkimiyet kurulup kurulmadığının tespitinde, suça katılan kişilerin suçun icrasında üstlendikleri rollerin ve suçun icrasına bulundukları katkının gösterdiği önem ve zorunluluğun göz önünde bulundurulması gerektiği ifade edilmektedir ${ }^{155}$. Fiil üzerinde hâkimiyet kurmadan hem tipik hareketleri yapanlar hem de tipik hareketlerin yapılması için zorunlu olan, ancak tipik olmayan diğer hareketleri ya panlar anlaşılmalıdır ${ }^{156}$. Bu bağlamda 765 sayılı TCK'da yer verilen zorunlu feri iştirak halleri, yeni Ka nun' daki düzenlemeler dikkatealındığında müşterek faillik kapsamında değerlendirilmelidi ${ }^{157}$.

Müşterek faillerin davranışlarının eşzamanlı olmasının zorunluluk olmadığı, suç yolunun herhangi bir aşamasında müşterek failliğin ortaya çıkabileceği; uyuşturucu ve uyarıcı madde imal ve ticaret suçunu işlemek amaciyla faillerden birinin tarlasında hint keneviri ekip yetiştirmesinin, diğerinin tohumlardan ham uyuşturucu maddeyi üretmiş olmasının, bir diğerinin de uyuşturucuyu paketleyip satmış olmasının müşterek faillik kapsamında olduğu ifade edilmektedir ${ }^{158}$. Zira UUMİT suçu seçimlik hareketli suçtur. Hareketlerden birinin ya da tamamının birlikte gerçekleştirilmesi arasında fark yoktur ve tek suç oluşur. Suç ortaya çıkana kadar bu seçimlik hareketlerden birinin ya da birkaçının farklı kişiler tarafindan gerçekleştirilmesi durumunda müşterek faillikten söz edilmelidir ${ }^{159}$. Uyuşturucu maddeyi bir başka şehre nakleden ile uyuşturucu maddeyi nakledenden alıp bir başkasına temin eden kişiler uyuşturucu madde ticareti suçunda müşterek fail olarak sorumlu olmalıdır. Yine nakledilen uyuşturucu veya uyarıcı maddenin bir başkasına ait olması durumunda taşıyan nakletmeden, maddenin maliki de sevk etmeden ${ }^{160}$ müşterek fail olarak sorumlu tutulmalıdır. Ancak aşağıda değinileceği üzere Yüksek Mahkeme bu konuda farklı görüştedir.

\footnotetext{
150765 sayılı TCK döneminde müşterek failliğin tespiti için "suçu irtikâp etme”" ve "suçu doğrudan doğruya birlikte işleme” şeklinde kriterler getirilmiştir. Uygulamada bu ayrımın bazı güçlüklere neden olduğu, Alman Ceza Kanunu'nda olduğu gibi "suçu birlikte işleyenler fail olarak cezalandırllı"' șeklinde bir hüküm getirilmesinin yeterli olduğu ifade edilmekteydi. Bkz. EREM / DANIȘMAN / ARTUK, s. 391. Nitekim 5237 sayılı TCK'da Alman Ceza Kanunu'na paralel bir şekilde benzer hükme yer verilmiştir.

151 TOROSLU, s. 326; ARTUK / GÖKCEN / ALŞAHIN / ÇAKIR, s. 652.

152 ÖZBEK / DOĞAN / BACAKSIZ, s. 514.

153 HEINRICH, Bernd: Ceza Hukuku Genel Kısım II, (Ed.) ÜNVER, Yener, Adalet Yayınevi, Ankara, 2015, s. 254-255.

154 ÖNDER, S. 460.

155 HAKERİ, Genel Hükümler, s. 559; ARTUK / GÖKCEN / ALŞAHİ / ÇAKIR, s. 654.

156 AYDIN, s. 132.

157 HAFIZOĞULLARI / ÖZEN, Genel Hükümler, s. 346. İstirakçinin hareketi, somut olarak ișlenen suçun ișlenmesine başlamada, ișlenme si esnasında veya sona erdirildikten sonra mutlak zorunlu sayılabiliyorsa, yani genel deney kurallarına göre o hareket olmasaydı öteki ortaklar kanunun suç saydığı fiile kalkışmazlardı denebiliyorsa, yardım etmeden değil, müşterek faillikten söz edileceği ifade edilmektedir. Bkz. HAFIZOĞULLARI / ÖZEN, Genel Hükümler, s. 353. Ayrıca bkz. ÖNDER, s. 470.

158 AYDIN, s. 137.

159 Başka bir seçimlik hareketli suç olan ve TCK'nın 197. maddesinde düzenlenen "para sahteciliği" suçunda, sahte paranın ortaya çıkmasına kadar bir dizi faaliyette bulunanların hepsinin müşterek fail olduğu ifade edilmektedir. Bkz. ARTUK / GÖKCEN / ALŞAHİN / ÇAKIR, s. 655; ÖNDER, s. 460.

160 ÖNER, S. 131.
} 
Yapılan hareketin müşterek faillik kapsamında mı, yoksa yardım eden kapsamında mı olduğu husur su suçun işlenişi üzerinde ortak hâkimiyet kurulup kurulmadığının tespitine göre değişkenlik gösterebilecektir. Ömek vermek gerekirse yüksek risk nedeniyle gözcünün bulunmaması durumunda fiil gerçekleştirilmeyecekse fiil üzerinde ortak hâkimiyet söz konusudur ve bu nedenle gözcü müşterek fail olarak kabul edilebilecektir ${ }^{161}$. Nitekim Yüksek Mahkeme, uyuşturucu veya uyarıcı madde naklederken nakil güzergâhındaki güvenlik güçlerinin yol kontrolünü haber vermek için öncü araçta bulunan fail ya da faillerin yönlendirmesi olmadan, suça konu uyuşturucu maddeyi istenilen yere ulaştırılmasının mümkün olmadığı gerekçesiyle bu kişi ya da kişilerin uyuşturucu veya uyarıcı madde ticareti suçu yönünden müşterek fail olarak kabul edilmesi gerektiğine hükmetmektedir ${ }^{162}$. Aşağılda değinileceği üzere uyuşturucu satımında gözcülük yapanlar ise çoğunlukla yardım eden olarak kabul edilmektedir.

Suçun işlenişinde fiil üzerinde ortak hâkimiyet kurabilmek için suç ortağının, fiilin işlenmesine doğrudan müdahale etmesi ya da suçun işlendiği yerde bizzat bulunmasının gerekmediği, iletişim araçlarıyla fiilin icrasını sevk ve idare edenlerin de müşterek fail olabileceği ifade edilmektedir ${ }^{163}$. Yine suçun planlanmasında esaslı rol oynayanların da müşterek fail olarak kabul edilmesi gerektiği belirtilmektedir ${ }^{164}$. Bu durumda uyuşturucu veya uyarıcı madde kendisine ait olup başka kişileri kulla narak sattıran, naklettiren ya da imal ve ticaretini planlayan kişi de müşterek fail olarak sorumludur.

Özgü suçlarda, suçun birlikte gerçekleştirildiği diğer müşterek failin hem fail hem de özgü suça yardım eden konumunda olduğu, bu gibi bir durumda failliğin şerikliğe asliliği kuralı gereğince sadece faillikten sorumlu olması gerektiği, özgü suçtan sadece bu sıfatı taşıyan kişinin sorumlu olacağı ifade edilmektedir ${ }^{165}$. Bu görüş özellikle UUMITT suçunun ağırlaştırıcı nedeni olan 188/8 hükmünün uygulamasında önem taşrr.

Müşterek faillerden birinin fiili hukuka uygun olsa da bu durum diğer müşterek failleri etkilemez ${ }^{166}$. Bu nedenle UUMITT suçunu gerçekleştirenlerden biri yönünden hukuka uygunluk nedeninin bulunması, diğerlerinin cezalandırılmasını engellemeyecektir.

\section{Dolayısıyla Fail}

TCK'nın 37/2. maddesine göre "suçun işlenmesinde bir başkasını araç olarak kullanan kişi de fail olarak sorumlu tutulur." Bu hüküm dolaylstyla failliği tanımlamaktadır ${ }^{167}$.

Dolayısıyla faillikte isnat yeteneği olmayan, esasen tipik bir fiil gerçekleştirmeyen, hukuka uygunluk sebebi içine sokulan ya da kusuru bulunmayan bir insan, suçun işlenmesinde maddi araç gibi kullanılmaktadır ${ }^{168}$. Başka bir kişinin kullanılması hileli yollarla da gerçekleştirilebilmektedir. Dolay1sıyla faillikte araç olarak kullanılan kişinin cezai sorumluluğu yoktur ve bu gibi hallerde suça iştirakin söz konusu olamayacağ 1 ifade edilmektedir ${ }^{169}$.

Sınırlı bağlılık kuralını kabul etmenin bir sonucu, failin kusurlu olmaksızın gerçekleştirmiş oldur ğu fiile iştirak etmenin mümkün olmasıdır. Bu durumda kusuru bulunmadan hareket eden bir kişiyi azmettirmenin mümkün olduğu söylenebilir. Ancak arka planda yer alan kişi, vasıta olarak kullanılan

\footnotetext{
161 HAKERİ, Genel Hükümler, s. 563; ÖZTÜRK / ERDEM, s. 373.

162 Bkz. Yargitay, CGK., T. 02.04.2013, E. 2012/10-1323, K. 2013/117. Farklı yönde karar için bkz. Yargıtay, 20. CD., T. 23.06.2016, E. 2016/1523, K. 2016/4174.

163 ÖZTÜRK / ERDEM, s. 373; ARTUK / GÖKCEN / ALŞAHİN / ÇAKIR, s. 656; HAKERİ, İstirak, s. 91.

164 HAKERİ, Genel Hükümler, s. 560; ÖZTÜRK / ERDEM, s. 373: “... fail, fiile bizzat katılmamış, ancak fiilin planlaması ve organizasyonunda belirleyici olmuş ise, fiilin işlenmesine katkl, zorunlu olarak tipiklikte yer alan unsurların da gerçekleştirilmesini gerektirmediğinden, bu kişi de müşterek fail saylmalıdır.".

165 ARTUK / GÖKCEN / ALŞAHIN / ÇAKIR, s. 660.

166 HAKERİ, Işstirak, S. 90.

167 Vasıta olarak kullanılan ve asıl fiili gerçekleştiren kişinin, hukuka uygun hareket ettiği veya kasten hareket etmediği hallerde, dolayısıyla faillik kurumu bulunmadığı takdirde, bu kişinin gerçekleştirmiş olduğu fiile iştirak edenlerin cezalandırılmasının mümkün olamayacağ 1 ifade edilmektedir. Bkz. HAKERİ, Iștirak, s. 93.

168 TOROSLU, s. 304

169 YÜCE, s. 85.
} 
ve kusursuz hareket eden kişinin hareket hâkimiyetine ileri derecede etkili olduğundan bu gibi hallerde azmettirmeden değil, dolayısıyla faillikten söz edileceği ifade edilmektedir ${ }^{170}$.

Dolayısıyla faillikte başka bir kimseyi araç olarak kullanan kişi kasten hareket etmelidir. Bu nedenle taksirli bir davranışla dolayısıyla faillik söz konusu olmaz ${ }^{171}$.

Bir suçun mağdurunun aynı zamanda faili olması mümkün olmamakla birlikte ${ }^{172}$ dolayısıyla faillikte suç işlemede kullanılan kişi bizzat mağdurun kendisi de olabilir ${ }^{173}$. Yine organize güçlerin başında bulunan kişilerin, organizasyonun alt kademesinde bulunan ve alet olarak kullanılan kişilerin işlediği suçlar yönünden dolaylslyla fail olduğunun kabulü gerektiği ifade edilmektedir ${ }^{174}$. Bu türden dolayısıyla failliğin, devlet gücünü istismar eden oluşumlar veya mafya benzeri örgüt yapılanmaları yönünden söz konusu olabileceği belirtilmektedir ${ }^{175}$.

Suç işlemede vasıta olarak kullanılan ve isnat yeteneği olmayan kişi akıl hastası olabileceği gibi ayırt etme gücüne sahip olmayan bir çocuk da olabilir. İsnat yeteneğinin esasında suç kavramına dâhil olmadığı ve cezai ehliyete ilişkin olduğu, kusurluluğun veya suçun değil, cezalandırabilmenin ön şartı olduğu ifade edilmektedir ${ }^{176}$. Bu durumda isnat yeteneği olmayan kişileri yönlendirilerek suç işletilmesi halinde dolayısıyla faillikten ziyade azmettirmeden söz edilebilir ${ }^{177}$. Ancak TCK'nın 37. maddesinin 2. fikrasının son cümlesinde "kusur yeteneği olmayanları suçun işlenmesinde araç olarak kullanan kişinin cezasının arttırılacă̆ı" öngörüldügünden, isnat yeteneğinin kusurun bir unsuru olarak kabul edildiğini söyleyebiliriz. Kanun'da yer verilen bu hüküm nedeniyle TCK 32. madde kapsamında isnat yeteneği bulunmayan bir kişiye ya da on iki yaşından küçük bir çocuğa uyuşturucu veya uyarıcı madde sattırılması, naklettirilmesi ya da başkasına temin için kullanılması hallerinde dolayısıyla faillik söz konusu olacak ve bu kişilere uyuşturucu madde sattıran kişi dolayısıyla fail olarak uyuşturucu madde ticaretinden sorumlu olacak ${ }^{178}$, ayrıca kusur yeteneği olmayanların suçta kullanılması nedeniyle TCK $37 / 2$ son cümle uyarınca temel cezadan artırım yapılacaktır ${ }^{179}$.

Bir kimseye cebir, şiddet, korkutma veya tehdit kullanarak suç işleten kişi de dolayısıyla fail ola rak kabul edilmektedir ${ }^{130}$. Cebir uygulayarak bir başkasını, uyuşturucu veya uyarıcı madde naklinde

170 HILGENDORF / VALERIUS, s. 211.

171 DEMIRBAŞ, s. 478.

172 BkZ. DÖNMEZER / ERMAN, s. 732.

173 Bkz. JESCHECK, Hans-Heinrich: Alman Ceza Hukukuna Giriş, (Çev.) YENISEY, Feridun, Beta Yayınevi, İstanbul, 2007, s. 45: “... dolaylslyla failliğin birinci hali, alet durumunda olan kişinin yaptı̆̆ hareketin suç teşkil etmemesi durumudur; mesela hiçbir şeyin farkinda olmayan suç kurbanının, yüksek gerilim nakleden tele dokunmasına yol açan kiși, niteliksiz kasten adam öldürme suçunu ișlemiş olur."

174 Dolayısıyla faillik biçimi olan "organizasyona egemenlik" görüşünü ilk ortaya atan yazarın Alman ceza hukukçusu Claus Roxin olduğu, bu tür dolayısıyla failliğin "masa başı faillik" olarak da adlandırıldığı ifade edilmektedir. Bkz. ÖZTÜRK / ERDEM, s. 376; TCK'nın 220/5. maddesinde, "örgüt yöneticileri, örgütün faaliyeti çerçevesinde işlenen bütün suçlardan dolayı ayrıca fail olarak cezalandırllı" hükmü yer almaktadır. Dolayısıyla Roxin'in bu teorisine dayanmadan da örgütün başındaki kişileri, üyelerin işlemiş olduğu suçlardan sorumlu tutmak mümkündür.

175 HILGENDORF / VALERIUS, s. 212. Bu teorinin geliştirilmesindeki itici gücün İkinci Dünya Savaşı öncesi Almanya'da, devlet içerisinde örgütlenen Nazilerin işledikleri suçlar ve bu oluşumun başındaki kişilerin sorumluluğunun tespiti olduğunu söylemek mümkündür. Ayrıca Alman Federal Yüksek Mahkemesinin, eski Doğu Almanya Demokratik Cumhuriyeti zamanında, sınır güveliği mensuplarının, kasıtlı bir şekilde, sınırı geçmeye çalışanları vurmaları dolayısıyla zamanın ulusal güvenlik kurulu mensuplarının dolayısıyla failliğini Roxin'in bu öğretisine dayanarak kabul ettiği nakledilmektedir. Bkz. ARSLAN, Mehmet: Alman Ceza Hukukunda Suç ve Terör Örgütleriyle Bağlantıll Suçlar ve İstirak Hükümleriyle İlişskileri, Adalet Yayınevi, Ankara, 2020, s. 94. Bu türden dolayısıla faillikte "hiyerarşik olarak teşkilatlanmış otoriter yapı içerisinde karar verme gücü", "doğrudan fiili işleyen kişinin değişebilirliği", "otoriter yapının hukukun dışında hareket etmesi" şartlarının birlikte gerçekleşmesi gerektiği ifade edilmektedir. Bkz. ÖZTÜRK / ERDEM, s. 382-383.

176 YALÇIN SANCAR, Türkan: Çok Failli Suçlar, Seçkin Yayınevi, Ankara, 1998, s. 211.

177 Farklı görüş için bkz. AYDIN, s. 168. Aydın, azmettirmenin varlığı için azmettirilmek istenen kişinin bunu idrak edebilmesi yani isnat yeteneği olarak tanımlanan anlama ve isteme yeteneğine sahip olması gerektiğini, çünkü isnat yeteneği olmayan kişilerin ya da kendi iradesi ile davranma olanağı bulunmayan kişilerin azmettirilmesinin olanaklı olmadığını ifade etmektedir.

178 TONGÜR, Ali Rıza / ÇETINTÜRK, Ekrem: Ceza Hukuku Genel Hükümler, Adalet Yayınevi, Ankara, 2020, s. 323.

179765 sayı1lı TCK'nın yürürlükte olduğu dönemde UUMiT suçunun düzenlendiği 403. maddenin 9. fikrasında “on sekiz yaşını bitirmeyen küçükleri veya ceza ehliyetine sahip bulunmayanları bu maddede yazll suçları işlemekte kullanan kimseler hakkinda, fiil için tertip olunacak ceza altıda bir oraninda arttrllarak hükmolunur." düzenlemesi yer almaktaydı.

180 ZAFER, s. 426; HAKERİ, İştirak, s. 96; GÜLŞEN, Recep: Ceza Hukukunda Sorumluluğu Kaldıran Nedenlerden Kaza, Mücbir Sebep, Cebir ve Tehdit, Seçkin Yayınevi, Ankara, 2007, s. 150, 170. 
kullanan kişi dolayısıyla fail olduğu için bu suçtan sorumlu olacak, cebir sonucu suç işleyen kişi ise TCK'nın 28. maddesi gereğince cezalandırılmayabilecektir ${ }^{181}$. Tehdit yoluyla bir kimseye uyuşturucu veya uyarıcı madde sattırılması durumunda da sattıran kişi dolayısıyla fail kabul edilerek uyuşturucu veya uyarıcı madde ticareti suçundan sorumlu tutulabilecekken, ağır ve muhakkak bir tehdit altında suç işleyen kişinin kusuru bulunmadığından cezalandırılması yoluna gidilemeyecektir ${ }^{182}$.

Yüksek Mahkemeye yansımış birkaç olayı irdelemek bu konuyu açıklamada faydalı olacaktır. Ka rakolda gözaltında bulunan kişiye yemek götürülmek istendiği, yemeğin içine uyuşturucu madde konulduğu, yemeği karakola götüren kişinin bundan haberi olmadığ 1 ve uyuşturucu maddenin karakol girişinde tespit edildiği olayda yemek içine uyuşturucu madde koyan kişi dolayısıyla fail olarak uyuşturucu ve uyarıcı madde ticaretinden sorumlu olacaktır. Yemeği götüren kişi aracı olduğundan ve uyuşturucu madde götürdüğünden haberi olmadığından kastı yoktur ve dolayısıyla kusuru bulunma maktadır. Bu nedenle yemeği götüren kişi bu suçtan sorumlu olmayacaktır ${ }^{183}$. Y ine yurt içinden, yurt dışına mal ihracının olduğu, ihraçta kullanılan sürücünün kendisine teslim edilen tırdaki uyuşturucu maddeden haberi olmadığ 1 olayda nakilde kullanılan tır sürücüsü, araç kişi olduğundan ve yine kastı bulunmadığından sorumlu değildir ${ }^{184}$.

Birinin uyuşturucu veya uyarıcı madde ticareti suçundan cezalandırılması için aracına ya da konutuna uyuşturucu madde konulması halinde failin hem uyuşturucu veya uyarıcı madde ticareti suçundan hem de iftira suçundan cezalandırılması gerektiği ifade edilmektedi ${ }^{185}$. Burada vasıta olarak kullanılan kişi iftira atılan kişinin kendisidir.

\section{Seriklik}

Kanun' da azmettirme (TCK m 38) ve yardım etme (TCK m. 39) olmak üzere iki farklı şeriklik türüne yer verilmiştir. Şerikliğe ilişkin düzenlemelerin sorumluluk alanını genişleten hükümler oldur $\breve{g u}^{186}$ göz önünde bulundurulduğunda bu şeriklik türleri dışında, şerik sıfatıyla suça iştirak etmenin mümkün olmadığı söylenebilir.

\section{Azmettiren}

Azmettirmede, hiç aklında yokken, bir kimseyi kanunda suç sayılan bir fiili işlemeye sevk etme hali söz konusudur ${ }^{187}$. Azmettirmeden söz edebilmek için azmettirilmeden önce azmettirilen kişide suç işleme düşüncesi bulunmamalıdır ${ }^{188}$. Bu konudaki ölçütün "azmettirme olmasaydı suç işlenmeyecekti" olması gerektiği ifade edilmektedir ${ }^{199}$.

Uyuşturucu maddenin nakli için bir kişinin azmettirilmesi, azmettirilen kişinin de nakil için bir başkasını azmettirmesinde olduğu gibi azmettirmeye azmettirme mümkündür ${ }^{190}$. Azmettirme; ikna, rica, ödül ya da menfaat vaadi gibi araçlar kullanılarak gerçekleştirilebilir ${ }^{191}$.

181 Kişinin karşı koyma, yardım çağırma veya kaçma imkânına sahip olduğu takdirde, cezasızlığı sağlayan TCK'nın 28. maddesinden faydalanamayacağı ifade edilmektedir. Bkz. GÜLŞEN, s. 144.

182 Kusurluğu kaldıran tehditten söz edebilmek için ise tehdidin muhakkak ve ağır olması, tehdit edilen kişinin tehditle istenen hususu gerçekleştirmekten başka türlü kaçınamaması, korunan ve ihlal edilen değerler arasında bir orantının bulunması gerekmektedir. Bkz. GÜLSEN, s. 161-164. TCK'nın 28. maddesinde belirtilen şartları taşımayan cebir ve tehdit hallerinde suc gerçeklestirilmișse, hem suc işletilen kişi yönünden cezasızlık söz konusu olmayacak hem de dolayısıyla faillikten değil azmettirme durumundan bahsedilecektir.

Benzer olay ve benzer yöndekarar için bkz. Yargitay, 10. CD., T. 13.03.2008, E. 2008/37, K. 2008/4310.

185 ÖNER, S. 195

186 ARTUK / GÖKCEN / ALŞAHIN / ÇAKIR, s. 664.

187 EREM / DANIŞMAN / ARTUK, s. 392: "Azmettirme kavrami, suçun ilk ve etkili nedenini yaratmak anlamina gelir".

188 ÖZTÜRK / ERDEM, s. 394.

189 ÖZBEK / DOĞAN / BACAKSIZ, s. 529.

190 HAKERİ, Genel Hükümler, s. 578; DEMİRBAŞ, s. 486: “... örneğin bir suç örgütü başının, adamlarından birisine, bir kiralık katil bulup aleyhine yazan gazeteciyi öldürtmesini istemesinde olduğu gibi...".

191 ÖZTÜRK / ERDEM, s. 394. 
TCK'nın 38/1. maddesine göre "başkasını suç işlemeye azmettiren kişi, işlenen suçun cezası ile cezalandirllacaktır". TCK'nın 38/2. maddesine göre de "üst soy ve altsoy ilişsisinden doğan nüfuz kullanılmak suretiyle suça azmettirme veya çocukların azmettirilmesi" hallerinde ceza arttırılmaktadır ${ }^{192}$.

Uygulamada genellikle uyuşturucu madde naklederken yakalanan kişiler; araçlarında bulunan uyuşturucu maddenin kendilerine ait olmadığı, tanımadıkları bir kişinin kendileri ile iletişime geçerek para karşılığı uyuşturucu madde taşıması teklifinde bulunduğu, bu teklifi kabul ettikleri şeklinde sa vunma yapmaktadırlar. Bu gibi hadiselerde uyuşturucu madde taşıtan kişi esasen azmettiren konur mundadır. Aynı zamanda uyuşturucu veya uyarıcı madde taşıtan bu kişiler, uyuşturucu veya uyarıcı maddenin sahibi olmaları ve hareket üzerinde ortak hâkimiyet kurmaları nedeniyle müşterek fail konumundadırlar. Failliğin şerikliğe asliliği kuralı gereğince bu kişiler, sadece fail olarak sorumlu ola caktır. Bazı durumlarda azmettiren, işlenen suçun cezasından daha ağır şekilde cezalandırılabildiği ${ }^{193}$ için bu tespit önemlidir.

Failin kullanmak için istediği uyuşturucu veya uyarıcı maddeyi bulunduğu yerden alıp getirmesi için bir başkasını azmettirmesi üzerine azmettirilen kişi, uyuşturucu veya uyarıcı maddeyi alıp azmettirene verdiği anda azmettirilen yönünden ticaret suçunun oluşacağı, kullanım amacı taşıyorsa azmettirenin de TCK 191. maddesi uyarınca kullanmak için uyuşturucu veya uyarıcı maddeyi satın alma, kabul etme veya bulundurma suçunu işlemiş olacağ 1 ifade edilmektedir ${ }^{194}$. Bizce bu görüş yerinde değildir. Zira azmettiren söz konusu uyuşturucu maddeyi kullanma niyetinde olsa da azmettirdiği hur sus aynı zamanda uyuşturucu veya uyarıcı maddenin bir yerden başka bir yere naklidir. Bu nedenle hem azmettiren hem de azmettirilen yönünden uyuşturucu veya uyarıcı madde ticareti suçunun oluşa cağının kabulü gerekir ${ }^{195}$.

Nitekim sanığın uyuşturucu maddeyi ceza infaz kurumuna sokmak isterken yakalandığı olayda, cezaevinde bulunan ve uyuşturucu maddenin getirildiği diğer sanığın azmettiren olduğu ve uyuşturucu madde ticareti yapma suçundan cezalandırılması gerektiği yönünde Yüksek Mahkeme kararı bulunmaktadir ${ }^{196}$.

Etkisiz (neticesiz) kalan azmettirme, TCK'da bu duruma ilişkin bir düzenleme yer almaması nedeniyle cezalandırılmamaktadır ${ }^{197}$. Mevcut suça iştirak düzenlemeleri dikkate alındığında etkisiz azmettirmenin cezalandırılması mümkün değildir. Zira suça iştirakten söz edebilmek için işlenecek olan suçun icra hareketine başlanmalıdır.

TCK'nın 38/3. maddesinde, azmettirmeye ilişkin olarak etkin pişmanlık hükmüne yer verilmiştir. TCK'nın 38/3. maddesine göre "azmettirenin belli olmaması halinde; kim olduğunu ortaya çıkmasını sağlayan fail veya diğer suç ortağı hakkında hükmedilen cezadan indirim yapılacaktır".

Kimi zaman uyuşturucu veya uyarıcı madde ticareti suçu failleri, etkin pişmanlık hükmünden faydalanmak için kendilerine uyuşturucu veya uyarıcı maddeyi veren ya da taşıtan kişi ya da kişilerin

192 Bu hükmün eleştirisi için bkz. AYDIN, s. 225: “Azmettireni işlenen suçtan sorumlu tutarak suçun kanundaki cezası ile cezalandırılmasını kabul eden bir sistemde sırf bu nedenle azmettirenin cezasının arttırılması isabetli değildir.".

TCK'nın 38/2. maddesine göre de "üstsoy ve altsoy ilişkisinden doğan nüfuz kullanılmak suretiyle suça azmettirme veya çocukların azmettirilmesi" hallerinde ceza üçte birden yarısına kadar arttırılmaktadır.

194 ELMAS, Birsen: Uyuşturucu ve Uyarıcı Madde Suçları, 4. Baskı, Adalet Yayınevi, Ankara, 2020, s. 200; İLTAŞ, s. 210; ayrıca bkz. SELBES, s. 139; Y OLCU, s. 137.

195 Benzer yönde görüș için bkz. KIDIL, Fahrettin: Türk Ceza Hukukunda Uyuşturucu veya Uyarıcı Madde Imal ve Ticareti Suçları, Adalet Yayınevi, Ankara, 2020, s. 297: “... sanığın kullanma kastıyla hareket etmesi, doğrudan kendisi tarafindan gerçekleştirilen uyuşturucu madde satın alma, kabul etme, bulundurma gibi haksız eylemler bakımından sonuç doğuracaktır. Esas haksızlı̆̆ın kaynă̆l ve seriklerin bağlı olduğu fiil azmettirilen tarafindan gerçekleştirilmektedir. Dolayısıla bu gibi durumlarda hem azmettirenin hem de failin cezai sorumluluğu, TCK'nın 188/3 'teki suç gereğince belirlenmelidir.".

196 Bkz. Yargitay, 20. CD., T. 07.07.2020, E. 2019/7270, K. 2020/3985.

197 Bkz. SOYASLAN, Genel Hükümler, s. 486: “İtalyan Ceza Kanunu'nun 115. maddesinde etkisiz kalan azmettirme hallerinde güvenlik tedbiri uygulanmaktadır.". Ayrıca bkz. DEMIRBAȘ, s. 483: "Alman Ceza Kanunu'nun 30. maddesinde neticesiz azmettirme cezalandlrılmaktadır.”. Alman Ceza Kanunu'ndaki bu hükmün, Duchense adlı bir Fransız'ın 40.000 Frank karşılığı Bismark'ı öldürmeye azmettirmesi ve bu olayın bir yıl sonra ortaya çıkması nedeniyle konulduğu ifade edilmektedir. Bkz. ÖNDER, s. 447. 
kimliklerini açıklamaktadırlar. Fail tarafından bu kişi ya da kişilerin adının verilmesi ve kimliğinin açığa çıkarılması durumunda TCK'nın 38/3. maddesinin mi, yoksa TCK'nın 192. maddesinde yer alan etkin pişmanlık hükmünün mü uygulanacağı sorunu ortaya çıkacaktır.

Azmettirilen kişi, azmettirenin kimliğini ortaya çıkmasını sağlar ise cezasından indirim yapılacaktır. Yine birden fazla azmettiren var ise azmettirilenin bu hükümden faydalanabilmesi için azmettirenlerin hepsinin kimliğinin ortaya çıkmasına katkı sağlaması gerektiği ifade edilmektedir ${ }^{198}$. Azmettirme düzenlemesinin yer aldığı 38. maddenin 3. fikrasındaki düzenleme genel nitelikte bir etkin pişmanlık hükmüdür ve şartları itibariyle uygulanması daha zordur. TCK'nın 192. maddesinde yer alan etkin pişmanlık hükmü ise UUMİT suçuna özgü olarak düzenlenmiştir. Özel hüküm olması nedeniyle TCK'nın 192. maddesi öncelikle uygulanacaktır ${ }^{199}$.

\section{Yardım Eden}

Suça yardım, iştirak edilen fiil üzerinde ortak hâkimiyet kurmayan, başka bir ifade ile müşterek faillik oluşturacak düzeye ulaşmayan ve azmettirme kapsamına girmeyen her türü maddi ve manevi katkıdır ${ }^{200}$. Yardım etme kasıtlı olmalıdır, ancak yardım edenin asıl failin kim olduğunu ve fiilin tüm ayrıntılarını bilmesi gerekmez ${ }^{201}$.

Şerik tarafından yardım etme fiili, asıl fail tarafından suç işlenmeden önce ya da işlendiği sırada yapılmalıdır. Suçun işlenmesinden sonra faile yardım edilmesi iştirak fiilini oluşturmaz ${ }^{202}$.

TCK'nın 39. maddesinin 1. fikrasında, suça yardım eden olarak iştirak edenin cezasından indirim yapılacağı belirtilmektedir. Aynı maddenin 2. fikrasında, hangi hareketlerin yardım etme kapsamında olduğu düzenlenmiştir. Kanunda yardım etme halleri sayma usulü ile belirtildiğinden bunlar dışında kalan hareketlerin, yardım etme kapsamında değerlendirilemeyeceği ifade edilmektedir ${ }^{203}$.

TCK'nın 39. maddesinin 2. fikrasına göre " a) Suç işlemeye teşvik etmek veya suç işleme kararını kuvvetlendirmek veya fiilin işlenmesinden sonra yardımda bulunacağını vaat etmek, b) Suçun nasıl işleneceği konusunda yol göstermek veya fiilin işlenmesinde kullanılan araçları sağlamak, c) Suçun işlenmesinden önce veya işlenmesi sırasında yardımda bulunarak icrasını kolaylaştırmak" şeklindeki hareketlerden herhangi birini yapan kişi işlenen suçtan dolayı yardım eden sıfatıyla sorumlu olur.

a) Manevi yardım türü olan suç işlemeye teşvikte suç işlemeyi düşünen, fakat henüz karar vermemiş olan faile suç işleme kararı aldırılmaktadır ${ }^{204}$. Suça teşvik hallerinde failin kafasında suç işleme fikri mevcuttur, ancak suç işleme konusunda henüz karar vermemiştir. Bu yönüyle azmettirmeden farkl111k göstermektedir ${ }^{205}$. UUMİT suçunu işlemeyi düşünen bir kişinin bu düşüncesini onaylayıc1 veya destekleyici hareketlerde bulunmak teşvik etme kapsamında değerlendirilebilecektir ${ }^{206}$. Diğer manevi yardım türü olan suç işleme kararını kuvvetlendirmede, bir suç işlemeye karar vermiş failin, karar aşamasından icra aşamasına geçmesini sağlamaya yönelik hareketler gerçekleştirilmektedir $r^{207}$. Suç işleme kararını kuvvetlendirmede, geçmişe doğru bir değerlendirme yapılarak yardım edenin telkin ve benzeri hareketlerinin, karar aşamasından hareket aşamasına geçilmesinde etkili

\footnotetext{
198 HAFIZOĞULLARI / ÖZEN, Genel Hükümler, s. 341.

199

TCK'nın 192. maddesinin 1 ve 3. fikralarında UUMIT suçlarına iştirak etmiş olan kişinin, suç haber alınmadan önce etkin pişmanlık göstermesi halinde ceza almayabileceği, suç haber alındıktan sonra suçun meydana çıkması ve fail ya da diğer suç ortaklarının yakalanmasını sağlaması halinde ise cezasından indirim yapılabileceği hüküm altına alınmıştır.

200 TONGÜR / ÇETINTÜRK, s. 331; HAKERİ, Genel Hükümler, s. 532; EVIK, s. 189.

201 DEMIRBAŞ, s. 488.

202 TOROSLU, s. 312.

203 EREM / DANIŞMAN / ARTUK, s. 401.

204 ZAFER, S. 428.

205 ÇELEN, Ömer: Bir İstirak Sekli Olarak Yardım Etme (Asli Fail-Yardım Eden Ayrımı), Adalet Yayınevi, Ankara, 2020, s. 293.

206 Bkz. EVIK, s. 225.

207 TOROSLU, s. 327.
} 
olup olmadığının tespiti yapılmaktadır ${ }^{208}$. Ayrıca belirtmeliyiz ki, yardım eden kişinin, failin fiiline kasıtlı olarak katkı sağlaması gerekmektedir. Bir kişiye konuşma arasında sadece uyuşturucu veya uyarıcı madde imal ve ticaretinde çok para olduğunun söylenmesi ve bu konuşmadan etkilenen failin de bu suçu işlemesi hali bizce yardım etme şeklindeki iştirak türü kapsamında değerlendirilemez. Zira taksir ile bir suça iştirak etmek mümkün değildir.

Suçun işlendiği yerde hiçbir şey yapmadan, gönüllü olarak bulunmanın dahi faili teşvik etme veya suç işleme kararını kuvvetlendirme suretiyle manevi yardım kapsamında değerlendirilebileceği ifade edilmektedi $r^{209}$. Şüphesiz bu gibi bir durumda da kişide açık ya da zımni suça iştirak iradesinin bulunmasi gerekir ${ }^{210}$.

Fiilin işlenmesinden sonra yardımda bulunacağının vaadi suç tamamlanmadan önce yapılmalıdır. Öncesinde veya işlenmesi sırasında böyle bir vaat yoksa yardım etme kapsamında değerlendirilemeyecek, suç işlendikten sonra faile yardımda bulunmak başka bağımsız bir suçu oluşturacak$\mathrm{t}^{2}{ }^{211}$. Bu iştirak halinde, vaat edilenin suç işlendikten sonra yerine getirilip getirilmemesi önem taşımaz ${ }^{212}$. Uyuşturucu veya uyarıcı maddeyi aracı ile nakleden kişiye, yakalanması durumunda ailesine yardım edileceği ve cezaevinde bakılacağı vaadinde bulunan kişinin yardım eden olarak sur ça iştirak ettiğinin kabulü gerekir ve sonradan bu sözlerin yerine getirilmemesi cezai sorumlulur ğunu etkilemez.

b) Suçun nasıl işleneceği konusunda yol göstermekte; yol gösteren kimse faili yönlendirmekte, faile tavsiyelerde bulunmakta ve akıl vermek suretiyle failin iradesine etkide bulunmaktadır ${ }^{213}$. Ancak bu türden yol gösterici hareketlerin suç işlenmeden önce yapılması gerekmektedir. Zira suç işlenirken yapılan yol gösterme müşterek faillik kapsamına girebilecektir ${ }^{214}$.

"Fiilin işlenmesinde kullanılan araçları sağlamak" yardım türleri arasında sayılmıştır. TCK'nın 39/2. maddesinde "fiilin işlenmesinde kullanılan araçları sağlamak" şeklinde bir ifadenin yer alması nedeniyle bu fikranın uygulanabilmesi için aracın suçta kullanılmaya elverişli olması ve muhakkak suçta kullanılmış olması gerekmektedir ${ }^{215}$. Bununla birlikte aracın suçta kullanılmaması ya da elverişli olmaması durumunda gerçekleştirilen hareket, manevi şekilde yardım etme türlerinden birisine girebilir $r^{216}$. Aracın fiilin icrası sırasında sağlanması halinde, somut olayın koşullarına göre müşterek failliğin söz konusu olabileceği ifade edilmektedir ${ }^{217}$.

Bir gayrimenkulün suçta kullanılması için başkasına tahsis edilmesinin, araç tahsisi şeklindeki yardım etme kapsamına girebileceği ifade edilmiş ise de ${ }^{218}$; UUMIT suçu yönünden durum farkl1dır. Zira suç tanımında depolama, bulundurma gibi hareketlerin müstakil suç olarak kabul edilmesi nedeniyle, taşınmazını kullandıran ya da tahsis eden gayrimenkulün sahibi müşterek fail olarak sorumlu tutulabilecektir ${ }^{219}$.

\footnotetext{
208 BkZ. DÖNMEZER / ERMAN, s. 838.

209 HAKERİ, Genel Hükümler, s. 584.

210 İÇEL, s. 535.

211 ÇELEN, s. 302: “... örneğin, hırsızlık suçu işlendikten sonra elde edilen altınların elden çıkarılmasına sağlanan katkı TCK md. 165'te yer alan suça iştirakten dolayl sorumluluk gerektirir.".

212 TANER, s. 543.

213 DÖNMEZER / ERMAN, s. 839.

214 ÖNDER, S. 469.

215 EVIK, s. 217.

ÖNDER, s. 468; DEMIRBAŞ, s. 489

ZAFER, s. 429.

218 TANER, S. 545: “... bir kimsenin evini veya evinin bir odasını suç faillerine tahsis etmesi vasita tedariki kabilindendir.”. Ayrıca bkz. ÖZBEK / DOĞAN / BACAKSIZ, s. 536.

219 Bkz. Yargitay, 10. CD., T. 26.02.2016, E. 2016/82, K. 2016/547.
} 
c) Suçun işlenmesinden önce veya işlenmesi sırasında yardımda bulunma halinde, suç işlenirken zorunlu olmayan hareketlerde bulunularak failin hareketleri kolaylaştırılmaktadır ${ }^{220}$. Fiil ve faile araç sağlamak dışındaki tüm kişisel hizmetlerin suçun icrasını kolaylaştırmak kapsamında değerlendirilebileceği ifade edilmektedir ${ }^{221}$. Kanun koyucunun suçun icrasını kolaylaştıran her türlü katkıyı, desteği cezasız bırakmamak amacıyla bu şekilde torba bir hüküm getirdiği belirtilmektedir ${ }^{222}$. UUMiT suçunun işlenmesi yönünden araç sağlama dışındaki her türlü maddi katkı, müşterek faillik kapsamı dışında olmak şartıyla bu bent kapsamında değerlendirilebilecektir.

Yüksek Mahkeme kararlarında uyuşturucu veya uyarıcı maddenin taşınmasında kullanılan aracı temin etme ${ }^{223}$, kiralama ${ }^{224}$; satılan uyuşturucu veya uyarıcı madde ile doğrudan ilgisi bulunmamak şartıyla uyuşturucu veya uyarıcı madde satışına aracı olma ${ }^{225}$; alışveriş sırasında yanında bulunmamak şartıyla uyuşturucu veya uyarıcı maddenin alıcı ile satıcısının buluşmasını sağlama ${ }^{226}$, tel efon görüşmeleri yaparak ya da başka bir şekilde uyuşturucu veya uyarıcı madde alıcılarını satıcıya yönlendir$\mathrm{me}^{227}$; uyuşturucu veya uyarıcı madde satın alınacağını bilerek faillere para gönderme ${ }^{228}$; uyuşturucu veya uyarıcı madde satan kişinin parasını alamaması üzerine paranın tahsili için satıcıya yardımda bulunma ${ }^{229}$; uyuşturucu veya uyarıcı madde satın alınması için gerekli olan paraların havalesinin yapılabilmesi maksadıyla banka hesabı açıp diğer suç ortaklarının kullanımına bırakma ${ }^{230}$; uyuşturucu veya uyarıcı madde satın alınması için gerekli olan paraların kendi adına gönderilmesine izin verme ve gelen paraları suç ortaklarına iletme ${ }^{231}$; uyuşturucu veya uyarıcı maddenin nakli için araç satın alma ve ele geçirilmesini önlemek amacıyla araca gizli bölme yapma ${ }^{232}$; uyuşturucu veya uyarıcı madde imal ve ticaret suçunu işleyen failler arasında iletişimi sağlama ya da faillere suçun işlenmesi sırasında bilgi vererek suçun icrasını kolaylaştırma ${ }^{233}$; uyuşturucu veya uyarıcı maddenin kalitesini kontrol etme ${ }^{234}$; uyuşturucu veya uyarıcı maddenin taşınmasında kolaylık sağlamak amacıyla adına şirket kurulmasına ve şirket adına araç kayıt edilmesine izin verme ${ }^{235}$; uyuşturucu veya uyarıcı madde satıcısı olan faile yeni uyuşturucu maddeler geldiğini uyuşturucu veya uyarıcı madde kullanıcılarına haber verme ${ }^{236}$ veya uyuşturucu alışverişinde cep telefonunu kullandırma ${ }^{237}$; uyuşturucu veya uyarıcı madde sahiplerini,

220 AYDIN, S. 183.

221 EVIK, s. 220.

222 EVIK, s. 220.

223 Yargıtay, 20. CD., T. 24.10.2016, E. 2016/1340, K. 2016/21433: “... sanı̆̆ın diğer sanığa uyușturucuları naklettiği aracı vermekten ibaret eylemi...”. Ayrica bkz. Yargitay, 10. CD., T. 20.10.2016, E. 2016/5244, K. 3107, (kararı aktaran ELMAS, s. 195).

224 Bkz. Yargıtay, 20. CD., T. 19.12.2018, E. 2018/3392, K. 2018/6130: “... sanı̆ğn kiraladı̆̆ı aracı diğer sanıklara vermek suretiyle TCK'nın 39/2-b maddesi kapsamında diğer sanıkların suçuna yardım eden sıfatıyla katıldı̆̆ı...”. Ayrıca bkz. Yargıtay, 10. CD., T. 24.01.2019, E. 2018/5386, K. 2019/512, (karar1 aktaran ELMAS, s. 195).

225 Bkz. Yargıtay, 10. CD., T. 04.11.2020, E. 2020/14080, K. 2020/4087: “... sanığın diğer sanık ile irtibatını kurarak suç konusu uyuşturucu maddeyi satın almasını sağlama şeklinde gerçekleşen fiilinin TCK'nın 39. maddesi uyarınca sanığa yardım eden slfatında iş̧tirak niteliğinde olduğu...”. Ayrıca bkz. Yargitay, 10. CD., T. 12.07.2011, E. 2011/8782, K. 2011/20016, (kararı aktaran ELMAS, s. 195).

226 Bkz. Yargitay, 10. CD., T. 22.11.2018, E. 2018/2485, K. 2018/8304: “... diğer sanığın kendisinden uyuşturucu madde temin etmek hususunda yardım istediği ve sanığın bu amaçla diğer sanı̆̆ı uyuş̧turucu madde satıcllarının bulunduğu yere götürdüğ̈̈...” Ayrıca bkz. Yargitay, 20. CD., T. 09.07.2019, E. 2018/3697, K. 2019/4214.

227 Bkz. Yargitay, 10. CD., T. 18.11.2020, E. 2020/15402, K. 2020/7762; Yargitay, 20. CD., T. 26.10.2015, E. 2015/14607, K. 2015/4352: “... sanıkların alıcı konumundaki kişileri, uyuşturucu madde satıcılarına yönlendirerek uyuşturucu madde temininde aracıllk ettikleri, dolayısıyla suçun işlenmesinde yardım eden konumunda oldukları...”. Ayrıca bkz. Yargıtay 10. CD, T. 23.06.2011, E. 2010/38949, K. 2011/5142, (kararı aktaran ELMAS, s. 196).

228 Bkz. Yargitay, 9. CD., T. 23.11.2015, E. 2015/17194, K. 2015/7161.

229 Bkz. Yargitay, 20. CD., T. 15.10.2015, E. 2015/8238, K. 2015/3958; Yargitay, 10. CD., T. 27.11.2018, E. 2018/4364, K. $2018 / 8403$.

230 ELMAS, s. 196.

231 Bkz. Yargitay, 10. CD., T. 19.03.2018, E. 2017/6784, K. 2018/2710, (kararı aktaran ELMAS, s. 196).

232 Yargitay 10. CD., T. 02.03.2017, E. 2016/3449, K. 2017/798; ayrica bkz. Yargitay, 10. CD., T. 27.06.2011, E. 2009/21446, K. 2011/5236, (kararı aktaran ELMAS, s. 197).

233 Yargitay, 10. CD., T. 17.09.2015, E. 2014/14483, K. 2015/32259; ayrica bkz. ELMAS, s. 197.

234 Bkz. Yargitay, 10. CD., T. 07.04.2011, E. 2010/56279, K. 2011/3840, (kararı aktaran ELMAS, s. 197).

235 Bkz. Yargitay, 10. CD., T. 01.03.2012, E. 2011/12876, K. 2012/2386, (kararı aktaran ELMAS, s. 197).

236 Bkz. Yargitay, 10. CD., T. 07.11.2016, E. 2016/1974, K. 2016/3525, (kararı aktaran ELMAS, s. 197-198).

237 Bkz. Yargıtay, 20. CD., T. 30.10.2017, E. 2015/9477 K. 2017/5622: “... uyuşturucunun kullanıcılara ulaştırılması konusunda kendisine ait cep telefonunu kullandırmasından ibaret eyleminin TCK'nın 39. maddesi kapsamında suçun işlenmesi sırasında yardım etmek olarak değerlendirilmesi gerektiği gözetilmeden...". 
uyuşturucu veya uyarıcı maddenin bulunduğu aracın yanına götürme $e^{238}$; uyuşturucu veya uyarıcı maddenin nakli için uyuşturucu maddenin sahibi ile nakledecek kişiyi tanıştırma ${ }^{239}$ ya da nakledecek kuryeyi ${ }^{240}$ veya şoförü temin etme ${ }^{241}$; uyuşturucu veya uyarıcı madde paketlenmesinde kullanılmak üzere kesilen kâğıtları katlama veya uyuşturucu veya uyarıcı maddenin paketlenmesinde kullanılan malzemeleri bulundurma ${ }^{242}$; uyuşturucu veya uyarıcı madde teminini kolaylaştırmak amaciyla polislerin olay mahallinde bulunduğunu şifreli ya da mesaj yoluyla haber verme ${ }^{243}$; gözcülük yapma ${ }^{244}$ gibi hareketler yardım etme kapsamında değerlendirilmiştir.

Yüksek Mahkemenin vermiş olduğu kararlar dikkate alındığında, faillik ile yardım eden ayrımı yapılırken öncelikle failin hareketinin, kanuni tipte yer alan seçimlik hareketlerden birinin kapsamına girip girmediğine bakıldığını söylemek mümkündür ${ }^{245}$.

Uyuşturucu veya uyarıcı maddeyle herhangi bir şekilde temas halinde ya da hukuki terimle ifade etmek gerekirse bulundurma sayılabilecek ölçüde temas kurulması durumunda, temas eden ya da bur lunduran kişinin fail olarak sorumlu tutulduğunu söylemek mümkündür ${ }^{246}$. Nitekim cezaevi bahçesine atılan esrarı diğer sanığa iletmek için alarak bulunduran sanığın yardım eden olarak değil, fail olarak sorumlu tutulması gerektiğine hükmedilmiştir ${ }^{247}$.

TCK'nın 37. maddesinin gerekçesinde “failin, müşsterek fail mi yoksa yardım eden mi olduğunun tespiti yapılırken gerçekleştirilen suçun bütünlüğ̈̈ne bakılmasının gerektiği, bir işyerinde işlenen yağma suçunda, dlşarıda gözcülük yapan kişinin fiilinin diğer kişilerle birlikte işlenen yağma suçunun gerçekleşmesine olan etkisi bir bütün olarak değerlendirildiğinde, gözcü̈lük yapan kişinin de diğer suç ortaklarlyla birlikte suçun işlenişi üzerinde ortak hâkimiyet kurduğu sonucuna ulaşılacağl, bu durumda gözcülük yapan kişinin de fail olarak sorumlu tutulması gerektiği" ifade edilmiştir ${ }^{248}$. Somut olayın bütünlüğüne bakıldığında UUMiT suçunun işlenmesinde gözcülük yapan kişi müşterek fail olarak kabul edilebilecektir. Ancak Yüksek Mahkeme, yukarıda belirttiğimiz üzere uyuşturucu madde ile doğrudan ilgisi bulunmamak şartıyla uyuşturucu madde satışı yapılırken gözcülük yapan kişilerin yardım eden sıfatıyla sorumlu olması gerektiğine hükmetmektedir. Uyuşturucu veya uyarıcı madde nakli sırasında, suça konu maddelerin yakalanmaması için öncül araç ile nakil güzergâhındaki yol kontrolle rini tespit ederek nakledenlere bildiren kişilerin Yüksek Mahkemece müşterek fail olarak sorumlu tutulduğunu daha önce açıkladık. Her iki durumda gerçekleştirilen hareketlerin ve etkilerinin birbirinden farklı olması nedeniyle farklı sonuçlara ulaşıldığını söylemek gerekir. Uyuşturucu veya uyarıcı maddenin nakli için öncül araç kullanmak suçun tamamlanması için zorunluluk olarak kabul edilirken, uyuşturucu veya uyarıcı madde satışı ya da temini gerçekleştirilirken kullanılan gözcünün fonksiyonu suçun başarıyla icrası için tali nitelikte kabul edilmektedir ${ }^{249}$.

\footnotetext{
238 Bkz. Yargitay, 10. CD., T. 12.07.2018, E. 2018/1316, K. 2018/5713: “... suç konusu uyuşturucu madde ile doğrudan ilgisi kanttlanamayan sanığın uyuşturucu madde sahipleri diğer sanıkları uyuşturucu maddenin bulunduğu aracın yanına götürüp...” (kararı aktaran ELMAS, s. 198).

239 Bkz. Yargitay, 20. CD., T. 21.02.2019, E. 2018/4812, K. 2019/1088.

240 Bkz. Yargitay, 20. CD., T. 03.04.2019, E. 2018/1174, K. 2019/2072.

241 Bkz. Yargitay, 10. CD., T. 13.05.2010, E. 2010/304, K. 2010/11590, (kararı aktaran ELMAS, s. 197).

242 Bkz. Yargitay, 20. CD., T. 18.06.2018, E. 2015/9819, K. 2018/2766, (kararı aktaran ELMAS, s. 198).

243 Bkz. Yargitay, 20. CD., T. 06.11.2017, E. 2017/5248, K. 2017/5794. Ayrica bkz. Yargitay, 10. CD., T. 16.09.2019, E. 2019/1407, K. 2019/5552: “... olay yerinin yakinında polisleri görünce bu sanıklara yönelik onlart ikaz etmek için 'ayık ol' diye bağırmast şeklinde gerçekleşen eyleminden dolayı TCK'nın 39. maddesi kapsamında yardım eden sıfatı ile sorumlu olduğu...".

244 Bkz. Yargitay, 20. CD., T. 22.01.2020, E. 2019/1125, K. 2020/766: “... sanığın gözcülük yaptı̆̆ ve eyleminin TCK'nın 39/1. maddesi kapsamında kaldı̆̆ı, sanığın yardımda bulunarak suçun icrasını kolaylaştırdığı...”. Ayrıca bkz. Yargıtay, 20. CD., T. 16.01.2018, E. 2015/9374, K. 2018/288, (kararı aktaran ELMAS, s. 198).

245

Bkz. Yargitay, 10. CD., T. 17.09.2015, E. 2014/14483, K. 2015/32259: “... somut olayda santklartn TCK'nin 188. maddesinin 3. fikrasinda seçimlik olarak sayllan hareketlerden herhangi birini gerçeklesstirdiklerine; bu bağlamda suc konusu uyusturucu maddenin temini, yüklenmesi, paketlenmesi, taşınması gibi bir fiile katıldıklarına ya da uyuşturucu maddeye ortak olduklarına ilişskin hiçbir delil bulunmadiğı...".

246 Bkz. ELMAS, s. 198; KIDIL, s. 298.

247 Bkz. Yargitay, 10. CD., T. 18.11.2020, E. 2017/5574, K. 2020/7845.

248 Bkz. TCK 37 Madde Gerekçesi.

249 EVIK, s. 254-255.
} 
Elde edilen paradan yararlanmanın tek başına suça yardım olarak değerlendirilemeyeceği ifade edilmektedir ${ }^{250}$. Bu nedenle UUMIT suçunun işlenmesine iştirak etmemek ile birlikte işlenen suç dola yısıyla elde edilen gelirden faydalanmış olmak tek başına yardım etme kapsamında değerlendirilemez.

765 sayılı TCK'nın yürürlükte olduğu dönemde, UUMiT suçunun düzenlendiği 403. maddenin 5. fikrasında "uyuşturucu maddenin alınıp satılmasına veya devrine veya ne suretle olursa olsun tedarik edilmesine aracı olanların" cezalandırılacağı hüküm altına alınmıştı. Bu hüküm nedeniyle uyuşturucu maddelerin alınıp satılmasına veya devrine ya da her ne suretle olursa olsun tedarikine vasita olanların da asli fail gibi cezalandırılması gerektiği ifade edilmekteydii ${ }^{251}$. 5237 sayılı TCK'nın 188/3 hükmündeki suç tanımının, önceki düzenlemeden farklı olması nedeniyle satılan uyuşturucu veya uyarıcı madde ile doğrudan ilgisi bulunmamak şartıyla uyuşturucu veya uyarıcı madde satışına aracı olma yardım etme kapsamında değerlendirilmektedir.

UUMITT suçu için öngörülen ceza süreli hapis cezası olduğundan, herhalde uyuşturucu veya uya rıcı madde imal ve ticaret suçuna yardım eden olarak iştirak eden kişinin cezası TCK 39/1' in son cümlesi uyarınca sekiz yılı geçemeyecektir ${ }^{252}$.

\section{Uyuşturucu veya Uyarıcı Madde İmal ve Ticareti Suçu Yönünden Kışkırtıcı Ajan, Gizli Soruşturmacı ve Kontrollü Teslimat}

Bir kişiyi suçüstü yakalamak veya o kişinin cezalandırılmasını sağlamak maksadıyla ilgili kişiyi bir suç işlemeye yönelten, suç işlemesine yardım eden veya suç işlemesi bakımından fırsat yaratan kişiye kışkırtıcı ajan denilmektedir ${ }^{253}$. Kolluk görevlisi kişinin alıcı kılığına girerek uyuşturucu veya uyarıcı madde ticareti suçunu ortaya çıkarmak için satın alma faaliyeti yürütmesine kurmaca alıcı (fictus emptor) yöntemi denmektedir ve bu yöntem de kışkırtıcı ajan faaliyeti içerisinde değerlendirilmektedir ${ }^{254}$.

Suç ve suçlunun ortaya çıkarılması için kışkırtıcı ajan faaliyetinin yürütüldüğü durumda, satıcının ve kurmaca alıcının cezai sorumluluğunun ne olacağının tespit edilmesi gerekmektedir.

Satıcı yönünden değerlendirme yapmak gerekirse kışkırtılanın yani satıcının, kışkırtma konusu suçun icrasına başlamış, fakat kışkırtıcı tarafından önceden çağrılan kolluk kuvvetlerinin engellemesi ile suçu tamamlayamamışsa teşebbüsten dolayı sorumlu olması gerektiği, uyuşturucu madde alımsatımı bağlamında düşünüldüğünde, sözleşme ilişkisinin tarafı olan ve kışkırtıcı ajan tarafından tahrik edilen kışkırtılanın, uyuşturucu madde ticareti suçuna teşebbüsten sorumlu olması gerektiği ifade edilmektedir ${ }^{25}$. Ancak kışkırtıcı ajanın kullanıldığı bu gibi hallerde UUMİT suçu yönünden kışkırtılanın suça teşebbüsten dolayı cezalandırılması, kanuni tip dikkate alındığında, pek olası görünmemektedir. Zira sadece ticari maksatla bulundurma ya da satışa arz etme gibi hareketlerin yapılması bile tamamlanmış suçtan cezalandırılma için yeterlidir. Bununla birlikte kışkırtıcı ajanın bir eczacıyı reçetesiz satılamayan, uyuşturucu ve uyarıcı madde niteliğinde olan ilacı satmaya ikna ettiği $i^{256}$ hallerde suça teşebbüs söz konusu olabilecektir.

Yüksek Mahkeme gerekli şartları haiz gizli soruşturmacı tarafından uyuşturucu satıcısından uyuştur rucu madde satın alınması durumlarında uyuşturucu madde ticareti suçunun oluşacağına hükmetmektedir.

\footnotetext{
250 HAKERİ, Genel Hükümler, s. 581.

251 ERMAN / ÖZEK, s. 281; GÜNAL, s. 99.

252 Bkz. Yargitay, 10. CD., T. 11.07.2017, E. 2017/597, K. 2017/3461.

253 TAŞKIN, Ozan Ercan: Kışskrtıcı Ajan, Seçkin Yayınevi, Ankara, 2011, s. 23.

254 Bkz. TAŞKIN, s. 107-115.

255 TOROSLU, s. 319. Aynı doğrultuda görüş için bkz. CENTEL, Nur / ZAFER, Hamide / ÇAKMUT, Özlem: Türk Ceza Hukukuna Giriş, 7. Bası, Beta Yayınevi, İstanbul, 2011, s. 499: “... gizli soruşturmacı kullanılan suçlarda failin sorumluluğunun tamamlanmış suçtan değil, suça teşebbüsten olması gerekmektedir çünkü ortaya çıkan netice, suç tanımındaki netice değil, gerçek olmayan kurgusal neticedir.".

256 EREM / DANISSMAN / ARTUK, s. 393.
} 
Ancak Yüksek Mahkemenin failin cezalandırılması yönündeki gerekçesi, fail tarafından gizli soruşturma crya uyuşturucu madde satılması ya da temin edilmesi şeklindeki harekete değil, failin satmak için uyuştur rucu madde bulundurması ya da satışa arz etmesi şeklindeki hareketine dayandırılmaktadır ${ }^{257}$. Gizli soruşturmacının kurmaca alıcı rolüne bürünerek uyuşturucu veya uyarıcı madde satın alma fiilinin satıcı yönünden başlı başına suç oluşturmadığı, bu fiilin sadece satmak için uyuşturucu madde bulundurma ya da uyuşturucu maddeyi satışa arz etme şeklindeki harekete ilişkin delil toplanması faaliyeti olduğu değerlendirilmesi yapılmaktadır ${ }^{258}$. Nitekim gizli soruşturmacının, farklı zamanlarda failden birden fazla uyuşturucu veya uyarıcı madde satın alma eylemlerinin, esasen satış için bulundurma ya da satışa arz etme şeklindeki hareket ile gerçekleştirilen tek bir suçun delili niteliğinde olduğu; birden fazla satın alma eylemi olsa da esasen tek suçun oluştuğu, ortada tek suçun var olması nedeniyle zincirleme suç hükmünün uygulanmayacağı hususu istikrarlı olarak Yüksek Mahkeme kararlarında belirtilmektedir ${ }^{259}$.

UUMITT suçunun ortaya çıkarılması için kışkırtıcı ajan kullanıldığında, kışkırtıcı ajanın cezai sorumluluğunun olup olmadığını belirlemek gerekmektedir. Zira icra hareketi başlamadan, kışkırtılan kişi, tamamen kışkırtıcının hareketi sonucunda suça yönelmiş ise kışkırtıcı ajan azmettiren, buna karşılık kışkırtılanda suçu işleme düşüncesi var idiyse teşvik eden konumundadır ${ }^{260}$. Başka bir ifade ile bu gibi alım satımlarda kışkırtıcı ajanın suça iştirak hükümleri uyarınca cezalandırılması gündeme gelebilecektir. Sadece kamu görevlisinin değil, üçüncü bir kişinin de alıcı olarak belirlenip kamu görevlileri tarafından suçüstü yapıldığı hallerde, kurmaca alıcı rolündeki üçüncü kişinin uyuşturucu ve uyarıcı madde ticareti suçuna azmettiren ya da teşvik eden şeklinde sorumluluğu doğabilecektir ${ }^{261}$.

Şüphesiz kolluk güçleri, suç ve suçluyla mücadele etmek için vatandaşlardan yardım isteyebilecek ve vatandaşların bilgisine başvurabilecektir. Ancak devlet adına hareket eden kolluk gücünün herhangi resmi sıfat taşımayan bir kişiyi kurmaca alıcı görevi vererek başka bir vatandaşı tuzağa düşürme şeklindeki hareketi herhalde hukuka aykırı olacaktır. Bu yüzden uyuşturucu veya uyarıcı madde imal ve ticareti suçunu ortaya çıkarması için kurmaca alıcı rolündeki kışkırtıcı ajan olarak kullanılan kişinin muhakkak yetkili makamlarca görevlendirilmiş kamu görevlileri olması gerektiğini düşünmekteyiz. Kamu görevlisi olmayan üçüncü bir kişinin kullanılması halinde elde edilen delil hukuka aykırı kabul edilmeli, bu üçüncü kişinin tanıklığı da hükme esas alınmamalıdır.

Kışkırtıcı ajanın söz konusu suça iştirakten sorumlu olmaması gerektiği öğretide, gönüllü vazgeçme ${ }^{262}$, işlenemez suç ${ }^{263}$, kastın yokluğu ${ }^{264}$, kanun hükmünü yerine getirme ve amirin emrini ifa ${ }^{265}$

257 Bkz. Yargitay, CGK., T. 30.01.2020, E. 2017/20-1077, K. 2020/43: “Adli kolluk görevlilerince sanıktan yapılan alımların hepsi ayrı ayrı suç oluşturmaya devam eden 'satmak için uyuşturucu madde bulundurma veya uyuşturucu maddeyi satışa arz etme' eyleminin tespiti niteliğindedir.".

258 Bkz. Yargitay, 10. CD., T. 09.02.2021, E. 2017/5994, K. 2021/1871: “... görevlilerin değişik tarihlerdeki satın alma işlemlerinin suç delillerini elde etmeye yönelik çalı̧̧malar kapsamında değerlendirilmesi gerektiği...".

259 Bkz. Yargıtay, CGK., T. 04.10.2016, E. 2016/9-994, K. 2016/340: “... kolluk görevlilerinin dört farklı tarihte yaptığı uyusturucu madde alımlarından dolayı, yapılan ilk alımla sanı̆̆ı 'satmak için uyuşturucu veya uyarıcı madde bulundurma' suçuna ilişskin olarak delillendirme işlemi yapıldığından, daha sonraki alımların TCK'nın 43. maddesi kapsamında ayrı suç oluşturmadığı ve sanık hakkında zincirleme suç hükümlerinin uygulanma şartlarının bulunmadı̆̆ının gözetilmemesi...".

260 İÇEL, s. 550; CENTEL / ZAFER / ÇAKMUT, s. 498.

261 EREM / DANIŞMAN / ARTUK, s. 393.

262 BkZ. TOROSLU, S. 318: “... buna göre tahrikin konusunu oluşturan suçun icra hareketlerinden gönüllü olarak vazgeçen veya kendi çabalarlyla suçun tamamlanmasını ve sonucun gerçekleşmesini önleyen tahrikçi ajan gönüllü vazgeçme hükümlerinden faydalanacak, yani söz konusu suça teşebbüsten dolayı cezalandırılmayacaktır. (TCK m. 36, 41/1). Aynı şekilde tahrikin konusu olan suçun, gönüllü vazgeçen tahrikçi ajanın gösterdiği önleme gayreti dışında başka bir sebeple işlenmemiş olması veya gönüllü vazgeçen tahrikçi ajanın bütün gayretine rağmen işlenmiş olması durumunda da gönüllü vazgeçmeye iliş̧kin hükümler uygulanacak ve tahrikçi ajana ceza verilmeyecektir (TCK m. 41, f. 2).".

263 Bu konudaki tartışmalar için bkz. ALACAKAPTAN, s. 99-11. Alacakaptan'a göre, kışkırtıcı ajanın müdahale ettiği olayların hepsinde, hareketin elverişsizliği sebebiyle bir işlenemez suçun mevcut olduğunu ileri süren görüş kabul edilemez. Bkz. ALACAKAPTAN, s. 106.

264 TAŞKIN, s. 114: "Bu mesele, suçun manevi unsuru bağlamında yapılacak bir değerlendirme ile çözülmelidir. Kışkırtıcı ajanın, alıma ilişskin zihni kaydl, yani aslında malı satın almak değil de suçu ortaya çıkarma iradesi, onda malın gerçek sahibi olma isteğinin olmadığının göstergesidir. Kış̧krttıcı ajan sözleşmeyi tamamlamak noktasında iradesini ortaya koymuş olsa da, hukuki anlamda sonuçların istememektedir. Bu durum ise kastın olmadığının tespiti bakımından yeterlidir.”. Bu görüş kast ile saiki birbirine karıştırması nedeniyle eleştirilmektedir. Bkz. AKAR, İbrahim: "Tahrikçi Ajan”, Marmara Üniversitesi Hukuk Arașttrmaları Dergisi, 2018, Cilt 24, Sayı 1, s. 143.

265 SOYASLAN, Genel Hükümler, s. 493; İLTAȘ, s. 186. 
gibi kurumlarla açıklanmaktadır. Şüphesiz kanun hükmünü yerine getirme ve amirin emrini ifa biçimindeki cezasızlık hallerinden sadece kamu görevlisi sıfatı taşıyan kışkırtıcı ajanlar faydalanabilecek$\operatorname{tir}^{266}$.

Türk ceza hukukunda kışkırtıcı ajan ya da benzeri bir adla açık bir düzenlemeye yer verilmemiştir. Yalnızca Ceza Muhakemesi Kanunu'nun (CMK) 139. maddesinde gizli soruşturmacı adı altında bir düzenleme bulunmaktadır. CMK'nın 139. maddesinde düzenlenen gizli soruşturmacı faaliyetinin kışkırtıcı ajan faaliyeti olarak nitelendirilmemesi gerektiği zira gizli soruşturmacının, suça karışmamış veya hakkında herhangi bir kuşku bulunmayan kişileri suç işlemeye yöneltemeyeceği sadece delil ve bilgi toplayabileceği ifade edilmektedir ${ }^{267}$. Bununla birlikte gizli soruşturmacının, hangi amaçla olursa olsun, başkalarını suç işlemeye teşvik etmesi ya da azmettirmesi hallerinde kışkırtıcı ajan olarak kabul edilerek cezalandırılması gerektiği ${ }^{268}$, başkasında bulunan suç işleme eğilim veya kararını destekleyici hareketlerin ise suç teşkil etmeyeceği belirtilmektedir ${ }^{269}$.

Yüksek Mahkeme belirli suçların soruşturulmasında gizli soruşturmacının kullanılmasını belli şartlara bağlamıştır. Önemle belirtmek gerekir ki, Yüksek Mahkeme yalnızca CMK'nın 139. maddesinde belirtilen suçlar yönünden değil, fuhuş ve benzeri suçlar yönünden de gizli soruşturmacının görevlendirilebileceği görüşündedir. Bu gibi suçlar söz konusu olduğunda gizli soruşturmacının görevlendirme dayanağı CMK'nın 160 vd. maddeleridir. CMK'nın 160. maddesine göre görevlendirilen kolluk gücüne "gizli soruşturma yapan adli kolluk görevlisi" denmektedir ve bu kişiler vasitasıyla elde edilen delillerin hukuka uygun kabul edilebilmesi için belli şartların mevcudiyeti gerekir: Gizli soruşturma yapan kamu görevlisi öncelikle CMK'nın 160 vd. maddeleri uyarınca Cumhuriyet Savcısı tara fından yazılı veya acele hallerde sözlü olarak görevlendirilmiş olmalıdır. Başka bir ifade ile gizli soruşturma faaliyetini yetkili adli birimin gözetiminde gerçekleştirmelidir. Diğer bir şart ise gizli soruşturma yapan adli kolluk görevlisi hiçbir zaman kışkırtıcı ajan gibi hareket etmemeli, önceden failde bulunmayan suç işleme kastını yaratarak faili suç işlemeye teşvik ya da azmettirmemelidir. Gizli soruşturmacının suça ilişkin tutanağı delil olarak dosya içerisine girmiş ise tanık koruma kuralları gözetilerek dinlenmeli, sanığa gizli soruşturma yapan adli kolluk görevlisinin beyanlarına karşı savunma yapma imkânı tanınmalıdır ${ }^{270}$. UUMITT suçunun soruşturulmasında da CMK 160 vd. maddeleri uyarınca görevlendirilme yapılabilir. Yüksek Mahkemeye göre CMK'nın 139. maddesinde sayılan suçlar yönünden ${ }^{271}$, adli kolluk görevlisi olmayan kişiler de hâkim kararı ile gizli soruşturmacı olarak görevlendirilebilir. UUMİT suçu CMK'nın 139. maddesinde sayıldığından, bu suç yönünden adli kolluk görevlisi olmayan kişilerin de gizli soruşturmacı olarak görevlendirilebileceği sonucu çıkmaktadır ${ }^{272}$. Ancak CMK'nın 139. maddesinin 1. fikrasında "kamu görevlileri gizli soruşturmacı olarak görevlendirilebilir" ifadesinin yer alması nedeniyle gizli soruşturmacı adli kolluk görevlisi olmasa dahi muhakkak kamu görevlisi olmak zorundadır.

Gizli soruşturmacı faaliyeti çerçevesinde yapılsa da uyuşturucu madde satın alınmak istenmesi halinde gizli soruşturmacı yönünden esasen azmettirme ya da suça teşvik etme durumu söz konusu olduğu düşüncesindeyiz. Bununla birlikte gizli soruşturmacı kullanılması, bazı suçların ve suçluların açığa çıka

\footnotetext{
266 AKAR, s. 141

267 ARTUK / GÖKCEN / ALŞAHİN / ÇAKIR, s. 696; CENTEL / ZAFER / ÇAKMUT, s. 500; ÖNDER, s. 466.

268 İÇEL, s. 553.

269 SOY ASLAN, Genel Hükümler, s. 494.

270 Yargitay, CGK., T. 13.03.2018, E. 2017/18-207, K. 2018/96.

271 Bu suçlar CMK'nın 139. maddesinin 7. fıkrasında sayılmıștır: Türk Ceza Kanunu'nda yer alan; örgüt faaliyeti çerçevesinde işlenip işlenmediğine bakılmaksızın UUMİT suçu (madde 188), suç işlemek amacıyla örgüt kurma (iki, yedi ve sekizinci fikralar hariç, madde 220), 6136 sayılı Kanun madde 12 ve 2863 sayılı Kanun'un 68 ve 74. maddesinde sayılan suçlar.

272 Yargitay, CGK., T. 30.01.2020, E. 2017/10-721, K. 2020/42: “... suç tarihi itibariyle gizli soruşturmacı ancak TCK’nın 220. maddesinin birinci fikrasında tanımlanan 'örgüt kurma' ve 'örgüt yönetme' suçları ile örgüt faaliyeti çerçevesinde işlenmiş olması sartıyla CMK'nın 139. maddesinde sınırlı olarak sayılan diğer suçlar için görevlendirilebilir. Bunlar dışındaki suçlar nedeniyle görevlendirilen gizli soruşturmacı 'adli kolluk görevlisi değil ise' topladı̆̆ deliller hukuka aykırıdır.".
} 
rılması yönünden gereklilik arz etmektedir. CMK'nın 139/1 hükmüne göre gizli soruşturmacı görevlendirilebilmesi için "soruşturma konusu suçun işlendiği hususunda somut delillere dayanan kuvvetli şüphe sebeplerinin bulunması ve başka surette delil elde edilememesi” şartlarının bir arada gerçekleşmesi ge rekli olsa da neticede kurmaca alıcı rolündeki gizli soruşturmacının faaliyeti suça azmettirme ve teşvik etme niteliğindedir. Elde edilen delilin hukuka uygun kabul edilebilmesi ve gizli soruşturmacının gerçekleştirmiş olduğu faaliyet yönünden cezasızlığı hak edebilmesi için hukuk devletine bağdaşır ilkelerin belirlenmesi ve bu ilkeler çerçevesinde delillerin hukuka uygun olup olmadığının belirlenmesi gerekmektedir. Avrupa İnsan Hakları Mahkemesinin bu konuya ilişkin vermiş olduğu kararlardan bazı ilke ve kriterler çıkarmak mümkündür: Öncelikle sanığın, gizli soruşturmacının teşviki olmadan da suç işleye ceği emarelerinin bulunması gerekmektedir ${ }^{273}$. Sanığın sabıkasının bulunması tek başına suç işleme eğiliminin olduğunu göstermez ${ }^{274}$. Gizli soruşturmacı kurmaca alıcı rolündeyken satıcıya baskı yapmamalıdır. Nesnel bir şüphe yokken satıcı ile irtibata geçilmesi ${ }^{275}$, satıcının önce reddetmesine rağmen gizli soruşturmacının teklifini yineleyici hareketlerde bulunmass ${ }^{276}$, satılan maddeye ilişkin olarak ortalamanın üzerinde fiyat teklif edilmesi ${ }^{277}$, uyuşturucu veya uyarıcı madde yoksunluğundan bahsederek satıcının merhametine hitap edilmesi ${ }^{278}$ bask1 yapma kapsamında değerlendirilmektedir ${ }^{279}$.

CMK'nın 139. maddesinin 5. fikrasında yer alan "gizli soruşturmacı görevini yerine getirirken suç işleyemez" hükmü dikkate alındığında gizli soruşturmacının, gerçekleştirmiş olduğu faaliyet yönünden sorumlu tutulmaması için mevzuattaki düzenlemelerin yeterli olmadığı düşüncesindeyiz. $\mathrm{Bu}$ nedenle uyuşturucu veya uyarıcı madde suçlarında görev alan gizli soruşturmacının yürüttüğü faaliyet nedeniyle sorumlu tutulmaması için hukuk devleti ile bağdaşır şartlar belirlenerek kanun hükmü ile özel bir hukuka uygunluk nedeni yaratılabilir ${ }^{280}$.

UUMIT suçuna iştirak edenlerin tespiti için, uyuşturucu veya uyarıcı niteliğindeki maddenin, yetkili makamın bilgisi ve denetimi altında ülkeye girişine, ülke içinde nakline ya da ülke dışına çıkarılmasına izin verilebilmektedir. Kontrollü teslimat denilen bu yöntemde, uyuşturucu veya uyarıcı maddeyi teslim alanlar tespit edilerek suça iştirak edenlerin ortaya çıkarılması hedeflenmektedir. Yetkili makamlar bunun gibi bir faaliyette esasen pasif kalmaktadır. Ancak bu ihmali davranış hem kanundan hem de uluslararası sözleşmeden kaynaklanmaktadır ${ }^{281}$ ve iştirak iradesi bulunmadığından izin verilen fiilden dolayı yetkili mercilerin cezai sorumlulukları bulunmamaktadır. Kontrollü teslimat hallerinde, kışkırtıcı ajan faaliyetinde olduğu gibi, yetkili makamın aktif bir davranışı söz konusu olursa bu dav-

273 AïHM, Teixeira de Castro, B. No: 25829/94, T. 09.06.1998, § 37-38, (kaynak ve çeviri için bkz. Avrupa İnsan Hakları Mahkemesi, 6. Madde Rehberi Adil Yargılanma Hakkı (Ceza Hukuku Yönü) (https://www.echr.coe.int/Documents/Guide_Art_6_criminal_TUR.pdf, E.T.: 22.07.2021), s. 48.

274 AïHM, Constantin ve Stoian, B. No: 23782/06-46629/06, T. 29.09.2009, § 55, (kaynak ve çeviri için bkz. Avrupa İnsan Hakları Mahkemesi, 6. Madde Rehberi Adil Yargilanma Hakk1-Ceza Hukuku Yönü, s. 48).

275 AïHM, Burak Hun, B. No: 17570/04, T. 15.12.2009, § 44, (kaynak ve çeviri için bkz. Avrupa İnsan Hakları Mahkemesi, 6. Madde Rehberi Adil Yargılanma Hakkı-Ceza Hukuku Yönü, s. 48).

276 AİHM, Ramanauskas, B. No: 74420/01, T. 05.02.2008, § 11 ve 67, (kaynak ve çeviri için bkz. Avrupa İnsan Hakları Mahkemesi, 6. Madde Rehberi Adil Yargılanma Hakkı-Ceza Hukuku Yönü, s. 48).

277 AïHM, Malininas, B. No: 10071/04, T. 01.07.2008, § 37, (kaynak ve çeviri için bkz. Avrupa İnsan Hakları Mahkemesi, 6. Madde Rehberi Adil Yargılanma Hakkı-Ceza Hukuku Yönü, s. 48).

278 AïHM, Vanyan, B. No: 53203/99, T. 15.12.2005, § 11 ve 49, (kaynak ve çeviri için bkz. Avrupa İnsan Hakları Mahkemesi, 6. Madde Rehberi Adil Yargılanma Hakkı-Ceza Hukuku Yönü, s. 48).

279 Tüm metnin çevirisi için bkz. Avrupa İnsan Hakları Mahkemesi, 6. Madde Rehberi Adil Yargılanma Hakkı (Ceza Hukuku Yönü) s. 48.

280 Özellikle kışkırtıcı ajanın suça kurmaca alıcı olarak katıldı̆̆ı hallerde, gerçek satın alma iradesinin olmadığı görüşü bazı itirazlara uğra yınca, İtalyan yasa koyucunun belirli malların kurmaca alınması durumuna ilişkin özel bir hukuka uygunluk nedeni oluşturma yoluna gittiği ifade edilmektedir. Bkz. TAŞKIN, s. 194.

281 Türkiye'nin de taraf olduğu "1988 tarihli Uyuşturucu ve Psikotrop Maddeler Kaçakçıllı̆̆na Karşı BM Sözleşmesi”nde, “4208 sayılı Kara Paranın Aklanmasının Önlenmesi Hakkında Kanun”da ve bu Kanun’a dayanılarak çıkarılan 1997 tarihli Yönetmelik’te kontrollü teslimata ilişkin düzenlemeler yer almaktadır. Uluslararası boyuttaki UUMïT suçu ile mücadelede bu konu, ülkeler arasındaki adli yardımlaşma kapsamında incelenmektedir. Bkz. TEZCAN, Durmuş / ERDEM, Mustafa Ruhan / ÖNOK, Murat: Uluslararası Ceza Hukuku, 3. Baskı, Seçkin Yayınevi, Ankara, 2015, (Uluslararası Ceza), s. 167. 
ranışın nedensellik bağını kesmemiş ve sonucu etkilememiş olması gerekmektedir ${ }^{282}$. Aksi halde elde edilen delil hukuka aykırı olabilecektir.

\section{E. Uyuşturucu veya Uyarıcı Madde Suçunun Üç veya Daha Fazla Kişi ile İşlenmesi ve Suç İşlemek İçin Teşkil Edilmiş Bir Örgütün Faaliyeti Çerçevesinde İşlenmesi}

Uyuşturucu veya uyarıcı madde ticareti suçunun çoğu kere organizasyon çerçevesinde gerçekleştirildiği, organizasyon halinde bu suçun işlenmesinin hem büyük kolaylık sağladığı hem de esas yöne ticiye ulaşılmasını zorlaştırarak organizasyonun çökertilmesini güçleştirdiği, bu nedenle UUMITT suçunun iştirak halinde işlenmesinin ağırlaştırıcı neden sayılmasının yerinde ve hatta zorunlu olduğu ifade edil mektedir $r^{283}$.

TCK'nın 188/5 hükmünde “uyuşturucu veya uyarıcı madde suçunun ü̧̈ veya daha fazla kişi tarafindan birlikte işlenmesi durumunda cezanın yarı oranda artırılacağı" hüküm altına alınmıştır.

Yüksek Mahkeme bu ağırlaştırıcı nedenin uygulanabilmesi için UUMİT suçu tanımındaki seçimlik hareketlerden birinin üç veya daha fazla kişi ile yapılması ve hareketin aynı yönde olması yani faillerin aynı seçimlik hareket üzerinde ortak hâkimiyet kurmaları gerektiğine, farklı seçimlik hareketlerin farklı kişiler tarafından gerçekleştirilmesi durumunda bu ağırlaştırıcı nedenin uygulanmayacağına hükmetmektedi ${ }^{284}$. Nitekim Yüksek Mahkemece verilen bir kararda, suçun üç veya daha fazla kişi tarafindan birlikte işlenmesi nitelikli halinin oluşabilmesi için faillerin, TCK'nın 188. maddesinin 3. fikrasında sayılan "satan, satın alan veya nakleden" seçimlik hareketlerinden birini müşterek fail ola rak birlikte gerçekleştirmeleri ve bir eylem birlikteliği içerisinde aynı yönde hareket etmeleri gerektiğine; somut olayda sanı̆̆ın ele geçen esrarı veren konumunda olduğu, alıcı konumundaki diğer sanıkların uyuşturucu maddeyi kendi nam ve hesabına aldıkları, dolayısıyla müşterek fail sıfatıyla değil birbirinden bağımsız olarak hareket ettikleri sabit olduğundan sanıklar hakkında verilen cezadan TCK'nın 188/5 hükmü uyarınca artırım yapılamayacağına hükmedilmiştir ${ }^{285}$.

Müşterek failin, kendisinin katılımından önce tamamen tamamlanmış eylemlerden ötürü geçmişe yönelik bir sorumluluğu söz konusu olmayacaktır ${ }^{286}$. Yüksek Mahkeme, suç tanımındaki seçimlik ha reketlerden birinin gerçekleştirilmesi ile suçun tamamlandığını, sonrasında yapılan seçimlik hareketlerin başka bir suçu oluşturduğunu gözeterek böyle bir içtihat geliştirmiş olabilir. Ancak bu yöndeki görüşün seçimlik hareketli suçların özelliği ile ters düştügünü söylemek gerekir. Zira seçimlik hareketlerden birinin yapılması ile tamamının yapılması arasında suç sayısı bakımından fark yoktur ve tek suç oluşur. Bu seçimlik hareketlerden biri ya da birkaçı, birlikte suç işleme iradesine sahip başka kişiler tarafından, fiil üzerinde ortak hâkimiyet kurmak suretiyle gerçekleştirilebilir ve bu durumda tek bir suça iştirak söz konusu olacaktır. Bu nedenle uyuşturucu maddeyi ticari maksatla satın alan, satın alınan uyuşturucu maddeyi nakleden, nakledilen uyuşturucu maddeyi alıp bir başkasına satan kişiler arasında suçu birlikte işleme iradesi mevcut ise hepsinin müşterek fail olduklarının kabulü gerekir.

765 sayılı TCK döneminde uyuşturucu veya uyarıcı madde ticareti suçunun toplu halde işlenmesi ağırlaştırıcı neden olarak kabul edilmekte ve bu ağırlaştırıcı nedenin uygulanması için iki kişinin var-

\footnotetext{
GÜNGÖR / KINACl, s. 445-450.

ERMAN / ÖZEK, s. 291.

284 Bkz. Yargıtay, 20. CD., T. 24.04.2019, E. 2018/4080, K. 2019/2625: “TCK'nın 188/5. maddesinin uygulanabilmesi için TCK'nın 188/3, maddesinde öngörülen seçimlik hareketlerden birinin üç veya daha fazla kisi tarafindan birlikte gerçeklestirilmesi gerektiği, somut olayda sanıkların satışa arz eden diğer sanı̆̆ın ise nakleden konumunda oldukları, bu nedenle sanıkların suça TCK'nın 37. maddesi anlamında 'aynı yönde fiili birlikte gerçekleștiren' konumunda iştirak etmediklerinin anlaşılması karşısında sanıklar hakkında hükmolunan temel ceza üzerinden, kosullarl bulunmadı̆̆ halde, TCK'nın 188/5. maddesi uyarınca artırım yapılarak fazla cezaya hükmedilmesi...”. Ayrica bkz. Yargitay, 10. CD., T. 29.06.2021, E. 2020/13991, K. 2021/8213; Yargitay, 10. CD., T. 24.03.2021, E. 2020/21446, K. 2021/3906. Aynı doğrultuda görüs için bkz. KIDIL, s. 232-233. 
lı̆g 1 yetmekteydi ${ }^{287}$. 5237 sayılı TCK'nın 188/5 hükmü ile UUMİT suçunun iştirak halinde işlenmesi ağırlaştırıcı neden olarak kabul edilmiş ise de eski Kanun ile karşılaştırıldığında uygulanma şartları zorlaştırılmıştır. Yüksek Mahkeme de vermiş olduğu kararlarla bu maddenin uygulama alanını daha da daraltmaktadir.

Müşterek faillerden ikisinin cezai ehliyetinin bulunduğu, birinin ise isnat yeteneğinin bulunmadığ1 durumlarda çok failli suç niteliğindeki bu ağırlaştırıcı nedenin uygulanabileceği ifade edilmektedir ${ }^{288}$. Bununla birlikte faillerden biri, hukuka uygunluk sebebinin bulunmasından dolayı cezalandırılamıyorsa çok failli suçun oluşmayacağı belirtilmektedir ${ }^{289}$. TCK'nın 188/5 hükmünde çok failli suç tipinin oluşması ve cezanın arttırılabilmesi için faillerin belirlenmesi ve iştirak şekillerinin tespit edilmesi gerekmektedir. Nitekim ağırlaştırıcı nedenin uygulanması için asgari olarak bu üç kişinin de müşterek fail olması gerekir, bu üç kişiden biri yardım eden ya da azmettiren konumundaysa bu ağırlaştırıcı neden uygulanmaz ${ }^{200}$. Yüksek Mahkemenin uygulaması da bu yöndedir ${ }^{291}$. Bu yüzden müşterek fail olarak suça iştirak ettikleri düşünülen kişilerin belirlenmesi ve yapılacak yargılama ile sorumluluklarının tespit edilmesi gerekmektedir. Bununla birlikte Yüksek Mahkeme vermiş olduğu bir kararında sanığın diğer sanık ile kimlikleri tespit edilemeyen iki şahısla birlikte toplam dört kişi olarak ele geçirilen kokaini satışa arz ettiklerinin sabit olduğuna ve TCK'nın 188/5 hükmünün uygulama koşullarının oluştuğuna hükmetmiştir ${ }^{292}$.

TCK'nın 188/5 hükmüne göre “uyuşturucu veya uyarıcı madde ticareti suçunun, suç işlemek için teşkil edilmiş bir örgütün faaliyeti çerçevesinde işlenmesi halinde, verilecek ceza bir kat arttırlacak$t \imath{ }^{293 "}$. Örgüt kurma ve bu örgütün suç örgütü sayılabilmesi için hangi özellikleri taşıması gerektiği TCK'nın 220. maddesinde belirtilmiştir. Bir kereye mahsus olmak üzere üç veya daha fazla kişinin bir araya gelerek UUMITT suçunu işlemesi durumunda bu ağırlaştırıcı neden uygulanmaz. Burada belirleyici hususlardan biri söz konusu oluşumun devamlılı̆ğdır ${ }^{294}$. Müşterek faillikte suç ortakları nezdinde suçun konusu ve mağduru gibi unsurların somutlaşmış olması gerekirken örgütlü suçlar bakımından suçun konusu ve mağduru gibi unsurların somutlaşması mümkündür, ancak zorunlu değildir ${ }^{295}$.

TCK'nın 220. maddesinde düzenlenen suç örgütünün varlığı için, üye sayısının en az üç kişi olmasının, üyeler arasında soyut bir birleşme değil, gevşek de olsa hiyerarşik bir ilişkinin bulunmasının, suç işlenmese bile suç işlemek amacı etrafında fiili bir birleşmenin olmasının, niteliği itibariyle devamlılık göstermesinin, örgütün yapısı ve sahip bulunduğu üye sayısı ile araç ile gereç bakımından, amaçlanan suçları işlemeye elverişli olmasının gerektiği ifade edilmektedir ${ }^{296}$. Bu artııım nedeninin uygulanabilmesi için örgütün, özel olarak UUMiT suçunu işlemek için kurulmuş olması gerekli değildir227.

TCK'nın 220. maddesinin 7. fikrasında "Örgüt içerisinde hiyerarşik yapıya dâhil olmamakla birlikte, örgüte bilerek ve isteyerek yardım eden kişi, örgüt üyesi olarak cezalandırılır." hükmü yer al-

\footnotetext{
287 GÜNAL, S. 120-121.

288 YALÇIN SANCAR, s. 217; farklı yönde görüş için bkz. DÖNMEZER / ERMAN, s. 744.

289 DÖNMEZER / ERMAN, s. 744-745.

290 ZAFER, s. 412.

291 Bkz. Yargitay, 10. CD., T. 23.02.2021, E. 2020/12308, K. 2021/2567: “... diğer sanı̆̆ın etrafi gözetlemek suretiyle yardım eden sifattyla suça iş̧tirak ettiğinin anlaşılması karşısında sanıklar hakkında hükmolunan temel ceza üzerinden, koşulları bulunmadığı halde, TCK'nın 188/5. maddesi uyarınca artırım yapılarak fazla cezaya hükmedilmesi,”. Ayrıca bkz. Yargıtay, 10. CD., T. 05.11.2020, E. 2020/6287, K. 2020/6865.

292 Bkz. Yargitay, 10. CD., T. 24.09.2020, E. 2020/5755, K. 2020/4274.

293 TCK'nın 188/5 hükmünde de düzenlenen ağırlaştırıcı nedenin sadece 188. maddenin 1. ve 3. fikrası için geçerli olduğu, 188. maddenin 7. fikrasında düzenlen suç yönünden uygulanamayacağı ifade edilmektedir. Bkz. YOLCU, s. 98.

294 Bkz. Yargitay, 10. CD., T. 27.09.2018, E. 2018/3166, K. 2018/6534: “... örgüt oluşturmak için gerekli olan sayı mevcut ise de sanıklar arasında hiyerarşik bir ilişki ve suç işleme hususundaki devamlılık saptanamamıștır.".

295 İLTAS, s. 235.

296 Bkz. Yargitay, 10. CD., T. 27.09.2018, E. 2018/3166, K. 2018/6534; AKKAY A, s. 57.

297 YOLCU, s. 94
} 
maktadır ${ }^{298}$. Bu hükümden yola çıkılarak hiyerarşik yapıya dâhil olmayan ve örgüte bilerek ve isteye rek yardım eden kişiler hakkında hem TCK'nın 220. maddesinde hem de TCK'nın 188. maddesinin 1. veya 3. fikrasında düzenlenen suçlar yönünden ceza verileceği, verilen cezadan TCK'nın 188/5 hükmü uyarınca artırım yapılacağı ifade edilmektedir ${ }^{299}$. UUMIT suçunu işleyen bir örgüte maddede sayılan seçimlik hareketlerden hiçbirini yapmadan yardım eden kişinin hem fail gibi cezalandırılması hem de ağırlaştırıcı nedenin uygulanması ve bunun yanında bir de suç örgütü üyeliğinden ceza alması, cezala rın şahsiliği ilkesine aykırılık teşkil etmektedir ${ }^{300}$.

Suçun suç işlemek için teşkil edilmiş bir örgütün faaliyeti çerçevesinde işlenmesi halinin UUMITT suçu yönünden ağırlaştırıcı neden sayılması nedeniyle faile hem uyuşturucu veya uyarıcı imal ve ticareti suçundan hem de örgüt üyeliği suçundan ceza verilmesi TCK'nın 42. maddesinde düzenlenen bileşik suç hükmüne aykırılık teşkil etmektedir. Her iki suçtan dolayı ceza verilmesi TCK'nın 220. maddesinin 4. fikrasına dayandırılsa ${ }^{301}$ da bu hüküm, suçun örgüt faaliyeti çerçevesinde işlenmesini ağırlaştırıcı neden olarak kabul etmeyen diğer suçlar için geçerli olmalıdır ${ }^{302}$. En doğru çözüm, örgütün varlığının tespitinde TCK'nın 220. maddesinin esas alınması, UUMITT suçunun bir örgüt faaliyeti çerçevesinde işlendiği tespit edildiğinde sadece TCK'nın 188. maddesinin uygulanması ve 5. fikra uya rinca da artırım yapilmasidır.

UUMITT suçunun terör örgütü faaliyeti çerçevesinde işlenmesi halinde TCK'nın 188/5 hükmüne göre değil, Terörle Mücadele Kanunu'nun (TMK) 5/2 hükmüne göre artırım yapılacaktır. Ancak farklı görüşte olanlar da bulunmaktadır. TMK'nın 5/2 hükmünde yer alan "yapılacak artırım cezanın üçte ikisinden az olamaz" ifadesinden yola çıkılarak, UUMiT suçunun terör örgütü faaliyeti çerçevesinde işlenmesi halinde cezanın sadece madde 188/5'e göre bir kat arttırılacağı, böyle bir artırım üçte ikiden fazla olduğundan bu noktada TMK'nın 5/2'nin son cümlesine uygun bir sonucun ortaya çıkacağı ifade edilmektedir ${ }^{303}$. Ancak TMK'nın 5/2 hükmünde yer alan hüküm açıktır. TMK'nın 5/2 hükmüne göre "suçun örgütün faaliyeti çerçevesinde işlenmiş olması dolaylsıyla ilgili maddesinde cezanın artırılması öngörülmüssse; sadece bu madde hükmüne göre ceza artırımı yapılacaktır". TMK'nın 5/1 hükmünde suçun terör örgütü faaliyeti çerçevesinde işlenmesi durumunda cezanın yarı oranında artırılacağı hür küm altına alınmıştır. TMK'nın 1 ve 2. maddesi birlikte değerlendirildiğinde, UUMITT suçunun terör örgütü faaliyeti çerçevesinde işlenmesi durumunda cezadan en çok üçte ikilik bir artırım yapılabilecektir. Bu durumda normal suç örgütlerine nazaran suçun terör örgütü faaliyeti çerçevesi içerisinde işlenmesi hallerinde faillere daha az ceza verileceği gibi bir sonucu ortaya çıkarmaktadır. Zira UUMITT suçu, TCK 220 kapsamına giren bir suç örgütü çerçevesinde işlenirse verilecek ceza bir kat arttırılacaktır.

\section{F. Suça Etki Eden Nedenlerin Diğer Suç Ortaklarına Geçişi}

Suçun niteliğini değiştirmeyip sadece suçun niteliğine etki eden, mevcudiyeti ile suçun daha çok ya da daha az ağır sayılmasını gerektiren ve etki ettiği suçun unsurları dışında kalan sebepleri, suça etki eden nedenler olarak tanımlamak mümkündür ${ }^{304}$. Suça etki eden nedenler, doğrudan gerçekleştiri-

\footnotetext{
298 İlgili hükümde "bilerek" ifadesine yer verildiğinden olası kastla bir suç örgütüne yardımda bulunmak mümkün değildir.

299 İLTAŞ, s. 234.

300 TCK’nın 220/7 hükmündeki gibi bir hüküm olmadan önce eylemi seçimlik hareketlerden birini oluşturmayan, sadece yardım niteliğindeki hareketlerde bulunan kişinin, örgüt halinde suç işlemiş olmayacağı, bu gibi hallerde örgütün temelini oluşturan anlaşmanın bulunduğunun kabul edilemeyeceği ve organizasyona dâhil olmayan şerik hakkında ağırlaştırııı neden uygulanmaması gerektiği ifade edilmekteydi. Bkz. ERMAN / ÖZEK, s. 303.

301 TCK'nın 220. maddesinin 4. fikrasında "örgütün faaliyeti çerçevesinde suç işlenmesi halinde, ayrıca bu suçlardan dolayı da cezaya hükmolunur." ifadesi yer almaktadır.

302 KURT YÜCEKUL, Gülşah: “Türk Ceza Kanunu'nun 220/4. Maddesinin, Bileşik Suçu Düzenleyen 42. Madde Karşısında Uygulanabilirliği Üzerine Bir Değerlendirme", Galatasaray Üniversitesi Hukuk Fakültesi Dergisi, 2010, Cilt 2, Sayı 1, Prof. Dr. Köksal Bayraktar’a Armağan, s. 1033.

303 KIDIL, S. 235

304 DÖNMEZER / ERMAN, s. 809.
} 
len fiilden kaynaklanabileceği gibi suçu gerçekleştiren failin şahsi durumundan da kaynaklanabilir ${ }^{305}$. Nitekim 765 sayılı TCK'nın yürürlükte olduğu dönemde suça etki eden nedenlerin diğer suç ortaklar1na sirayet edip etmeyeceğine ilişkin değerlendirme yapılırken bu ayrım esas alınarak belirleme yapılmaktaydı. 5237 sayılı TCK'da böyle bir düzenlemeye bilinçli olarak yer verilmemiş ve TCK'nın 40 . maddesinin gerekçesinde bu sorunun bağl1lık kuralı ile çözümlenmesi gerektiği ifade edilmiştir ${ }^{306}$.

Suça etki eden nedenin fiile mi, yoksa şahsa $\mathrm{m}$ ilişkin olduğunun kesin tespitinin yapılmasının her durumda mümkün olmadığı ${ }^{307}$; bu ayrımın belirsizliği nedeniyle 765 sayılı TCK' da yer alan hükme yeni Kanun'da yer verilmediği ve sorunun bağlılık kuralı ile çözülmesi gerektiği ifade edilmiş ise de öğretide çoğunlukla suça etki eden nedenlerin suç ortaklarına sirayeti konusu bu ayrım çerçevesinde incelenmekte ve bir sonuca ulaşılmaktadır ${ }^{308}$. Nitekim suça iştirak hükümlerinin esin kaynağ olan Alman Ceza Kanunu'nda bağlılık kuralı düzenlenmiş olmasına rağmen ayrıca 28. maddede, failin şahsi durumundan kaynaklanan cezaya etki eden nedenlerin diğer suç ortaklarına sirayeti ayrıca düzenleme altına alınmıştır ${ }^{309}$.

Suça etki eden nedenlerin şeriklere geçişini incelemeden önce belirtmeliyiz ki, müşterek faillik hallerinde her fail birbirinden bağımsız olarak, kendi şahsından ya da fiilinden kaynaklanan suça etki eden nedenler esas alınarak cezalandırılacaktır ${ }^{310}$. Suça etki eden neden failin şahsından kaynaklanıyorsa ve müşterek faillik söz konusu ise sadece kendisinde şahsa bağlı ağırlaştırıcı ya da hafifletici neden olan kişi hakkında artırım ya da indirim yapılacaktır.

Fiilden kaynaklanan hafifletici nedeninin varlığı halinde bilip bilmediğinin bir önemi olmaksızın bundan tüm failler ve şerikler faydalanır ${ }^{311}$. Nitekim uyuşturucu veya uyarıcı imal ve ticareti suçu yönünden Kanun'un 188/6 hükmünde cezayı hafifleten nedene yer verilmiştir. Suça konu olan uyuşturucu veya uyarıcı madde, "üretimi resmi makamların iznine veya satısı yetkili tabip tarafindan düzenlenen reçeteye bağlı olan ve uyuşturucu veya uyarıcı madde etkisi doğuracak nitelikteyse faile verilecek ceza yarı oranda azaltılacaktır ${ }^{312 "}$. Söz konusu hafifletici neden fiile ilişkindir ve diğer suç ortakları cezayı hafifleten bu nedeni bilmeseler dahi ceza onlar lehine de azaltılacaktır ${ }^{313}$. Şahıstan kaynaklanan hafifletici nedenin varlığı halinde ise bundan sadece bu şartın bulunduğu failler ya da şerikler faydala nir ${ }^{314}$.

305 Bkz. EKİCI ŞAHIN, Meral: “İștirak Halinde İşlenen Suçlarda Suça Etki Eden Nedenlerin Şeriklere Sirayeti”, Ankara Üniversitesi Hukuk Fakültesi Dergisi, 2015, Cilt 64, Sayı 3, s. 654: “... suça etki eden fiili nedenler, suçun temel şeklini değiştirmemekle birlikte, suçun daha ağır veya daha hafif sayılmasına yol açan, suçun işlenişs şekli, zamanı, netice, suçun işlenmesinde kullanılan araçlar ve fiille netice arasındaki illiyet bağından kaynaklanan nedenlerdir. Bununla birlikte sahsi nedenler, failin veya șerikin şahsindan, onlarl suç işlemeye sevk eden özel amaç veya saiklerden, faille mağdur veya şerikle mağdur arasındaki özel iliş̧kiden kaynaklanır.".

306 Bkz. TCK 40 Madde Gerekçesi: "Bağlllık kuralına metinde yer verildikten sonra, bu hükümlerin korunmasina gerek kalmamıştır.". Bu sorunu çözmede "bağlılık kuralı" (TCK m. 40) ve "hata" (TCK m. 30) hükümlerinin yeterli olduğu ifade edilmektedir. Bkz. ARTUK / GÖKCEN / ALŞAHIN / ÇAKIR, s. 688 vd.

307 Bkz. TCK 40 Madde Gerekçesi: “... kaldı ki, ağırlaştırıcı nedenlerin, kişisel veya fiili olarak ayrıma tabi tutulması bilimsel olmadı̆̆ için, uygulamada duraksamalara ve çelişkili kararlara neden olmaktadır.".

308 Bkz. DEMIREL, Bağlllık Kuralı, s. 489: “... bu konudaki kanaatimiz, bir nedenin cezaya etki etme sebebinin haksızlı̆ga ya da kusura mı etki ettiğinin büyük önemi haiz olmasından hareketle nitelikli hallerin fiile mi yoksa şahsa mı bağlı olduğunun belirlenmesinin zorunlu olduğu yönündedir.”. Alman hukukunda bu ayrımın kaldırılmadığı ifade edilmektedir. Bkz. ÖZBEK / DOĞAN / BACAKSIZ, s. 523.

309 Bkz. YENISEY, Feridun / PLAGEMANN, Gottfried: 15 Mayls 1871 tarihli Alman Ceza Kanunu, Beta Yayınevi, İstanbul, 2009, s. 22. Alman Ceza Kanunu’nun 28. maddesinin 1. fikrasında; “... failin cezalandirllabilmesinin sebebini teşkil eden özel kişisel unsurlar şerikte yoksa bu kisinin cezast 49 'uncu maddenin l'inci fikrast uyarınca indirilir" 2. fikrasında "kanun, özel kisisisel unsurlar nedeniyle cezayl arttırmayl, indirmeyi veya sanığa ceza verilmesine yer olmadı̆̆ına karar vermeyi öngörmüssse, bu düzenleme sadece bu tür özel nitelikleri şahsında gerçekleştirmiş bulunan suç ortağı hakkında uygulanır." hükümleri yer almaktadır.

310 TAŞKIN KAPUSUZOĞLU, s. 156.

311 EVIK, s. 176.

312 Reçete ile satılması gereken uyuşturucu veya uyarıcı niteliği bulunan maddelerin temini için yetkili doktorca düzenlenmiş kırmızı ve yeşil reçetenin gerekli olduğu belirtilmektedir. Bkz. ÖZDABAKOĞLU, s. 126.

313

DÖNMEZER / ERMAN, s. 815

314 AYDIN, s. 232. 
Cezayı ağırlaştıran nitelikli hallerin suçun maddi unsurunun bir parçası olduğu, nitelikli halin sur çun maddi unsuru içerisinde yer alması nedeniyle hem failin hem de şerikin kastının kapsamında olması gerektiği, hem failin hem de şerikin kastının kapsamında olması halinde her ikisinin de suçun nitelikli halinden, yalnızca failin kastının kapsamında olması halinde failin nitelikli halden, şerikin ise suçun basit halinden sorumlu olması gerektiği ifade edilmektedir ${ }^{315}$. Başka bir ifade ile şerikin suçun nitelikli halini gerçekleştirildiğini bilmesi durumunda cezayı ağırlaştırıcı neden ister failin fiilinden isterse şahsından kaynaklansın şerik için de uygulanacaktır. Bunun yanında failde bulunan şahsa bağlı ağırlatıcı nedenin, kendisinde şahsa bağlı ağırlaştırıcı neden bulunmayan şerike sirayet etmesinin ada letsiz sonuçlar doğurduğu, ancak bu adaletsiz durumun temel ceza belirlenirken dikkate alınıp kendisinde şahsa bağlı ağırlaştırıcı neden bulunmayan şerike daha az ceza verilerek giderilebileceği ifade edilmektedir ${ }^{316}$. Nitekim TCK'nın 188/8 hükmünde failin şahsından kaynaklanan ağırlaştırıcı nedene yer verilmiştir. Eğer uyuşturucu madde ticareti yapma suçu ilgili hükümde sayılan kişiler tarafından işlenirse verilecek ceza yarı oranda arttırılacaktır ${ }^{317}$. Bir eczacının uyuşturucu veya uyarıcı madde imal ve ticareti suçuna azmettirilmesi ya da eczacının işlemiş olduğu böyle bir suça yardım edilmesi durumunda, suçu gerçekleştirenin eczacı olduğunu biliyorlarsa azmettiren ya da yardım eden hakkında TCK'nın 188/8 hükmü uygulanacak, başka bir ifade ile nitelikli hal şeriklere de sirayet edecektir ${ }^{318}$. Ancak şerikler hakkında temel ceza belirlenirken bu durum göz önünde bulundurularak ceza hafifletilebilecektir.

TCK'nın 188/8 hükmünde düzenlenen şahıstan kaynaklanan ağırlaştırılmış halin aynı zamanda özgü suç niteliğinde olduğu ifade edilmektedir ${ }^{319}$. TCK'nın 40/2. maddesinde yer alan hükme göre “özgü suçlarda, ancak özel faillik niteliğini taşıyan kişi fail olabilir. Bu suçların işlenmesine iştirak

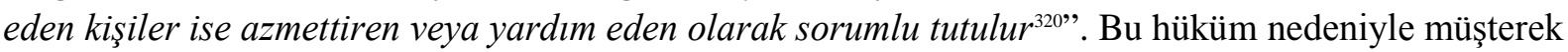
faillik durumunda sadece TCK'nın 188/8 hükmünde sayılan mesleklerden birini ifa eden fail hakkında bu nitelikli hal uygulanacak, diğer müşterek failler ise suçun basit şeklinden sorumlu tutulacaktır ${ }^{321}$.

TCK'nın 188. maddesinin son cümlesinde uyuşturucu veya uyarıcı madde verilen veya satılan kişinin çocuk olması halinde veren veya satan kişiye daha yüksek hadden ceza verileceği hüküm altına alınmıştır. TCK'nın 6/1-b hükmüne göre "çocuk deyiminden, henüz on sekiz yaşını doldurmamış kişi" anlaşılacaktır. Bu durumda uyuşturucu veya uyarıcı maddenin satıldığı veya verildiği kişinin bu fiiller icra edildiğinde on sekiz yaşını doldurmamış olması gerekmektedir ${ }^{322}$. Uyuşturucu veya uyarıcı madde temin edildiği kişinin çocuk olduğu bilinmiyorsa fiil üzerinde hata söz konusu olabilir ve ağırlaştırıcı neden uygulanmayabilir. Suça iştirak edenler hakkında fiilden kaynaklanan bu ağırlaştırıcı nedenin uygulanabilmesi için, fail tarafından uyuşturucu veya uyarıcı madde verilen veya satılan kişinin on sekiz yaşının altında bir çocuk olduğunun diğer suç ortakları tarafından bilinmesi gerekmektedir.

Uyuşturucu madde ticareti yapma suçu bakımından TCK'nın 188/4 hükmünde yine fiile bağlı cezayı ağırlaştıran nedenlere yer verilmiştir. Ele geçirilen uyuşturucu maddenin TCK'nın 188/4-a hük-

315 TAŞKIN KAPUSUZOĞLU, s. 159.

316 Alman Ceza Kanunu'nda olduğu gibi şerikin cezasından indirim öngören bir hükme yer verilmediği için böyle bir uygulama yapılması önerilmektedir. Bkz. DEMIREL, Bağlllık Kuralı, s. 524.

$317 \mathrm{Bu}$ nitelikli halin uygulanabilmesi için hükümde sayılan sıfatların resmen kazanılmış olunması gerektiği, sayılan işlerden birinin fiilen yapılıyor olmasının bu nitelikli halin uygulanması için yeterli olmadığı, ayrıca resmi sıfata sahip bu kişilerin suçun işlendiği sırada bu mesleği fiilen yapması gerektiği, emekli bir doktorun bu suçu işlemesi durumunda bu nitelikli halin uygulanmayacağı ifade edilmektedir. Bkz. TEZCAN / ERDEM / ÖNOK, Ceza Özel Hukuku, 2019, s. 914.

318 BkZ. ERMAN / ÖZEK, s. 304

319 ÖNER, S. 158.

320 Özgü suçlar “bizzat işlenebilen özgü suçlar” ve "başkası aracılığı ile işlenebilen özgü suçlar” olarak ayrılmaktadır. Bkz. EVİK, s. 329. Bu hükmün, yalnızca bizzat fail tarafından işlenebilen özgü suçlar için geçerli olması gerekirdi.

321 Kanun koyucunun yapmış olduğu bu düzenleme nedeniyle özgü suçlarda, özel faillik sıfatı taşımayan kimseler bu suça iştirak ettiklerinde ancak şerik olarak sorumlu olabilecekleri ifa edilmektedir. Bkz. EVIK, s. 332. Bu durumda özel sıfatı taşımayan kişi hem suçun basit şeklinin müşterek faili hem de nitelikli halinin azmettireni ya da yardım edeni olarak kabul edilecektir. Failliğin şerikliğe asliliği kuralı gereği faili, sadece suçun basit şeklinden sorumlu tutmak gerekecektir.

GÜNAL, s. 129; SELBES, s. 151. 
münde sayılan uyuşturucu maddelerden biri olması durumunda faile verilecek ceza ağırlaştırılacaktır. Diğer suç ortaklarının bu ağırlaştırıcı unsuru bilmeleri, yani suçu nitelikli hale getiren türden madde nin imal ve ticaretinin yapıldığından haberdar olmaları gerekir. Nitelikli halden haberdar olmaları halinde ceza onlar içinde ağırlaştırılacak, bilmemeleri halinde ise artırım yapılması söz konusu olma yacaktır ${ }^{323}$.

Yine uyuşturucu madde ticareti yapma suçunun TCK'nın 188/4-b maddesinde belirtilen yerlere iki yüz metreden yakın ve umumi veya umuma açık bir yerde işlenmesi halinde ceza arttırılacaktır ${ }^{324}$. Diğer suç ortaklarına fiilden kaynaklanan bu ağırlaştırıcı nedenin uygulanabilmesi için UUMIT suçunun TCK'nın 188/4-b hükmünde sayılan yerlere iki yüz metreden yakın ve umumi veya umuma açık yerde işlendiğini bilmeleri gerekmektedir. Bilmemeleri halinde artırım yapılması söz konusu olmayacaktır.

Suça etki eden ağırlaştırıcı nedenin failde değil de şerikte bulunması halinde sadece şerikin kendisi bakımından etki etmesinin gerektiği, bu gibi bir durumda nitelikli halin şerikten faile sirayet etmeyeceği ifade edilmektedir ${ }^{325}$. Bir eczacının bir başkasını uyuşturucu veya uyarıcı madde imal ve ticaret suçuna azmettirmesi ya da bu suça yardım etmesi durumunda, TCK'nın 188/8 hükmü yalnızca azmettiren ve yardım eden sıfatını taşıyan eczacıya uygulanacak, azmettirilen ya da yardım edilen fail, sur çun basit şeklinden sorumlu olacaktır.

Suça etki eden nedenin, sonuç olarak, ceza üzerinde etkili olduğu, ancak suça etki eden neden ile cezayı etki eden neden arasında farklılığın bulunduğu ifade edilmektedir ${ }^{326}$. Uyuşturucu veya uyarıcı imal ve ticareti suçu yönünden getirilen ve Kanun'un 192. maddesinin 1. ve 3. fikrasında düzenlenen etkin pişmanlık hükmü cezaya etki eden nedendir ve bundan sadece etkin pişmanlık şartlarını yerine getiren failler ya da şerikler faydalanacaktır ${ }^{327}$. Nitekim TCK'nın 40. maddesinin 1. fikrasının son cümlesinde yer alan "suçun işlenişine iştirak eden her kişi, diğerlerinin cezalandırılmasını önleyen kişisel nedenler göz önünde bulundurulmaksızın kendi kusurlu fiiline göre cezalandırılır" hükmünden de aynı sonuca ulaşmak mümkündür.

\section{SONUÇ}

Dünya üzerindeki birçok ülke, bireylerin zararlı uyuşturucu veya uyarıcı maddelere ulaşmalarını ve bu maddeleri kullanmalarını önlenmek için mücadele vermektedir. Ortak akı1, tıbbi gereksinimler dışında kullanılan uyuşturucu veya uyarıcı maddelerin özelde insana, genelde topluma ve hatta tüm insanlığa zarar verdiğinde hem fikirdir. Ancak bu olgunun kişi hak ve özgürlüklerini ilgilendiren bir boyutu da bulunmaktadır. Kişi kendi bedeni ve geleceği üzerinde serbestçe tasarrufta bulunabilir. Devletterin bu alana müdahalesi kişi özgürlüğüne müdahale olarak algılanmaktadır. Ölebileceğini bilmesine rağmen kişinin uyuşturucu veya uyarıcı madde kullanması kendi tercihi denilebilir. Ama uyuşturucu veya uyarıcı madde kullanımı sadece kişiye etki etmemekte, özellikle yaygın olarak kullanımının toplum üzerinde olumsuz etkileri bulunmaktadır. Uyuşturucu veya uyarıcı madde kullanan kişiler, bazı durumlarda davranışlarını kontrol yeteneğini kaybederek suç işlemekte ve bu nedenle toplum düzeni bozulabilmektedir. Kendi ülkemiz özelinde söylemek gerekirse uyuşturucu veya uyarıcı madde krizine giren kişinin, bu maddeyi alabilmek için hırsızlık, yağma gibi suçları gerçekleştirdiği hadiselerle sıklıkla karşılaşılmakta-

323 ÖNDER, s. 472. Ayrıca tahmin etmenin bilmek olmadığı ifade edilmektedir. Bkz. YOLCU, s. 101.

$324 \mathrm{Bu}$ ağırlaştırıcı nedenin uygulanabilmesi için esas fiili işleyen failin de, iki yüz metre mesafede; okul, yurt, hastane, kışla veya ibadetha ne gibi tedavi, eğitim, askeri ve sosyal amaçlı toplu bulunan bina ve tesislerin var olduğunun bilincinde olması gerekmektedir.

325 DEMIREL, Bağlılık Kuralı, s. 527-528.

326 EKİCİ ŞAHİN, s. 652.

327 Malvarlığına karşı suçlar yönünden getirilen ve TCK'nın 168. maddesinde yer alan etkin pişmanlık hükmü yönünden Yüksek Mahkemenin farklı bir uygulama geliștirdiğini söylemek mümkündür. Bkz. Yargıtay, CGK., T. 23.05.2017, E. 2017/6-88, K. 2017/290: “iștirak halinde işlenmiş suçlarda fail, yardım eden veya azmettiren suç ortaklarından birinin mağdurun zararını tamamen gidermesi halinde, artık giderilmesi gereken bir zarar bulunmadığından zararı gidermeyen diğer suç ortakları yönünden etkin pişmanlık müessesesinin uygulanması için 'iade ve tazmin' şartı aranmayacak ise de, TCK'nın 168. maddesi tazminden çok pişmanlık esasına dayandiğından zararı gidermeyen diğer suç ortaklarının en azından pişmanlıklarını ya da iade ve tazmine rıza gösterdiklerini ortaya koyacak söz veya davranışlarda bulunmaları gerekmektedir.". 
dır. Yine toplum için tehlike oluşturan yasa dışı örgütlerin ve terör organizasyonlarının, uyuş̧turucu ve uyarıcı madde imal ve ticareti yoluyla finansmanlarını sağladıkları bilinmektedir.

Devletin insanı, kendisine karşı korumakla ilgili bir yükümlülüğü bulunmadığı iddia edilebilecekse de toplum düzenini sağlamakla ilgili bir yükümlülügünün bulunduğu her halde söylenebilir. $\mathrm{Bu}$ yönüyle uyuşturucu veya uyarıcı madde imal ve ticareti suçu ile mücadele etmek insanı, toplumu ve hatta tüm insanlığı korumak için vazgeçilmezdir. Bu mücadelede hassasiyet gösterilmesi gereken hur sus, bu suçla mücadele edilirken temel hak ve özgürlüklerin ihlal edilmemesi ve evrensel hukuk ilkele rine uygun olarak hareket edilmesidir.

Üretiminden nakline, depolanmasından satılmasına kadar her safhada birden çok insanın bu suçun işlenmesinde aktif olarak katkısı bulunmaktadır. Hatta bazı durumlarda faillerin bu birlikteliği devamılık arz eden organizasyonlara dönüşebilmektedir. Bu nedenle uyuşturucu ve uyarıcı madde imal ve ticareti suçuna iştirak konusu ayrı bir önem taşımaktadır. Uyuşturucu veya uyarıcı madde imal ve ticareti suçlarının cezasının çok ağır olması da göz önünde bulundurulduğunda, bu suçun işlenmesine katkı veren insanların hangi derece ve ağıllıkta sorumlu olacaklarının tespit etmek önem arz etmektedir.

Uyuşturucu veya uyarıcı madde imal ve ticareti suçu ile mücadelede esas olarak hedeflenen, bireylerin bu türden zararlı maddelere ulaşmalarını engellemektir. Başka bir ifade ile esas olarak yasaklanan bu maddelerin bireylere satışı ya da temin edilmesidir. Ancak kanun koyucu etkin mücadele için uyuşturucu maddelerin sadece bulundurulmasını -uyuşturucu madde kullanmak maksadiyla bulundur ruluyorsa daha hafif suç oluşacaktır- dahi satma ve temin etme hareketleri ile eşdeğer görerek ağır şekilde cezalandırılması iradesini ortaya koymuştur. Satıma ve temin etmeye ilişkin hareketlere yardım niteliğinde olan hareketleri yapanlar da fail olarak cezalandırılmaktadır. Uygulama göz önünde bulundurulduğunda, herhangi bir şekilde uyuşturucu veya uyarıcı madde ile temas halinde olan kişinin yardım eden değil, fail olarak cezalandırıldığını söylemek mümkündür.

İştirak halinde işlenen suçlar daha kolaylıkla işlenmektedir. Bu yüzden bazı suçlar yönünden suçun iştirak halinde işlenmesi ağırlaştırıcı neden olarak kabul edilmiş̧tir. Bu suçlardan biri de uyuşturucu veya uyarıcı madde imal ve ticareti suçudur. Yüksek Mahkemenin vermiş olduğu kararlar dikkate alındığında, bu ağırlaştırıcı nedeninin uygulanmasının zorlaştırıldığını söylemek mümkündür. Yüksek Mahkeme bu ağırlaştırıcı nedenin uygulanabilmesi için suça karışan en az üç kişinin de müşterek fail olmasını ve bu müşterek failliğin de aynı yönde olmasını aramaktadır. Uyuşturucu veya uyarıcı maddeyi nakleden, nakledenden alıp satan failler arasında müşterek failliğin oluşmayacağı, bu ağırlaştırıcı nedenin uygulanabilmesi için tek bir seçimlik hareketin, yani somutlaştırmak gerekirse sadece nakletme hareketinin, en az üç kişi ile müştereken gerçekleştirilmesi gerektiğine hükmedilmektedir. Yüksek Mahkemenin bu görüşünün seçimlik hareketli suçların özelliği ile bağdaşmadığını söylemek mümkündür.

Uyuşturucu ve uyarıcı madde imal ve ticareti suçuyla mücadelede sıklıkla kurmaca alıcı rolündeki kışkırtıcı ajan yöntemine başvurulmaktadır. Bu sadece ülkemize özgü bir faaliyet değildir ve başka ülkelerde de başvurulan bir yöntemdir. Kışkırtıcı ajanın, uyuşturucu madde satın alması nedeniyle suça iştirakten sorumlu olmaması ve somut olarak satın alma fiilinin, hükme esas alınabilecek hukuka uygun bir delil olarak kabul edilebilmesi için belli şartların gerçekleşmesi gerekmektedir. Hedefteki kişinin uyuşturucu ve uyarıcı madde imal ve ticareti suçunu işlediğine ilişkin emareler ve bu emarelerden kaynaklı kuvvetli suç şüphesi bulunmalıdır. Bizce kurmaca alıcı rolündeki kışkırtıcı ajanın mutlaka adli kolluk görevlisi olması ve görev yaptığı süreçte mutlak olarak savcılık ya da hâkimlik makamlarından aldığı direktiflerle yönlendirilmesi gerekmektedir. Kurmaca alıcının rolündeki kışkırtıcı ajanın hileli yollara başvurmaması gerekmektedir. Uyuşturucu ve uyarıcı maddenin bedelsiz olarak bir başkasına verilmesinin başlı başına suç oluşturduğu dikkate alındığında, kurmaca alıcının uyuşturucu madde yoksunluğu çektiğini belirterek bedelsiz olarak uyuşturucu madde istediği ve bunun üzerine kişinin de bedelsiz ola rak uyuşturucu maddeyi temin ettiği durumda kurmaca alıcı rolündeki kişinin davranışı hukuka uygun değildir. Zira bu davranış hedefteki kişiyi tuzağa düşürücü niteliktedir ve hilelidir. 
Kurmaca alıcı rolündeki kışkırtıcı ajanın topladığı delillerin hukuka uygun kabul edilmesi ve söz konusu yasadışı alım-satıma ilişkin fiile iştirak etmekten ceza almaması için başka ülkelerde olduğu gibi sıkı koşullar öngörülerek ve evrensel hukuk ilkeleri göz önünde bulundurularak özel bir hukuka uygunluk nedeni yaratılması yoluna gidilebilir. 


\section{KAYNAKÇA}

AKAR, İbrahim: “Tahrikçi Ajan”, Marmara Üniversitesi Hukuk Araştırmaları Dergisi, 2018, Cilt 24, Sayı 1, s. 132-148.

AKKAYA, Çetin: Uyuşturucu ve Uyarıcı Madde Suçları, 2. Baskı, Adalet Yayınevi, Ankara, 2013.

ALACAKAPTAN, Uğur: İşlenemez Suç, Ankara Üniversitesi Hukuk Fakültesi Yayınları, Ankara, 1968.

ARSLAN, Mehmet: Alman Ceza Hukukunda Suç ve Terör Örgütleriyle Bağlantıll Suçlar ve İştirak Hükümleriyle İlişkileri, Adalet Yayınevi, Ankara, 2020.

ARTUK, Mehmet Emin / GÖKÇEN, Ahmet / ALŞAHIN, M. Emin / ÇAKIR, Kerim: Ceza Hukuku Genel Hükümler, 11. Baskı, Adalet Yayınevi, Ankara, 2017.

AY DIN, Devrim: Türk Ceza Hukukunda Suça İştirak, Yetkin Yayınları, Ankara, 2009.

CENTEL, Nur / ZAFER, Hamide / ÇAKMUT, Özlem: Türk Ceza Hukukuna Giriş, 7. Bası, Beta Yayınevi, İstanbul, 2011.

ÇELEN, Ömer: Bir İştirak Şekli Olarak Yardım Etme (Asli Fail- Yardım Eden Ayrımı), Adalet Yayınevi, Anka ra, 2020.

DEMİRBAŞ, Timur: Ceza Hukuku Genel Hükümler, 8. Baskı, Seçkin Yayınevi, Ankara, 2012.

DEMİREL, Muhammed: "Alman ve Türk Mahkeme Kararlarında Suçun İşlendiği Yerde Bulunmanın İştirak Açısından Niteliği”, Marmara Üniversitesi Hukuk Fakültesi Hukuk Araştırmaları Dergisi, 2019, Cilt 25, Say1 2, Prof. Dr. Ferit Hakan Baykal Armağanı, s. 682-696.

DEMIREL, Muhammed: Suça İştirakte Bağlllık Kuralı, On İki Levha Yayıncılık, İstanbul, 2017 (Bağlılık Kuralı).

DÖNMEZER, Sulhi / ERMAN, Sahir: Nazari ve Tatbiki Ceza Hukuku, Cilt II, 14. Bası, Der Yayınları, İstanbul, 2019.

DÜLGER, İbrahim: "Uyuşturucu veya Uyarıcı Madde İmal ve Ticareti (TCK m. 188)", (Ed.) ÜNVER, Yener / ÖZ, Kerem: Uyuşturucu Madde Suçlartyla Mücadele, Seçkin Yayınevi, Ankara, 2018.

EKICİ ŞAHIN, Meral: "İștirak Halinde İşlenen Suçlarda Suça Etki Eden Nedenlerin Şeriklere Sirayeti”, Ankara Üniversitesi Hukuk Fakültesi Dergisi, 2015, Cilt 64, Sayı 3, s. 637-686.

ELMAS, Birsen: Uyuşturucu ve Uyarıcı Madde Suçları, 4. Baskı, Adalet Yayınevi, Ankara, 2020.

ERDEM, Mustafa Ruhan: "Suçu Bildirmeme Suçu (TCK m 278)", Türkiye Barolar Birliği Dergisi, 2009, Sayı 80, s. $105-120$.

EREM, Faruk / DANIŞMAN, Ahmet / ARTUK, Mehmet Emin: Türk Ceza Hukuku Genel Hükümler, 14. Baskı, Seçkin Yayınevi, Ankara, 1997.

EREM, Faruk: Türk Ceza Kanunu Şerhi Özel Hükümler Cilt: II, Seçkin Yayınevi, Ankara, 1993.

ERMAN, Sahir / ÖZEK, Çetin, Ceza Hukuku Özel Bölüm Kamunun Selametine Karşı İşlenen Suçlar (TCK 369413), Dünya Yayıncılık, İstanbul, 1995.

EVIK, Vesile Sonay: Suça İştirakte Yardım Edenin Cezai Sorumluluğu, On İki Levha Yayıncılık, İstanbul, 2010.

GÜLŞEN, Recep: Ceza Hukukunda Sorumluluğu Kaldıran Nedenlerden Kaza, Mücbir Sebep, Cebir ve Tehdit, Seçkin Yayınevi, Ankara, 2007.

GÜNAL, Yılmaz: Uyuşturucu Madde Suçları, İş Matbaacılık ve Ticaret, Ankara, 1976.

GÜNGÖR, Şener / KINACI, Ali: Öğreti ve Uygulama Boyutu ile Uyuşturucu ve Psikotrop Maddelerle İlgili Suçlar, Yetkin Yayınları, Ankara, 2001.

HAFIZOĞULLARI, Zeki / ÖZEN, Muharrem: Türk Ceza Hukuku Genel Hükümler, 10. Baskı, US-A Yayıncılık, Ankara, 2017 (Genel Hükümler). 
HAFIZOĞULLARI, Zeki / ÖZEN, Muharrem: Türk Ceza Hukuku Özel Hükümler Topluma Karşı Suçlar, 3. Bask1, US-A Yayıncılık, Ankara, 2017 (Topluma Karşı Suçlar).

HAKERİ, Hakan, Ceza Hukuku Genel Hükümler, 19. Baskı, Adalet Yayınevi, Ankara, 2016 (Genel Hükümler).

HAKERI, Hakan: "Yeni Türk Ceza Kanunu'nda İştirak”, Ceza Hukuku Dergisi, 2006, Cilt 1, Sayı 1, s. 75-109 (İștirak).

HEINRICH, Bernd: Ceza Hukuku Genel Kısım II, (Ed.) ÜNVER, Y ener, Adalet Yayınevi, Ankara, 2015.

HILGENDORF, Eric / VALERIUS, Brian: Alman Ceza Hukuku Genel Kisım, (Çev.) OKTAR, Salih, Yetkin Yayınları, Ankara, 2021.

İÇEL, Kayıhan: Ceza Hukuku Genel Hükümler, Beta Yayınevi, İstanbul, 2016.

İLTAȘ, Yiğit: Uyuşturucu veya Uyarıcı Madde Imal ve Ticareti Suçu, Adalet Yayınevi, Ankara, 2020.

JESCHECK, Hans-Heinrich: Alman Ceza Hukukuna Giriş, (Çev.) YENISEY, Feridun, Beta Yayınevi, İstanbul, 2007.

KANGAL, Zeyne: Ceza Hukukunda Zorunluluk Durumu, Seçkin Yayınevi, Ankara, 2010.

KIDIL, Fahrettin: Türk Ceza Hukukunda Uyuşturucu veya Uyarıcı Madde İmal ve Ticareti Suçları, Adalet Ya yınevi, Ankara, 2020.

KURT YÜCEKUL, Gülşah: “Türk Ceza Kanunu'nun 220/4. Maddesinin, Bileșik Suçu Düzenleyen 42. Madde Karşısında Uygulanabilirliği Üzerine Bir Değerlendirme”, Galatasaray Üniversitesi Hukuk Fakültesi Dergisi, 2010, Cilt2, Say1 1, Prof. Dr. Köksal Bayraktar’a Armağan, s. 1027-1033.

ÖNDER, Ayhan: Ceza Hukuku Genel Hükümler Cilt II-III, 2. Bası, Beta Yayınevi, İstanbul, 1992.

ÖNER, Mehmet Zülfü: Türk Ceza Hukukunda Uyuşturucu veya Uyarıcı Madde İmal ve Ticareti Suçları, Adalet Yayınevi, Ankara, 2011

ÖZBEK, Veli Özer / DOĞAN, Koray / BACAKSIZ, Pınar: Türk Ceza Hukuku Genel Hükümler, 10. Baskı, Seçkin Yayınevi, Ankara, 2019.

ÖZBEK, Veli Özer / DOĞAN, Koray / BACAKSIZ, Pınar / TEPE, İlker: Türk Ceza Hukuku Özel Hükümler, 13. Baskı, Seçkin Yayınevi, Ankara, 2018.

ÖZTÜRK, Bahri / ERDEM, Mustafa Ruhan: Uygulamalı Ceza Hukuku ve Güvenlik Tedbirleri Hukuku, 13. Baskı, Seçkin Yayınevi, Ankara, 2013.

ÖZDABAKOĞLU, Erdinç Hakan: 5237 Sayılı Türk Ceza Kanunu'nda Uyuşturucu veya Uyarıcı Madde Suçları ve Ilgili Mevzuat, Adalet Yayınevi, Ankara, 2007.

PARLAR, Ali / KIZILKAYA, Azmi: Uyuşturucu ve Uyarıcı Madde Suçları, Bilge Yayınevi, Ankara, 2018.

PINARCI, Mustafa: Uyuşturucu Sorunu ve Mücadele Politikası, Adalet Yayınevi, Ankara, 2014.

PISAPIA, Gian Domenico: İtalyan Ceza Hukuku Müesseseleri Genel Kısım, (Çev.) AKGÜÇ, Atıf, Adalet Bakanlığı Yayınları, Ankara, 1971.

SELBES, Ece: Uyuşturucu veya Uyarıcı Madde Imal ve Ticareti Suçu, Adalet Yayınevi, Ankara, 2017.

SEVDIM, Ali Erdem: Uyuşturucu veya Uyarıcı Madde Imal ve Ticareti Suçu, Seçkin Yayınevi, Ankara, 2014.

SOYASLAN, Doğan: Ceza Hukuku Genel Hükümler, 7. Baskı, Yetkin Yayınları, Ankara, 2016 (Genel Hükümler).

SOY ASLAN, Doğan: Ceza Hukuku Özel Hükümler, 13. Baskı, Yetkin Yayınları, Ankara, 2020 (Özel Hükümler).

TEKIN, Nurullah: "Uyuşturucu veya Uyarıcı Madde İmal, İthal ve İhraç Etmek ile Satmak, Satın Almak, Kabul Etmek ve Bulundurmak Suçları”, Terazi Hukuk Dergisi, 2009, Cilt 4, Sayı 37, s. 95-110.

TANER, Tahir: Ceza Hukuku Umumi Kısım, 3. Basım, İsmail Akgün Matbaası, İstanbul, 1953.

TAŞKIN KAPUSUZOĞLU, Beril: Suça İştirakte Bağlllık Kuralı, On İki Levha Yayıncılık, İstanbul, 2017. 
TAŞKIN, Ozan Ercan: Klşkırtıcı Ajan, Seçkin Yayınevi, Ankara, 2011.

TEZCAN, Durmuş / ERDEM, Mustafa Ruhan / ÖNOK, R. Murat: Teorik ve Pratik Ceza Özel Hukuku, 17. Bask1, Seçkin Yayınevi, Ankara, 2019 (Ceza Özel Hukuku).

TEZCAN, Durmuş / ERDEM, Mustafa Ruhan / ÖNOK, Murat: Uluslararası Ceza Hukuku, 3. Baskı, Seçkin Yayınevi, Ankara, 2015 (Uluslararası Ceza).

TONGÜR, Ali Rıza / ÇETINTÜRK, Ekrem: Ceza Hukuku Genel Hükümler, Adalet Yayınevi, Ankara, 2020.

TOROSLU, Nevzat: Ceza Hukuku Genel Kısım, 18. Baskı, Savaş Yayınevi, Ankara, 2012.

ÜNVER, Yener: "Karşılaştırmalı Hukukta Uyuşturucu Maddeler Konusunda Önemli Hukuki Düzenlemeler”, (Ed.) ÜNVER, Yener / ÖZ, Kerem Uyuşturucu Madde Suçlarıyla Mücadele, Seçkin Yayınevi, Ankara, 2018.

YALÇIN SANCAR, Türkan: Çok Failli Suçlar, Seçkin Yayınevi, Ankara, 1998.

YAŞAR, Osman / GÖKCAN, Hasan Tahsin / ARTUÇ, Mustafa: Yorumlu-Uygulamalı Türk Ceza Kanunu 4. Cilt md. 141-196, 2. Baskı, Adalet Yayınevi, Ankara, 2014.

YENISEY, Feridun / PLAGEMANN, Gottfried: 15 Mayls 1871 tarihli Alman Ceza Kanunu, Beta Yayınevi, İstanbul, 2009.

YOKUŞ SEVÜK, Handan: Türk Ceza Hukuku Özel Hükümler, 2. Baskı, Adalet Yayınevi, Ankara, 2019 (Özd Hükümler).

YOKUŞ SEVÜK, Handan: Uyuşturucu veya Uyarıcı Madde Kullanılmasına İlişkin Suçlar, Seçkin Yayınevi, Ankara, 2007 (Uyuşturucu veya Uyarıcı Madde Kullanılmasına İlişkin).

YÜCE, Turhan Tufan: Ceza Hukukunun Temel Kavramları, Turhan Kitabevi, Ankara, 1985.

YOLCU, Ferit: Uyuşturucu veya Uyarıcı Madde Imal ve Ticareti Suçu (TCK m. 188), Adalet Yayınevi, Ankara, 2015.

ZAFER, Hamide: Ceza Hukuku Genel Hükümler TCK m. 1-75, 4. Bası, Beta Yayınevi, İstanbul, 2015. 